\title{
St. Vincent and the Grenadines: 2007 Article IV Consultation-Staff Report; Staff Supplement and Statement; Public Information Notice on the Executive Board Discussion; and Statement by the Executive Director for St. Vincent and the Grenadines
}

Under Article IV of the IMF's Articles of Agreement, the IMF holds bilateral discussions with members, usually every year. In the context of the 2007 Article IV consultation with St. Vincent and the Grenadines, the following documents have been released and are included in this package:

- $\quad$ The staff report for the 2007 Article IV consultation, prepared by a staff team of the IMF, following discussions that ended on November 9, 2007, with the officials of St. Vincent and the Grenadines on economic developments and policies. Based on information available at the time of these discussions, the staff report was completed on January 7, 2008. The views expressed in the staff report are those of the staff team and do not necessarily reflect the views of the Executive Board of the IMF.

- $\quad$ A staff supplement on the joint IMF/World Bank debt sustainability analysis.

- A staff statement of February 4, 2008, updating information on recent developments.

- $\quad$ A Public Information Notice (PIN) summarizing the views of the Executive Board as expressed during its February 4, 2008 discussion of the staff report that concluded the Article IV consultation.

- $\quad$ A statement by the Executive Director for St. Vincent and the Grenadines.

The document listed below has been or will be separately released.

Statistical Appendix

The policy of publication of staff reports and other documents allows for the deletion of market-sensitive information.

Copies of this report are available to the public from

International Monetary Fund • Publication Services

$70019^{\text {th }}$ Street, N.W. • Washington, D.C. 20431

Telephone: (202) 623-7430 • Telefax: (202) 623-7201

E-mail: publications@imf.org • Internet: http://www.imf.org

\section{International Monetary Fund Washington, D.C.}



INTERNATIONAL MONETARY FUND

ST. VINCENT AND THE GRENADINES

Staff Report for the 2007 Article IV Consultation

Prepared by the Staff Representatives for the 2007 Consultation with

St. Vincent and the Grenadines

Approved by Markus Rodlauer and Matthew Fisher

January 7, 2008

\section{EXECUTIVE SUMMARY}

Background: Output grew at nearly 7 percent in 2006, the highest in a decade, and is expected to remain close to that in 2007. Despite a recent debt write-off public debt remains high at 68 percent of GDP at end-2007, limiting the room for needed poverty-alleviating and social sector spending.

Although external competitiveness remains a challenge, the real effective exchange rate is broadly in line with fundamentals. Current account deficits are projected to remain elevated, reflecting expanding tourism capacity and new infrastructure projects, but are expected to taper off as these activities decline.

\section{Discussions focused on the key policy issues:}

- Raising growth prospects: The central challenge is to develop and diversify the tourist industry, by overcoming impediments including limited air transportation links, without jeopardizing debt sustainability. The planned construction of a new airport should be financed as much as possible from concessional sources; the authorities explained that any commercial borrowing for the project would only be of a bridge financing nature while the sale of state-owned land takes place. Other requirements for growth include sustained structural reforms to broaden the economic base, and steps to improve the investment climate.

- Ensuring fiscal and debt sustainability: The rebound in growth and the debt write-off provide an opportunity to continue with fiscal consolidation and put debt on a solid downward path. Key to this end will be maintaining the integrity of the value-added tax (VAT), better prioritizing capital expenditure, adjusting domestic fuel prices, and reforming the National Insurance Service (NIS) and public service pensions. Success in these areas should also provide scope to meet priority needs for education, health and infrastructure spending.

- Reducing vulnerabilities: The authorities have taken steps to strengthen disaster preparedness, strengthen financial sector supervision and respond to the economic and social impact of continued erosion of European Union trade preferences. Establishing a single regulatory unit for supervising nonbank financial institutions is a priority. 


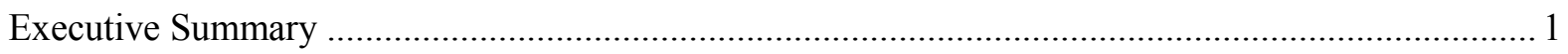

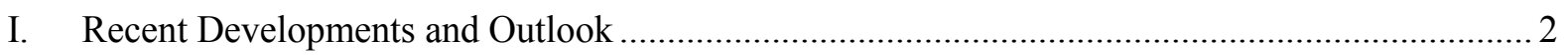

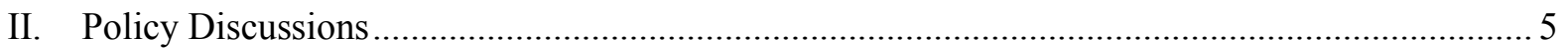

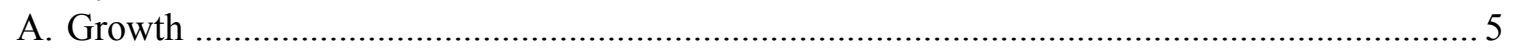

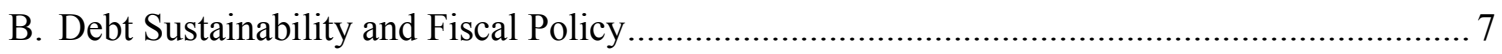

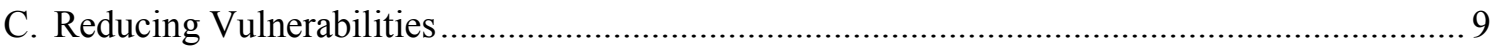

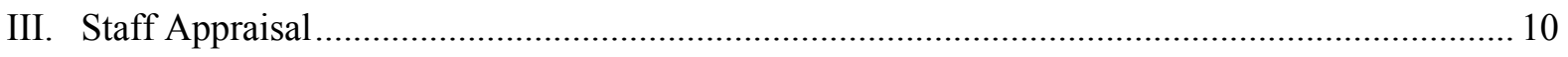

Boxes

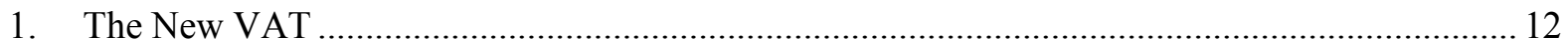

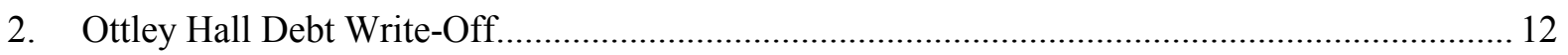

3. Challenges Facing the National Insurance Services (NIS) and Public

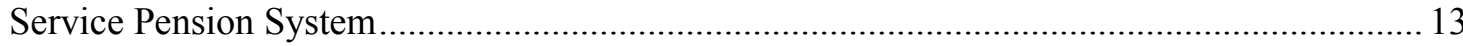

Figures

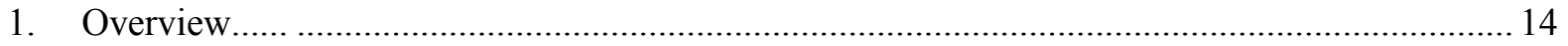

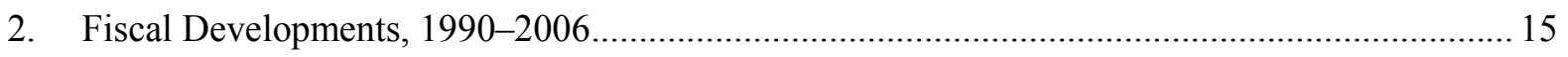

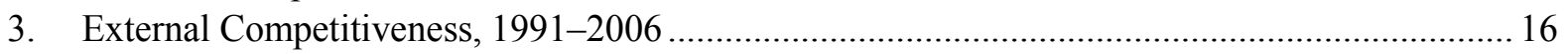

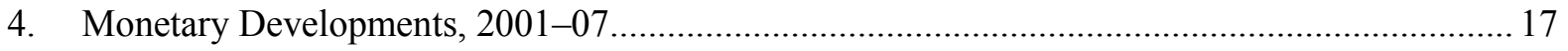

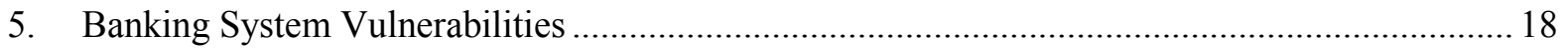

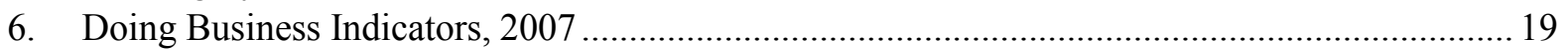

Tables

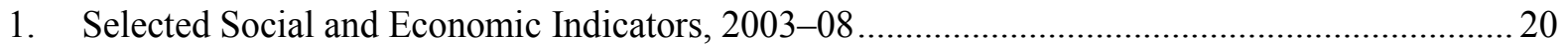

2a. Summary of Central Government Operations, 2003-12 (in millions of EC dollars) .................. 21

2b. Summary of Central Government Operations, 2003-12 (in millions of EC dollars) .................. 22

3a. Summary of Central Government Operations, 2003-12 (in percent of GDP) .......................... 23

3b. Summary of Central Government Operations 2003-12 (in percent of GDP) ............................ 24

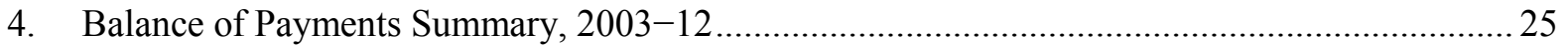

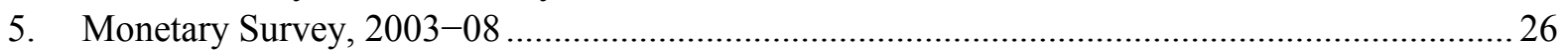

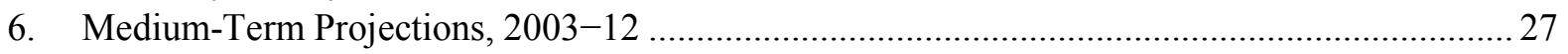

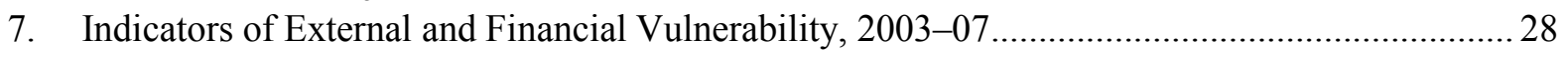

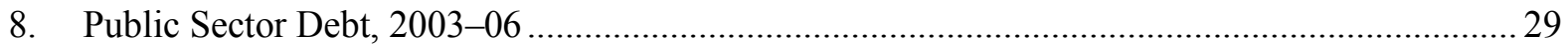

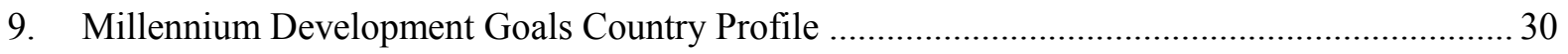

Annexes

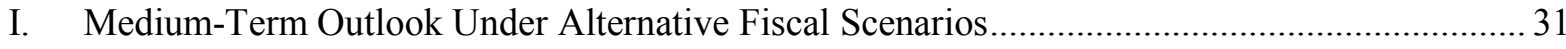

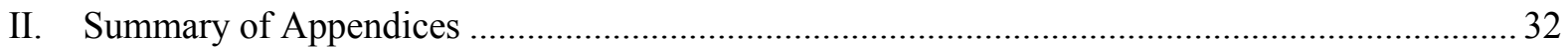

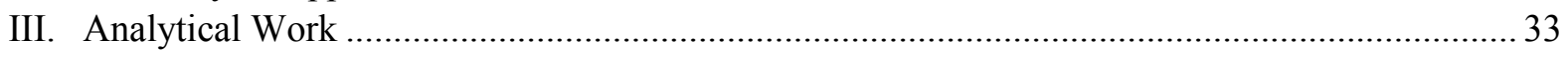




\section{RECENT DEVELOPMENTS AND OUTLOOK ${ }^{1}$}

1. The economy is enjoying its second year of vigorous economic growth.

- Output grew at close to

7 percent in 2006, the highest

in the last decade and well

above potential (estimated at $4 \frac{1}{4}$ percent). Economic activity was sustained by construction and government services. In 2007 growth is expected to remain strong, despite disappointing tourism arrivals, due largely to tourism-related investments and government capital expenditure. $^{2}$

\begin{tabular}{|c|c|c|c|c|c|c|c|}
\hline & 2003 & 2004 & 2005 & 2006 & $\begin{array}{l}\text { Proj. } \\
2007\end{array}$ & $\begin{array}{l}\text { Baseline } \\
2008\end{array}$ & $\begin{array}{r}\text { Active } \\
2008\end{array}$ \\
\hline & \multicolumn{7}{|c|}{ (Percentage change) } \\
\hline Real GDP & 2.8 & 6.8 & 2.6 & 6.9 & 6.7 & 5.0 & 5.4 \\
\hline CPI, end of year & 2.7 & 1.7 & 3.9 & 4.8 & 8.2 & 3.6 & 3.6 \\
\hline $\begin{array}{l}\text { Real effective exchange rate } \\
\text { (depreciation -) }\end{array}$ & -7.3 & -3.6 & 0.1 & -0.6 & $\ldots$ & $\ldots$ & $\ldots$ \\
\hline Credit to private sector & 0.6 & 0.9 & 5.5 & 14.3 & 15.8 & 8.0 & 8.8 \\
\hline \multirow[t]{2}{*}{ Stay-over arrivals } & 1.2 & 10.4 & 9.5 & 2.6 & 0.0 & 5.0 & 5.0 \\
\hline & \multicolumn{7}{|c|}{ (In percent of GDP) } \\
\hline Central government balance & -3.3 & -3.5 & -5.5 & -4.9 & -4.2 & -3.4 & -2.1 \\
\hline Central government primary balance & -0.6 & -1.1 & -2.5 & -1.7 & -0.7 & 0.7 & 1.9 \\
\hline External current account balance & -20.8 & -24.8 & -22.7 & -24.4 & -26.9 & -26.8 & -26.9 \\
\hline
\end{tabular}

Sources: Ministry of Finance and Planning; and Fund staff estimates and projections.

- Inflation has risen, mainly due to higher international oil and food prices, and is expected to reach 8.2 percent by end-2007. The introduction of the VAT in May 2007 had a oneoff effect on inflation.

- The current account deficit is expected to remain high in 2007-08 on account of higher imports for various tourism-related projects and capital spending by the government.

- Credit to the private sector expanded by $14 \frac{1}{4}$ percent in 2006, attributable to the Cricket World Cup (CWC) and tourism-related activities. In 2007-08 private credit growth is expected to remain strong given the tourism-related activities and the construction boom in the private sector.

- Financial sector indicators have strengthened, but balance sheet vulnerabilities remain. While asset quality and capital adequacy have improved, provisioning by foreign banks continues to decline. Unsatisfactory assets (NPLs) have declined to 3 percent of total

\footnotetext{
${ }^{1}$ A staff team comprising Ms. Pattillo (Head), Mr. Pineda, Ms. Tsounta (all WHD), and Ms. Basu (FIN) visited Kingstown during October 25-November 9, 2007. The mission met with the Prime Minister and Minister of Finance, Dr. Ralph Gonsalves, the Director General of the Ministry of Finance, other senior government officials, opposition parliamentarians and political leaders, representatives of the financial and business sectors, and farmers, trade unions and civil society. Staff of the Eastern Caribbean Central Bank (ECCB) and Caribbean Development Bank (CDB) also participated. Messrs. Cashin (WHD) and Charleton (OED) joined the mission for the final discussions, which overlapped with the Eastern Caribbean Currency Union (ECCU) Regional Discussions.

${ }^{2}$ Tourism arrivals fell by 14 percent in the first seven months of 2007, driven by a sharp decline in intraCaribbean arrivals (probably related to the increase in airfares following the merger of two regional airlines).
} 
loans, well below the ECCB's target of 5 percent. Increasing competition from nonbank financial institutions and recent rapid credit growth could result in weaknesses in loan classification and problem loans down the road, especially in the event of a large adverse shock. An update of a 2004 AML/CFT assessment will take place in early 2009, at the request of the authorities.

- The outlook remains favorable. In 2008 growth is expected to remain strong with the construction of the international airport, while inflation is expected to moderate due to the projected stabilization of international oil and food prices. There are risks, however, as the turbulence in global financial markets may dampen tourism demand and FDI flows.

2. The fiscal position has strengthened. The primary deficit has narrowed by around 2 percent of GDP during 2005-07 reflecting both higher revenues and current spending restraint. Revenues benefited from the growth dividend (higher stamp taxes related to land sales), more frequent pass-through of oil prices, as well as the introduction of a VAT in May 2007 (Box 1). Wage restraint helped contain spending despite an increase in capital expenditure.

3. An agreement with Italy to write-off the Ottley Hall debt obligation has reduced St. Vincent and the Grenadines' public debt stock by about 10 percent of GDP. The loan had been serviced by the Italian export agency, due to perceived malfeasance by the private builder-operator. The write-off, formalized in October 2007, will lower the debt to-GDP ratio to around 68 percent by end-2007 (Box 2).

\section{Although external competitiveness remains a challenge, the exchange rate does} not appear to be overvalued. At end-September 2007 the real effective exchange rate (REER) was at its lowest level in nearly 20 years, reflecting the depreciation of the U.S. dollar against major currencies. Staff analysis finds that the REER is currently around its estimated equilibrium level. ${ }^{3}$ External debt ratios, while among the lowest in the region, are still high, and thus fiscal consolidation is needed to maintain competitiveness and enhance debt sustainability.

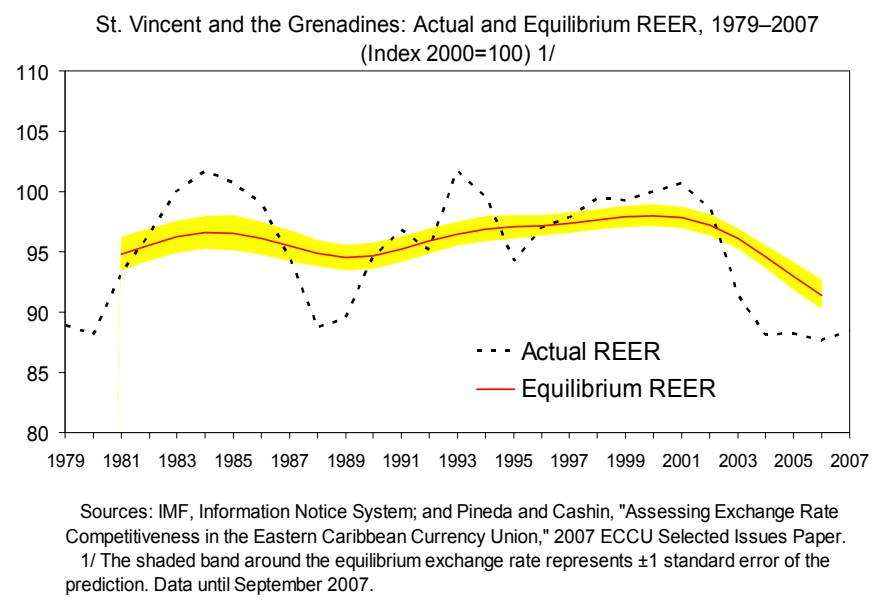

\footnotetext{
${ }^{3}$ A time series model linking the REER to measures of the ECCU region's fundamentals (productivity differentials, terms of trade, government consumption and net foreign assets) indicates that there is little evidence of overvaluation of the EC dollar. See Pineda and Cashin (2007), "Assessing Exchange Rate Competitiveness in the Eastern Caribbean Currency Union," 2007 ECCU Selected Issues Paper.
} 
However, even under a current-policies scenario, the projected debt profile would not seem to endanger the stability of the region's currency board arrangement.

5. Current account deficits are projected to remain elevated, as St. Vincent and the Grenadines continues to adjust from an agricultural to a tourism-based economy. The recent increase in current account deficits reflects, in large part, preparations for the CWC and expanding tourism capacity as the country develops its tourism sector. The size of future current account imbalances is expected to taper off in line with the decline in the construction of new infrastructure projects and new resort facilities, though to remain elevated in the projection period. This implies that despite their high levels, current account deficits, financed largely by FDI, appear sustainable. An abrupt shift in investor sentiment that reduces private investment in the tourist sector would be associated with a corresponding decline in imports, with only limited disruption in the domestic economy.

\section{Policy Discussions ${ }^{4}$}

6. The discussions focused on policies to enhance the economy's growth potential and reduce poverty, strengthen debt sustainability and address vulnerabilities.

\section{A. Growth}

7. Enhancing growth prospects will be a challenge. Further developing and diversifying the tourist industry will require overcoming impediments, including limited international air transportation links. Structural reforms should aim at broadening the economic base and creating an environment where the private sector is the engine of growth. This could involve rethinking the need for state ownership in particular sectors, and working with the World Bank and other donors to implement a private sector development program.

- Tourism and international air transportation. Although the tourist industry will need better air transport links, staff expressed concern over the expected impact of the international airport project on the country's debt position. Identified grant and concessional financing (mostly in-kind from Venezuela and Cuba) falls

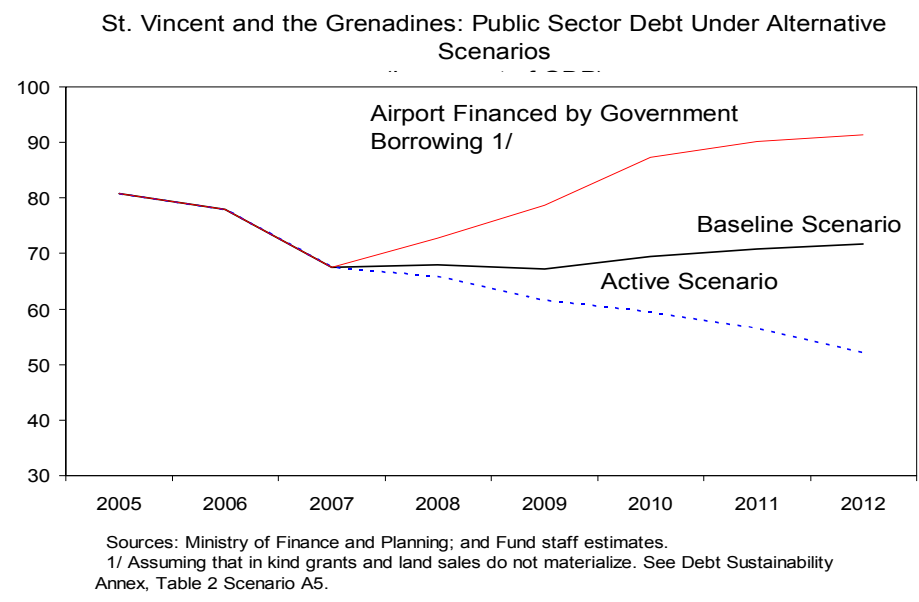

\footnotetext{
${ }^{4}$ The discussions were complemented by the 2007 ECCU Regional Discussions, the report for which covers common regional issues.
} 
short of requirements by around EC $\$ 150$ million (around 10 percent GDP). ${ }^{5}$ While the government initially expected to finance most of this gap through land sales, this may not be feasible within the next five years because most of the land still needs to be developed. If the gap were to be filled by commercial borrowing, debt would increase to around 72 percent of GDP by 2012, and possibly higher if in-kind grants do not materialize. Staff recommended an updated study of financing options for the project. The authorities should also make sure that all infrastructure spending, operational costs, and borrowing related to the project are carefully planned and transparently budgeted and accounted for, possibly in the context of a medium-term expenditure framework. The authorities underscored that the airport would not have an impact on the medium-term debt position, since any borrowing would be of a bridge financing nature until the sale of state-owned land takes place.

- The investment climate. Private domestic investment has stagnated in recent years, mainly as a result of high real interest rates, the lack of equity finance, and an unfavorable tax regime. ${ }^{6}$ The World Bank's Doing Business Indicators suggest improvements are needed in areas such as registering property, contract enforcement, closing a business, availability of credit information, and cost of importing. Staff also recommended a more transparent framework for providing tax incentives that more effectively favors new investment, possibly involving accelerated depreciation and loss carry-forward provisions. This could support further lowering of the corporate income tax rate, as planned by the authorities.

- Leveraging remittances. More than a quarter of the labor force of St. Vincent and the Grenadines emigrated to OECD countries in the period 1970-2000, producing a steady flow of remittances. Staff supported the authorities' plans to boost the growth impact of remittances, for example, through financial literacy programs geared toward more efficient and productive use of remittances.

- International trade. St. Vincent and the Grenadines still has licensing requirements for some items (mainly agricultural and manufactured products). Staff encouraged tarification of all items in line with WTO requirements. A draft National Export Strategy will set out priority export areas, including tourism and agribusiness.

\footnotetext{
${ }^{5}$ The construction of the international airport at Argyle is expected to cost around EC $\$ 480$ million (around 32 percent of GDP) and be completed by 2012 .

${ }^{6}$ See Roache (2006), "Domestic Investment and the Cost of Capital in the Caribbean," IMF Working Paper 06/152.
} 


\section{B. Debt Sustainability and Fiscal Policy}

8. Public debt needs to be reduced further. While the Ottley Hall debt write-off will help the debt dynamics, it will not improve cashflow as the debt had been serviced by the Italian export guarantee agency. Debt service already consumes $22 \frac{1}{2} 2$ percent of revenues, more than spending on health and education. ${ }^{?}$

\section{Sustained fiscal consolidation will create room for the government's goal to raise} social spending. Staff

recommended fiscal measures that would result in a primary surplus of around 4 percent of GDP by 2012. Together with the additional tax yield expected from the VAT (1.5 percent of GDP), a package of measures, including continued moderation in the wage bill and prioritization of capital spending, would lead to a central government primary surplus of around 2 percent of GDP in 2008. In 2009, continued wage and capital expenditure restraint, and a new market-based property tax would increase the primary surplus to around 3 percent of GDP. In the medium term, continuation of these policies would bring the debt down to below 60 percent of GDP (the ECCB's benchmark) by 2011 (See Annex I and the companion Debt

St. Vincent and the Grenadines: Public Sector Debt Dynamics (In percent of GDP)
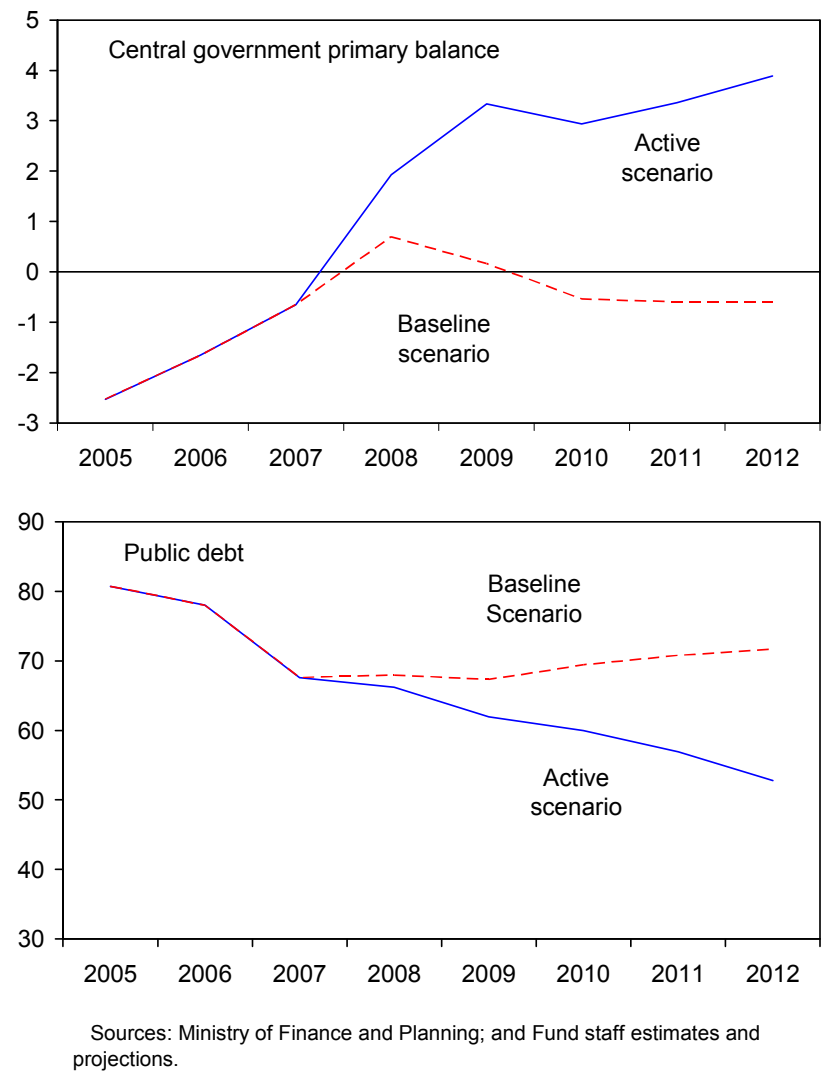
Sustainability Analysis paper).

- $\quad$ Property tax. The real estate sector is performing well, but with little improvement in property tax collections. The authorities plan to move to a market valuation-based property tax system as soon as technically feasible.

- Tax concessions. The Custom and Revenue Department estimates that customsrelated exemptions cost about 9 percent of GDP in 2006 alone. Staff encouraged the

\footnotetext{
${ }^{7}$ In December 2007 Moody's Investors Service assigned a B1 long-term foreign and local-issuer rating with a stable outlook to St. Vincent and the Grenadines, noting that further reductions in the debt-to-GDP ratio would be necessary for the rating to improve.
} 
authorities to phase out discretionary import and corporate tax concessions, replace the latter with accelerated depreciation and loss carry forward provision, and gradually lower the top corporate tax rate from 37.5 percent to 30 percent. The annual budget should clearly specify revenue losses from exemptions and concessions.

- $\quad$ Taxation of petroleum products. Although retail prices have been adjusted more frequently in 2006 and 2007, staff recommended an automatic adjustment mechanism to minimize revenue losses due to delays in adjustment, increase transparency and reduce the political costs associated with announcing price hikes.

- International airport. The authorities expect to borrow domestically EC $\$ 40$ million in 2008 (following borrowing of EC \$50 million in 2006-07) as bridge-financing until land sales materialize. Staff urged the authorities to review carefully the financing of the project, seek additional grant and concessional financing, and make sure land sales are realized as planned.

- Capital budget. Better prioritization of capital expenditures would enhance their efficiency and contribution to growth. Staff recommended that the government use World Bank expertise to evaluate all public sector investment program (PSIP) projects above a certain threshold (e.g., EC\$5 million). Upgrading the PSIP with technical assistance from the Caribbean Development Bank (CDB) and CARTAC is also recommended.

- $\quad$ Public sector wages. The government's wage bill, which accounts for about half of all current expenditures, is among the highest in the ECCU despite its recent reduction. Prudent management of wage increases and payrolls is needed. The recent job reclassification exercise of civil servants should be used as a first step to wider public service reform aimed at reducing employment levels, providing greater differentiation in the pay scale and improving the overall delivery of public services.

10. Staff commended the authorities on the successful introduction of the VAT and urged them to hold firm against pressures to change rates and the exemption structure. The number of taxpayers registering for the VAT has exceeded the authorities' original expectation by about half, with most taxpayers filing returns on time. The main challenge now is to strengthen audit efforts, and to maintain the integrity of the VAT against pressures to change the rate structure and increase the list of exempted and zero-rated items. 


\section{Fiscal risks associated with the NIS should be addressed and social programs} better targeted:

- $\quad$ Social security and public service pension reform. Staff supports the authorities' intention to reform the NIS including through some combination of gradual increases in the contribution rate and in the retirement age, and a reduction in the average replacement rate. Staff also encouraged the authorities to rationalize the public pension

St. Vincent and the Grenadines: Pension Contributions and Expenditures (In percent of GDP)

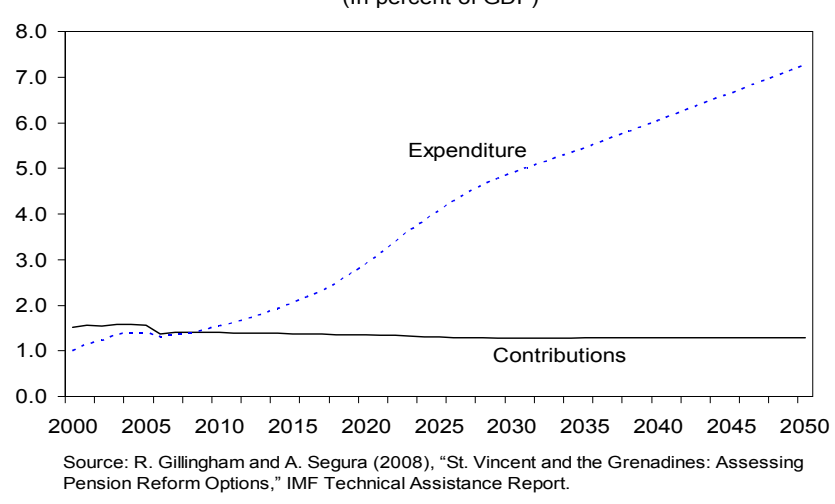
system by integrating it with the NIS (Box 3).

- Social programs. A series of social programs has evolved in a piecemeal fashion, which is both expensive and inefficient in targeting the needs of vulnerable groups. An ongoing household survey and poverty assessment, due by end-2008, should be used to construct a well-targeted system with clear criteria. This could yield substantial savings and help strengthen the impact of social programs, including universal secondary education and newly announced health initiatives.

\section{Reducing Vulnerabilities}

12. The medium-term growth outlook appears favorable, but is subject to risks because of the economy's high vulnerability to exogenous shocks.

- $\quad$ Financial sector soundness. The mission welcomes the 2006 passage of amendments to the uniform Banking Act-bolstering ECCB regulatory powers and requiring banks to provision for nonperforming government loans - and other improvements to prudential regulations. Priorities going forward include further strengthening of onsite and offsite examinations, establishing a single regulatory unit for nonbanks, and enhancing supervisory capacity for all offshore financial entities. The latter is important as the authorities view the offshore sector as a critical growth area and plan to enhance their capacity to market and support the industry. Establishment of a credit bureau would also support the continued expansion of sound credit flows.

- International financial turbulence. While past international financial crises had little impact on ECCU domestic credit markets, the ongoing repricing of risk could potentially increase rollover risks should there be a continuous tightening of global 
liquidity conditions. ${ }^{8}$ Moreover, lower growth and consumption in North America and Europe could slow tourism demand and FDI.

- $\quad$ Natural disasters. St. Vincent and the Grenadines is one of the world's most disaster-prone countries, and its participation in the World Bank's Catastrophic Risk Insurance Facility is welcome. Staff commends passage of the Disaster Management Act and the Building Code, and encourages further insurance of public and private assets.

- The banana sector. The EU has committed funds to ameliorate the social impact of the sector's decline, but disbursements have been minimal. ${ }^{9}$ The authorities pointed to their efforts to speed disbursements of EU commitments through contracting a Food and Agriculture Organization (FAO) group as the implementing agency, and their request to transform all EU commitments into budgetary support. Staff supported a variety of targeted transition measures such as income transfers and noncontributory pensions, noting the need for a transparent mechanism to fund these programs.

\section{STAFf APPRAisal}

\section{Growth has strengthened in recent years, providing an opportunity for} deepening the reform effort. Activity is being driven by expansion in construction and tourism capacity, which should also support favorable prospects going forward. However, sustaining high growth will be a challenge requiring continued structural reforms to broaden the economic base, and enhance the investment climate.

14. Developing the tourist industry will require enhancing air transport links, but the potential impact of the international airport project on the country's debt position needs to be considered carefully. As a significant portion of the airport project may need to be financed with commercial borrowing, staff urged the authorities to undertake an up-todate study of the financing structure, and make continued efforts to secure grant and concessional loans to meet the projected financing needs in future years of the project.

15. Fiscal consolidation needs to continue. The Ottley Hall debt write-off is welcome. However, debt levels are still high and debt service consumes a considerable part of revenues - more than spending on health and education. Continuing efforts toward fiscal consolidation are needed to improve debt dynamics, increase the fiscal room to address poverty alleviation and social needs and to cope with adverse shocks.

16. The steps taken to improve tax policy and administration, including adoption of the VAT, are welcome. It is crucial, however, that the authorities hold firm against emerging

\footnotetext{
${ }^{8}$ The gross external financing needs of the government in 2008-09 are estimated at around 5 percent of GDP.

${ }^{9}$ Banana exports as a share of GDP are expected to decline from 2.6 percent in 2006 to 1.6 percent in 2012.
} 
pressures to change the VAT rate and exemption structure. Removing discretionary tax concessions would allow space for phased reductions in the corporate income tax, and introduction of a market-based property tax would boost revenues. On the expenditure front priorities include better prioritization and phasing of infrastructure projects, and continued containment in the growth of the wage bill. Together with the additional tax yield expected from the VAT, these measures should allow an improvement in the primary balance of around $2 \frac{1}{2}$ percent of GDP in 2008 .

\section{Staff supports the authorities' intention to reform the NIS and civil service}

pensions. Proposed reforms to ensure NIS's financial viability include gradual increases in the contribution rate and in the retirement age, and a reduction in the average replacement rate. Staff welcomes the authorities' plans to introduce some combination of these parametric reforms. Staff also encourages the authorities to rationalize the public pension system by transforming it into a complement to the NIS.

\section{Although external competitiveness remains a challenge, the real effective} exchange rate is broadly in line with fundamentals. Going forward, fiscal consolidation along with growth enhancing reforms will be needed to support competitiveness and ensure the continued stability of the currency board arrangement. Recent increases in the current account deficit reflect expanding tourism capacity and new infrastructure projects and are expected to taper off as these activities decline. However, even under a current policies scenario, debt accumulation would not seem to endanger stability of the region's currency board arrangement.

19. Further strengthening of financial sector supervision is a priority. Staff welcomes the passage of amendments to the uniform Banking Act and other improvements to prudential regulations. Financial sector supervision should continue to be strengthened, including through effective onsite and offsite examinations and by establishing a single regulatory unit for nonbank financial institutions.

20. Despite significant progress in recent years, St. Vincent and the Grenadines' economy remains vulnerable. Key risks include: the high public debt and potential reversal of debt reduction, the occurrence of natural disasters, lower growth in North America and Europe, rising oil prices, and more rapid erosion of trade preferences for banana exports. The authorities will need to respond rapidly to any changes in the country's economic environment.

21. Despite efforts to enhance statistics, data remains weak in terms of coverage and timeliness. In particular, improvements are needed in the national accounts; fiscal data for public enterprises; and tourism, private sector capital flows, external assets, labor markets, and foreign project aid data.

22. It is recommended that the next Article IV consultation take place on the standard 12-month cycle. 


\section{Box 1. The New VAT}

A new VAT was introduced successfully on May 1, 2007. The introduction was well managed by the authorities and supported by CARTAC assistance. Additional staff were appointed in the Inland Revenue Department (IRD), allowing it and businesses to prepare adequately. The VAT has a rate of 15 percent for goods and services, with a number of basic items zero-rated (such as bulk rice, flour and sugar) or exempted (publicly-supplied water and prescription drugs). Tourist accommodations have a rate of 10 percent.

Preparing the public was key to the success of the launching. Activities included intensified efforts to educate the public, increase the number of taxpayers registered, and assist taxpayers to file. About 73 percent of registered taxpayers initially filed the VAT return on time; with the authorities' follow-up activities, the filing rate for September has risen to about 80 percent.

The main challenges going forward will be to strengthen compliance measures and to maintain the integrity of the VAT. IRD has continued to increase the number of audits conducted, including the first audits in the Grenadines, and has focused on detecting taxpayers preparing VAT invoices and sales receipts that do not meet the minimum requirements. However, no penalties have been assessed and further enforcement steps are necessary to deal with the identified violations. CARTAC short-term experts are providing technical assistance to strengthen audit efforts. Pressures for exemptions and discretionary waivers have increased, particularly in the tourism sector. It is crucial that the authorities withstand those pressures.

Preliminary numbers indicate that the VAT is likely to yield additional revenues of around 0.5 percent of GDP for 2007. Consumption tax revenues through September 2007 grew by around 40 percent compared to a similar period in 2006, consistent with the expected yield for the entire year.

\section{Box 2. Ottley Hall Debt Write-Off}

In 1999 the government assumed a large private external debt of EC\$156 million (171/2 percent of 1999 GDP) for the construction of the Ottley Hall shipyard (a yacht repair facility). The shipyard was operated by a joint-venture company between the government (49 percent) and a private company ( 51 percent). The government had guaranteed the debt. Due to perceived malfeasance by the private partner, the project ended up being a large loss-maker. The government estimates that the value of the assets amount to only about EC\$14 million. In 2001 the government obtained a moratorium on interest payments pending a settlement with creditors (foreign commercial banks), and the Italian export guarantee agency, SACE, which had insured the external creditors, began servicing the loan.

In October 2007 the governments of Italy and St. Vincent and the Grenadines formalized the write-off of the Ottley Hall debt obligation, reducing St. Vincent and the Grenadines' public debt by EC\$150 million, to around 68 percent of GDP. 


\section{Box 3. Challenges Facing the National Insurance Services (NIS) and Public Service Pension System ${ }^{1}$}

The fragile financial position of St. Vincent and the Grenadines' NIS, and the growing demands placed on the budget by the public service (PS) pension system present serious challenges. Although the NIS currently runs a significant cash surplus, population aging, the maturing of the scheme, and its current structure-with a low contribution rate of only 6 percent, a young retirement age of 60 years and replacement rates of up to 60 percent of wages-will require steep increases in contributions in the future. A recent Fiscal Affairs Department (FAD) technical assistance mission found that, without reforms, the trust fund could be exhausted by 2025 and the cumulated deficits grow to 165 percent of GDP by 2050 . The growth in benefits for retired civil servants presents an immediate challenge, with the PS pension bill now accounting for 1.3 percent of GDP — double its 2000 value - and growing at almost twice the rate of the wage bill.

To avoid the need for abrupt and disruptive future adjustments, reform of the NIS should start immediately. Proposals to ensure its financial sustainability, some of which are currently being considered by the authorities, include a gradual increase in the contribution rate and retirement age; and a gradual decline in the replacement rates. Other efficiency and equity-enhancing reforms could include the indexation of pensions to the consumer price index; changing the calculation of survivor benefits to better protect the families of young workers; and placing NIS's investment into an internationally well-diversified portfolio.

Immediate action is also needed to contain the PS pension bill. The system is noncontributory, with pensions more generous than the NIS ones, allowing for retirement at 55 with a maximum replacement rate of $66^{2} / 3$ percent of the employees' three best years. Since civil servants also participate in the NIS scheme, replacement rates could potentially approach 127 percent if employees reach the maximum under both schemes.

The two pension schemes should be integrated. Proposed reforms include capping the PS pension benefits to limit the combined NIS and PS replacement rate below 100 percent; aligning the NIS and PS retirement ages; and instituting a contribution for pensionable workers in the PS system to make full compensation of public servants transparent. To increase social consensus for reforms and enhance equity and efficiency, additional measures could include the provision of survivor benefits and some compensation for those who leave before being eligible for a pension; and closing the PS pension system to new workers while substituting an Individual Retirement Account, with matching employer contributions.

${ }^{1}$ This box draws on R. Gillingham and A. Segura (2008), "St. Vincent and the Grenadines: Assessing Pension Reform Options," IMF Technical Assistance Report. 
Figure 1. St. Vincent and the Grenadines: Overview

Exogenous shocks have contributed to volatile growth.

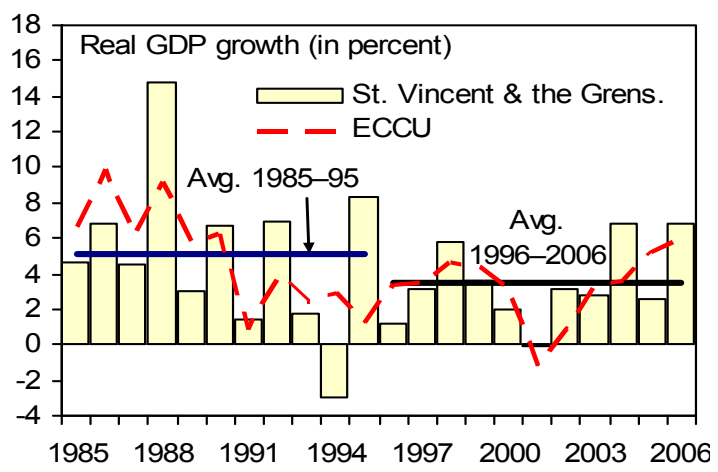

Poverty rates are among the highest in the region...
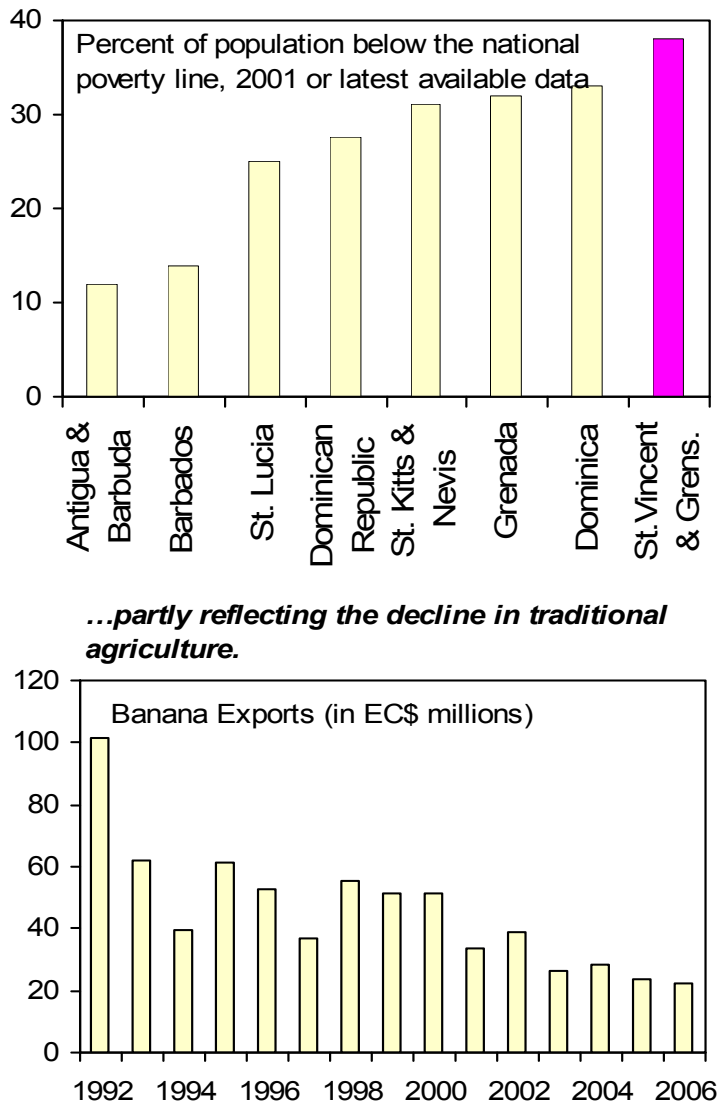

The quasi-currency board arrangement has provided price stability, with inflation anchored around the U.S. level.

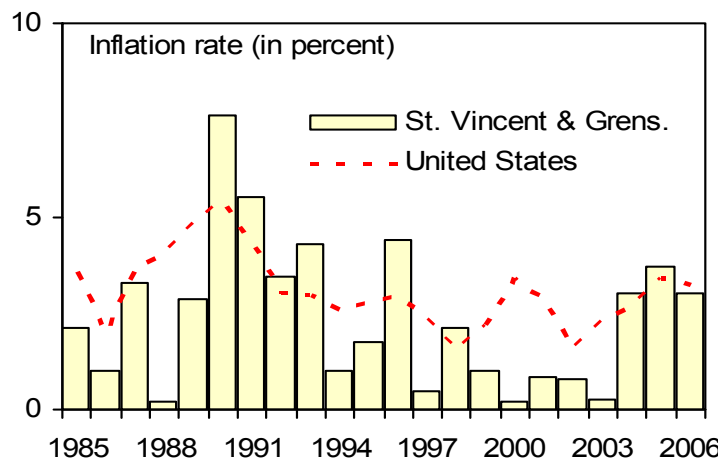

....and so is income inequality...

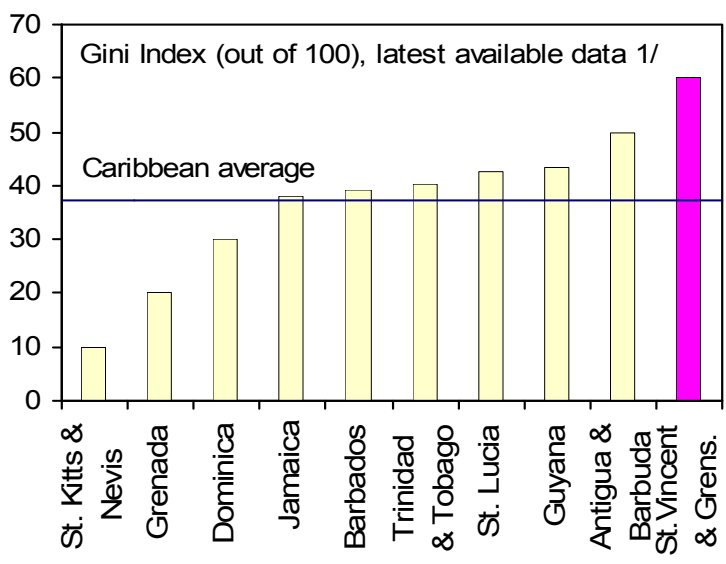

The importance of tourism has been growing.

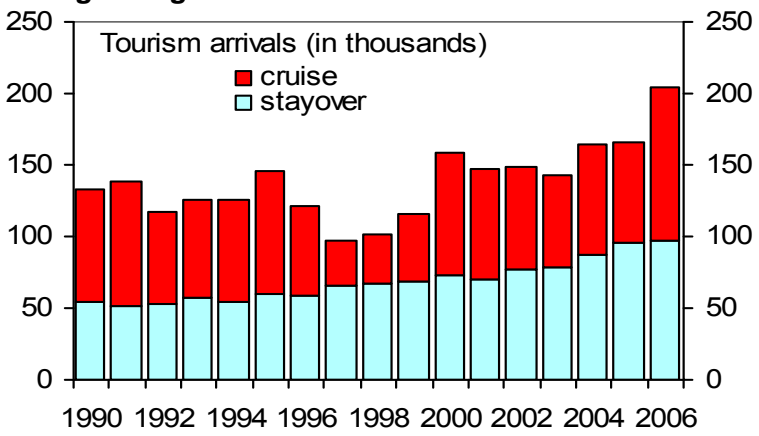

Sources: ECCB; World Bank; and Fund staff estimates. 1/ A larger value indicates greater income inequality. 
Figure 2. St. Vincent and the Grenadines: Fiscal Developments, 1990-2006 (In percent of GDP, unless otherwise denoted)

Expenditures have trended upwards since 1996, while revenues have been relatively flat.

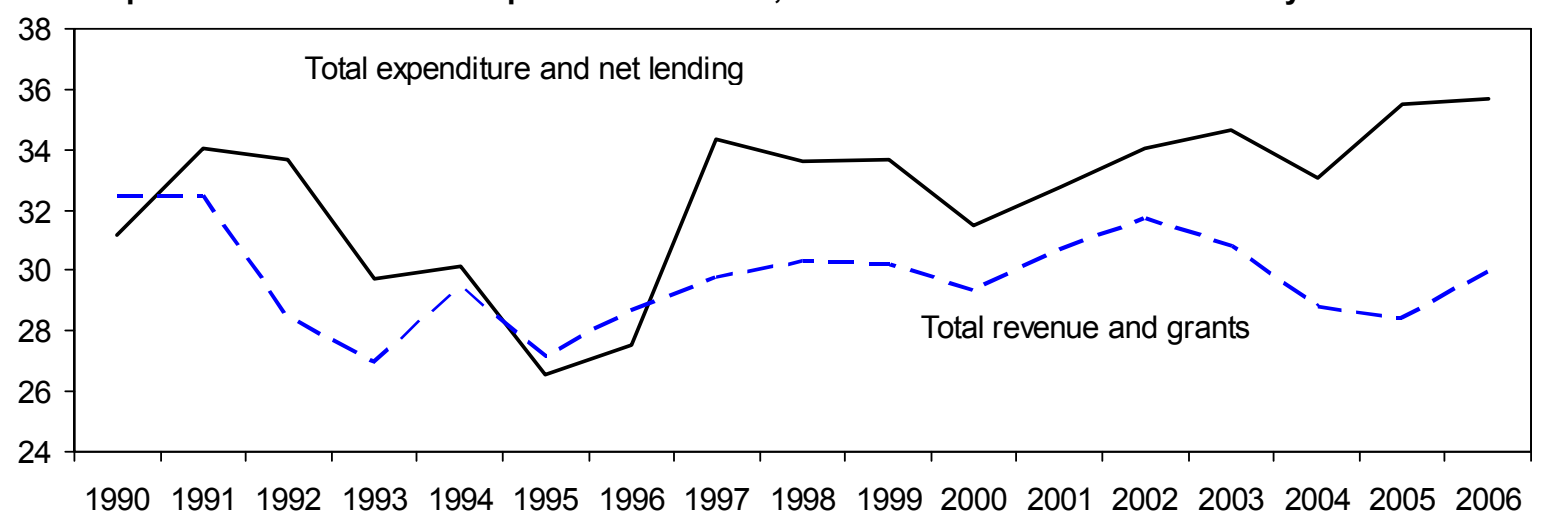

Despite some fiscal consolidation in 2006, high fiscal deficits in past years and the public assumption of a private external loan in $1999 . .$.

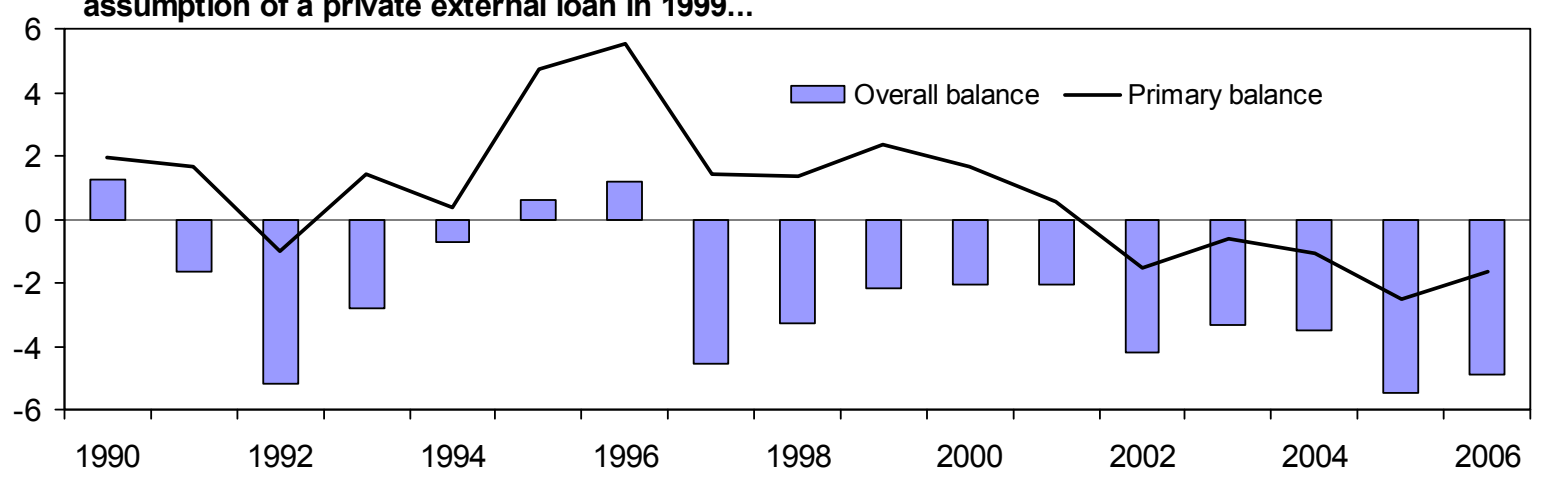

...have led to rising debt and debt servicing costs.

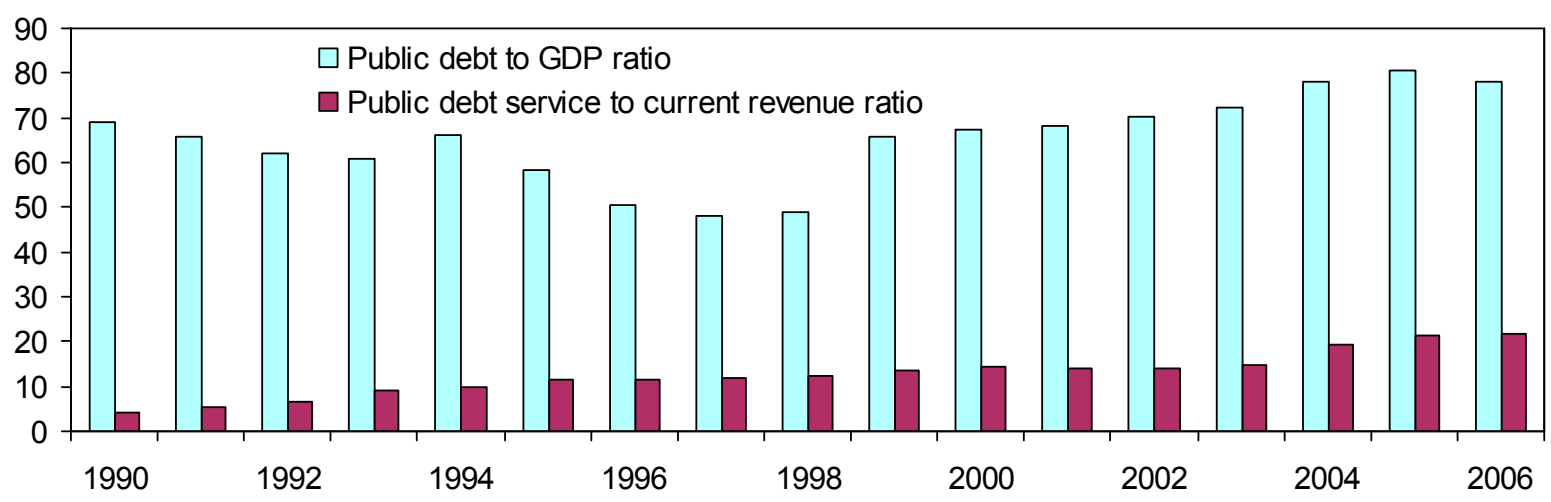

Sources: St. Vincent and the Grenadines authorities; and Fund staff estimates. 
Figure 3. St. Vincent and the Grenadines: External Competitiveness, 1991-2006
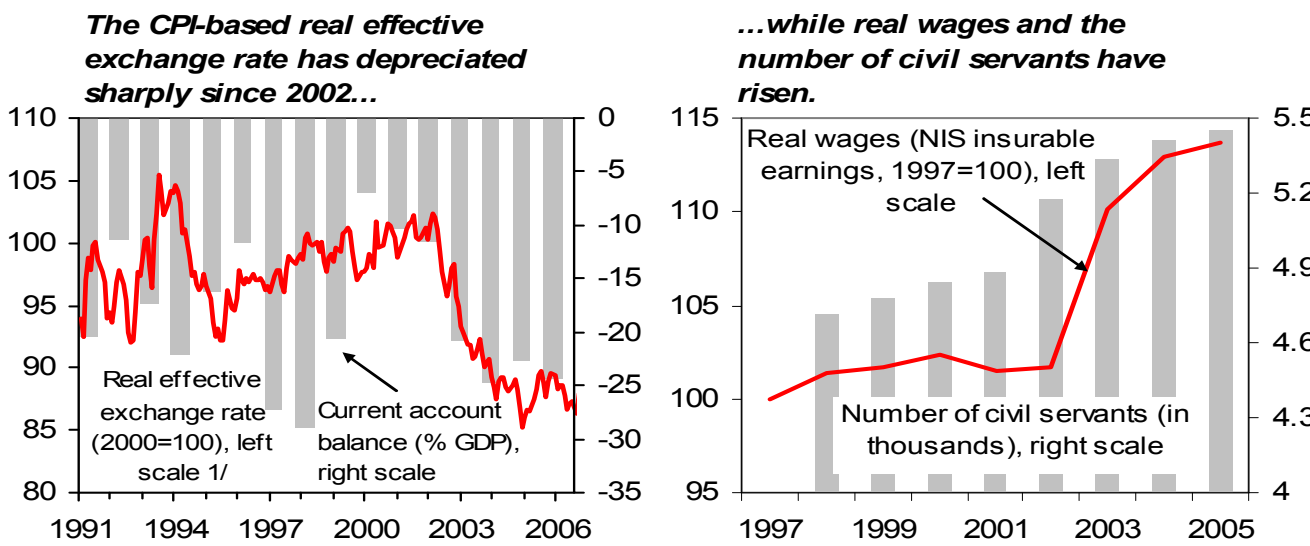

Exports have been on a declining trend...

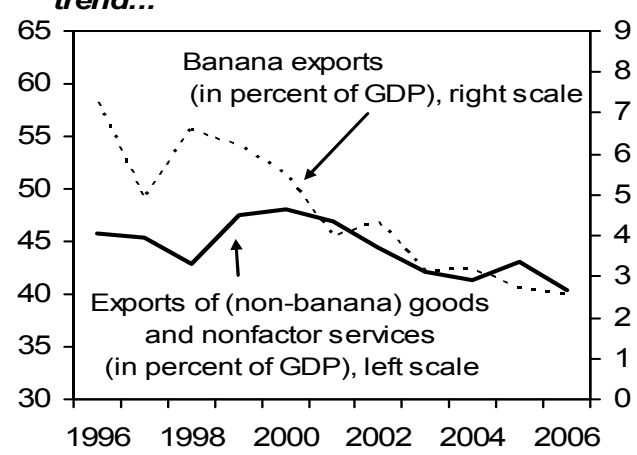

...while overseas development assistance flows collapsed in the 2000s.

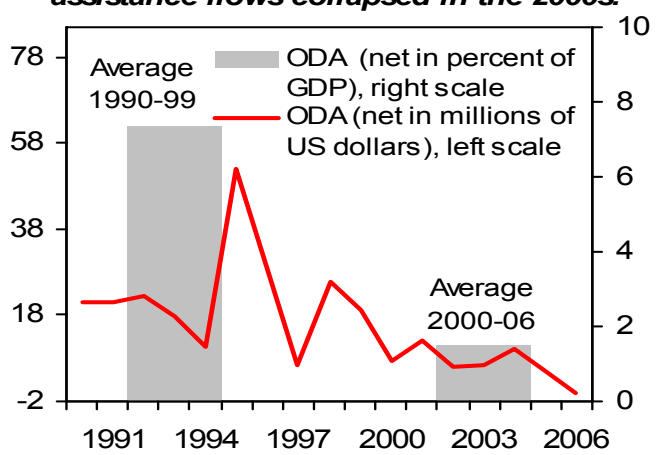

In the tourism sector, competitor- and customer-based measures of REER have improved in recent years.

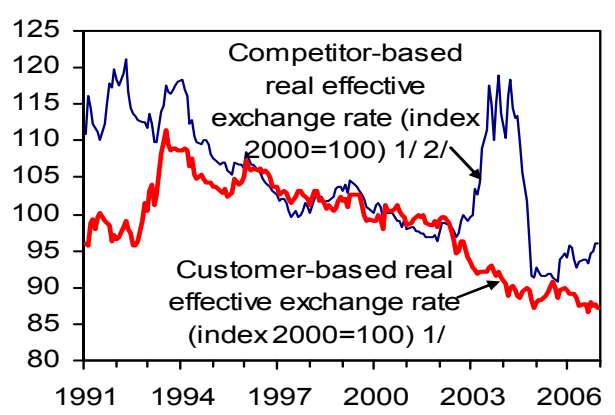

St. Vincent and the Grenadines' share of stay-over arrivals in the ECCU and the Caribbean was on an increasing trend, but has stalled in 2006.

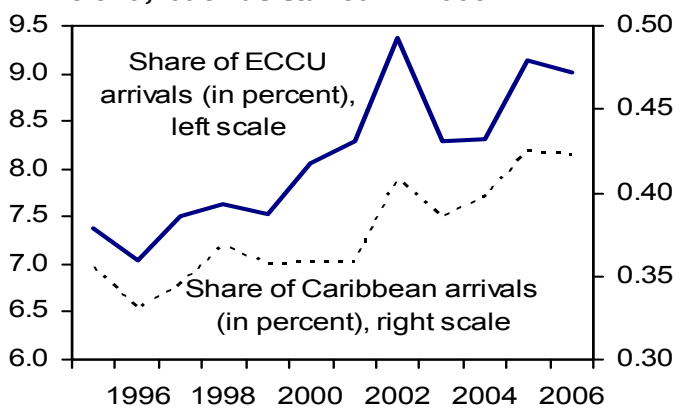

Sources: ECCB; Caribbean Tourism Organization; St. Vincent and the Grenadines authorities; and Fund staff calculations.

1/ An increase (decrease) indicates an appreciation (depreciation).

2/ The sharp movements in the competitor-based real exchange rate in 2002-04 were largely driven by movements in the Dominican Republic's peso. 
Figure 4: St. Vincent and the Grenadines: Monetary Developments, 2001-07

Private sector credit growth has accelerated...

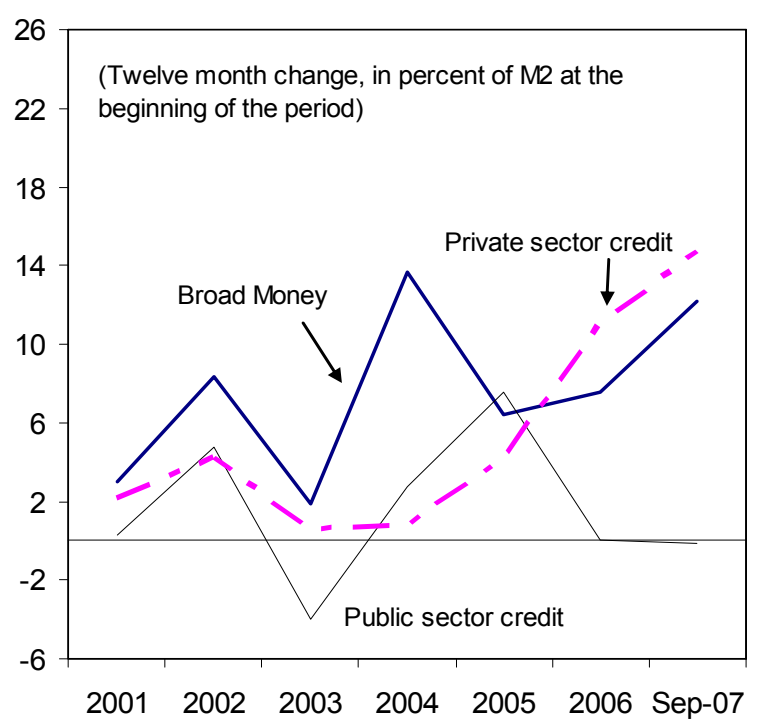

Dollarization has increased somewhat, following the removal of capital controls in 2004...

Dollarization (foreign currency deposits/ total deposits, in 25 percent)

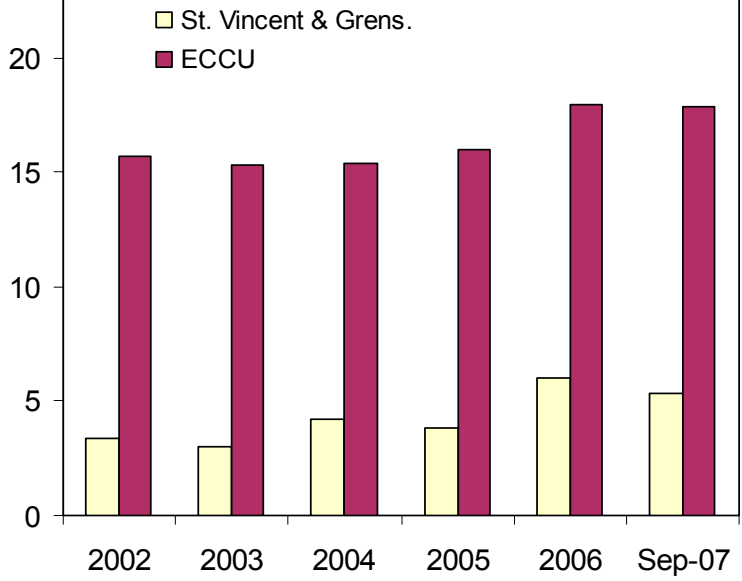

...reflecting growth mainly in tourism, personal loans, construction, and recently in manufacturing.

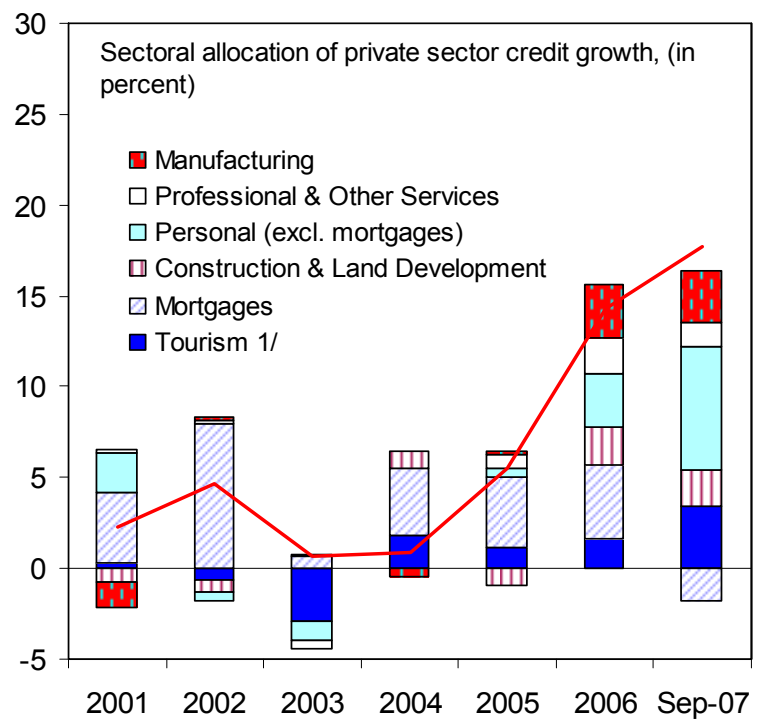

...with foreign-currency denominated deposits now increasingly held by households and public sector.

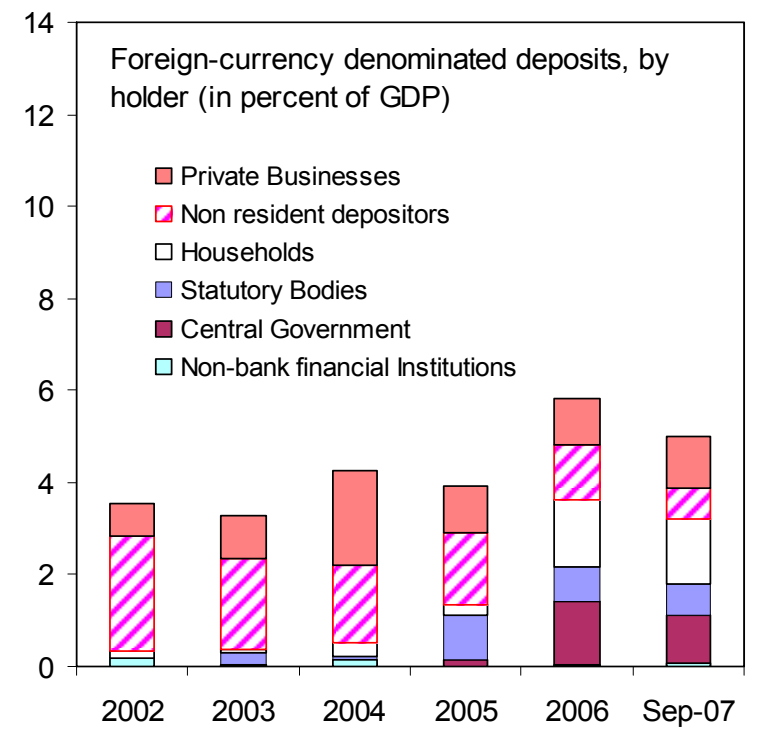

Sources: ECCB; and Fund staff calculations.

$1 /$ Includes tourism, entertainment, and half of transport, distributive trade and professional services. 
Figure 5. St. Vincent and the Grenadines: Banking System Vulnerabilities 1/

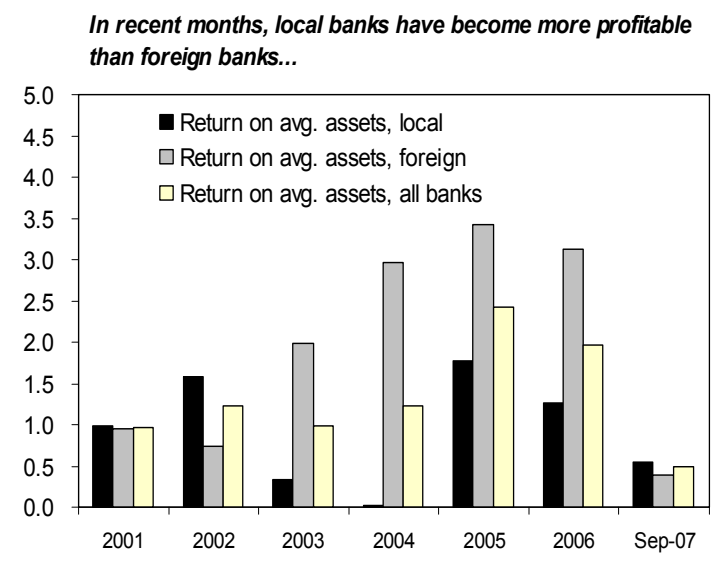

Government exposure remains high for local banks.

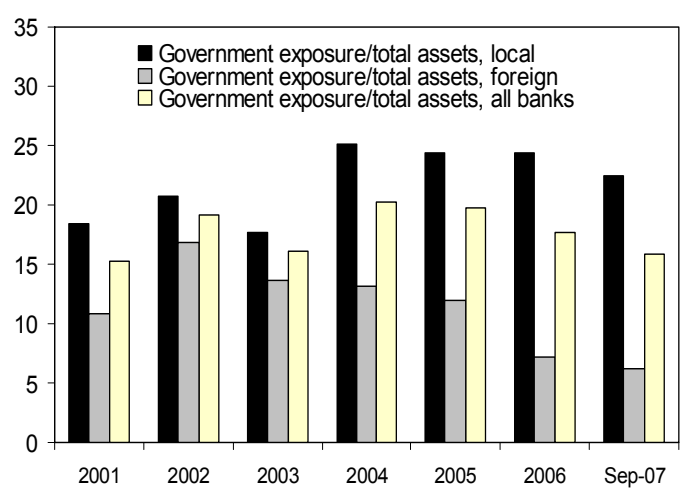

The declining trend in provisioning in foreign banks points to the need for vigilance in the banking sector...

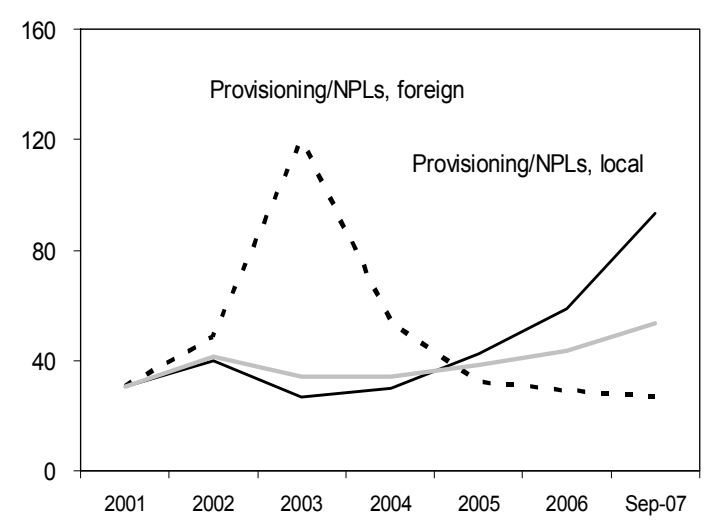

...despite having higher liquidity ratios and offering fewer loans as a share of deposits.

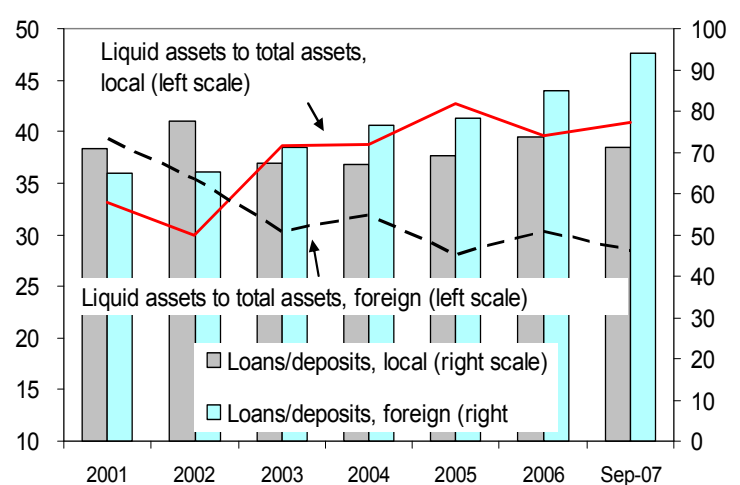

Nonperforming loans have declined significantly in recent years (particularly for local banks), partly as a result of the rapid credit expansion.

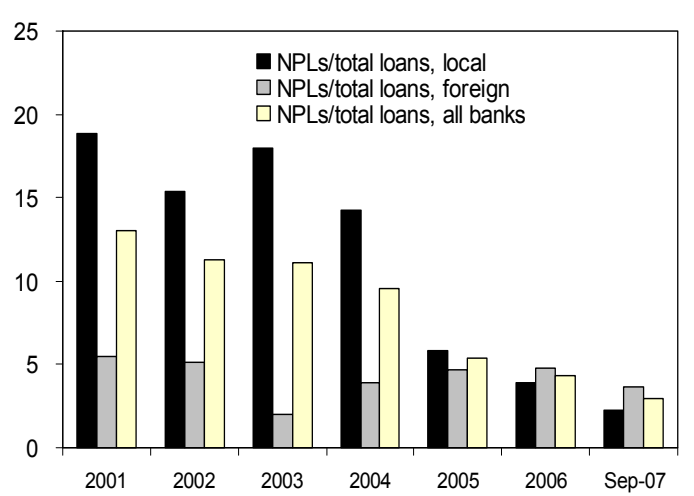

... even when capital adequacy ratios for local banks exhibit an increasing trend; and now exceed the ECCU average.

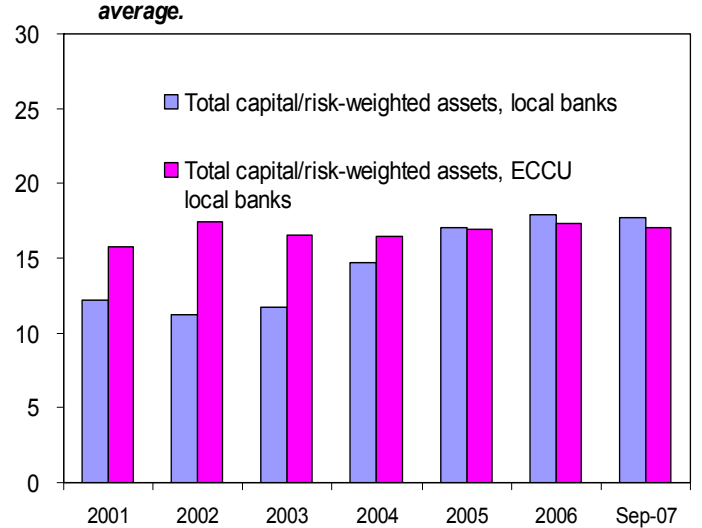

Sources: ECCB; and Fund staff calculations.

1/ Prudential indicators are reported by commercial banks, with infrequent onsite verification by the ECCB.

Note: September data is a quarterly return. 
Figure 6. St. Vincent and the Grenadines: Doing Business Indicators, 2007 1/
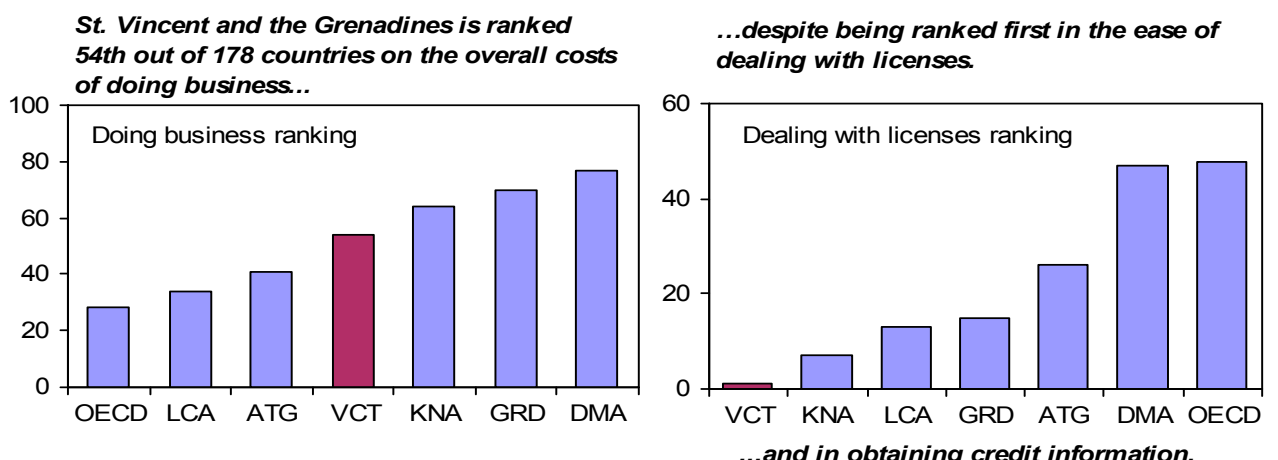

There are difficultes in registering property...
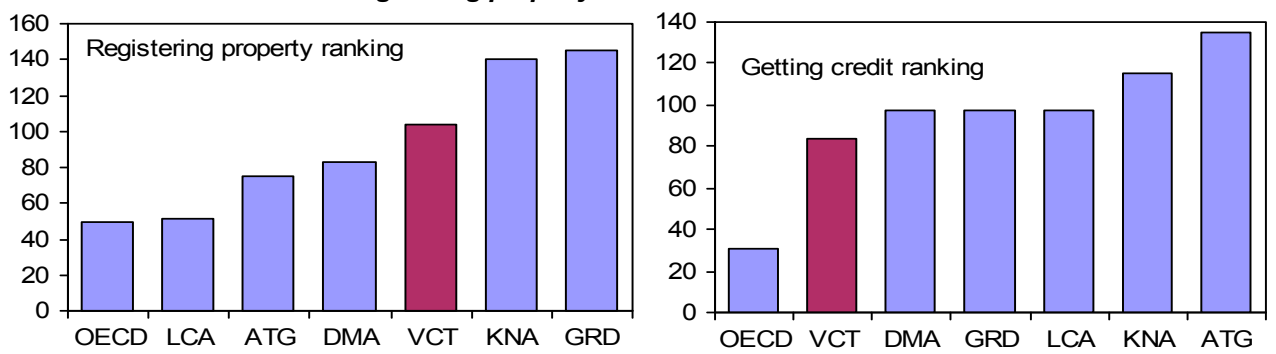

Import costs are also high. .

... and so are the costs of commercial contract enforcement...
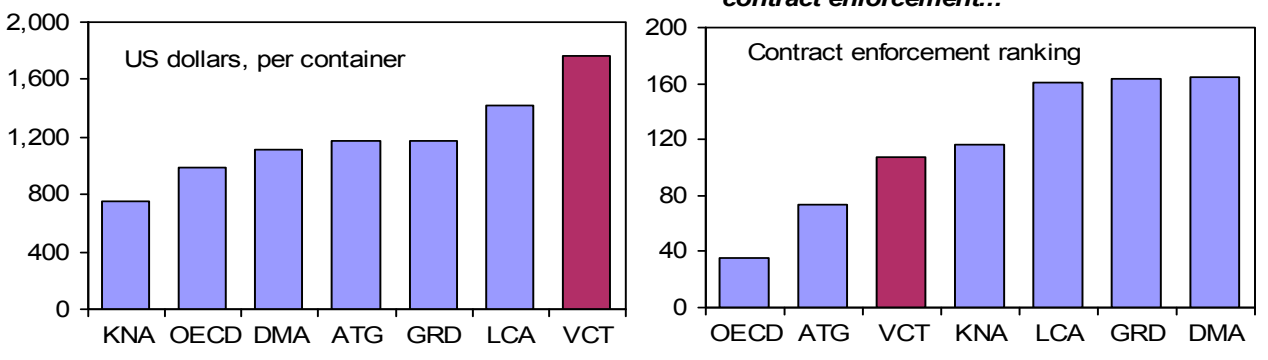

... and of closing a business.

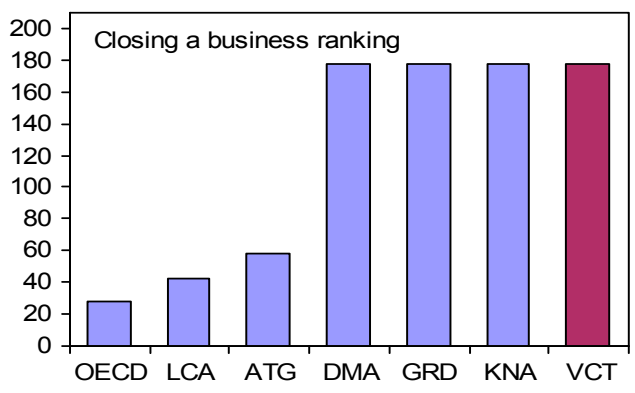

These impediments could be important in explaining the large informal sector.

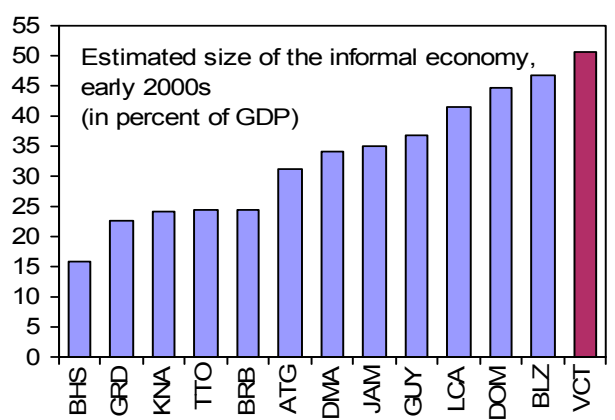

Sources: World Bank, 2008 Doing Business Indicators (2007); and Fund staff calculations.

Notation: Antigua and Barbuda (ATG), The Bahamas (BHS), Barbados (BRB), Belize (BLZ), Dominica (DMA), Dominican Republic (DOM), Grenada (GRD), Guyana (GUY), Jamaica (JAM), St. Kitts and Nevis (KNA), St. Lucia (LCA), St. Vincent and the Grenadines (VCT), and Trinidad and Tobago (TTO).

1/ Smaller numbers represent greater ease in doing business. The rankings are across 178 countries. 
Table 1. St. Vincent and the Grenadines: Selected Social and Economic Indicators, 2003-08

\begin{tabular}{|c|c|c|c|c|c|c|}
\hline \multicolumn{7}{|c|}{ Social and Demographic Indicators } \\
\hline Area (sq. km) & \multicolumn{5}{|c|}{ Adult illiteracy rate (percent, 2001) } & 11.0 \\
\hline Population & \multicolumn{6}{|c|}{ Health and nutrition } \\
\hline Total (thousands, 2006) & \multicolumn{5}{|c|}{ Calorie intake (per capita a day, 2004) } & 2,660 \\
\hline Rate of growth (percent per year, 2001) & \multicolumn{5}{|c|}{ Population per physician (thousand, 1997) } & 1.1 \\
\hline Density (per sq. km., 2006) & \multicolumn{5}{|c|}{ AIDS incidence rate (per $100,000,2004)$} & 99 \\
\hline Population characteristics (2004) & \multicolumn{6}{|c|}{ Gross domestic product (2006) } \\
\hline Life expectancy at birth (years) & \multirow{2}{*}{\multicolumn{5}{|c|}{$\begin{array}{l}\text { (millions of US dollars) } \\
\text { (millions of EC dollars) }\end{array}$}} & 493 \\
\hline Infant mortality (per thousand live births) & & & & & & 1,330 \\
\hline \multirow[t]{3}{*}{ Under 5 mortality rate (per thousand) } & \multicolumn{4}{|c|}{ (US\$ per capita) } & & 4,614 \\
\hline & \multirow[b]{2}{*}{2003} & \multirow[b]{2}{*}{2004} & \multirow[b]{2}{*}{2005} & \multirow{2}{*}{$\begin{array}{r}\text { Est. } \\
2006\end{array}$} & \multicolumn{2}{|c|}{ Proj. } \\
\hline & & & & & 2007 & 2008 \\
\hline \multicolumn{7}{|c|}{ Annual percentage change, unless otherwise specified } \\
\hline \multicolumn{7}{|l|}{ Output and prices } \\
\hline Real GDP (factor cost) & 2.8 & 6.8 & 2.6 & 6.9 & 6.7 & 5.0 \\
\hline Nominal GDP (market prices) & 4.7 & 8.3 & 5.7 & 12.6 & 11.9 & 10.6 \\
\hline Consumer prices, end of period & 2.7 & 1.7 & 3.9 & 4.8 & 8.2 & 3.6 \\
\hline Consumer prices, period average & 0.2 & 3.0 & 3.7 & 3.0 & 6.9 & 4.6 \\
\hline Real effective exchange rate $(-=$ depreciation $)$ & -7.3 & -3.6 & 0.1 & -0.6 & $\ldots$ & $\ldots$ \\
\hline External terms of trade (- = deterioration) & -0.9 & -8.6 & -3.0 & -5.7 & -2.6 & 1.1 \\
\hline \multicolumn{7}{|l|}{ Banking system } \\
\hline Net foreign assets $1 /$ & 5.7 & 15.7 & -4.6 & 4.5 & -5.0 & 6.1 \\
\hline Net domestic assets $1 /$ & -3.9 & -2.0 & 11.0 & 3.0 & 18.4 & 4.5 \\
\hline Of which & & & & & & \\
\hline Credit to private sector $1 /$ & 0.6 & 0.8 & 4.3 & 11.1 & 13.1 & 6.8 \\
\hline (In percent of GDP, $u$ & herwise specif & & & & & \\
\hline Central government finances & & & & & & \\
\hline Total revenue and grants & 31.3 & 29.6 & 30.0 & 30.8 & 31.0 & 31.6 \\
\hline Total expenditure and net lending & 34.7 & 33.1 & 35.5 & 35.7 & 35.1 & 35.0 \\
\hline Current expenditure & 26.7 & 26.0 & 27.3 & 26.8 & 26.3 & 27.1 \\
\hline Of which & & & & & & \\
\hline Wages and salaries & 13.5 & 13.1 & 13.5 & 12.9 & 12.8 & 12.5 \\
\hline Interest & 2.7 & 2.5 & 3.0 & 3.2 & 3.5 & 4.1 \\
\hline Capital expenditure & 7.9 & 7.1 & 8.2 & 8.9 & 8.9 & 7.9 \\
\hline Overall balance (cash basis) $2 /$ & -3.3 & -3.5 & -5.5 & -4.9 & -4.2 & -3.4 \\
\hline Of which & & & & & & \\
\hline Primary balance (after grants) & -0.6 & -1.1 & -2.5 & -1.7 & -0.7 & 0.7 \\
\hline Central government debt & 67.7 & 69.3 & 71.4 & 68.4 & 55.0 & 53.0 \\
\hline Public sector overall balance 3 / & -3.0 & -6.8 & -7.7 & -6.3 & -7.2 & -7.0 \\
\hline Public sector primary balance 3 / & -0.2 & -4.0 & -4.0 & -2.5 & -2.7 & -2.0 \\
\hline Public sector investment $3 /$ & 10.0 & 12.9 & 12.6 & 14.3 & 17.2 & 18.2 \\
\hline External sector & & & & & & \\
\hline External current account & -20.8 & -24.8 & -22.7 & -24.4 & -26.9 & -26.8 \\
\hline Of which & & & & & & \\
\hline Exports of goods and services & 45.2 & 44.6 & 45.8 & 43.0 & 40.5 & 39.7 \\
\hline Imports of goods and services & 63.1 & 65.7 & 66.5 & 66.6 & 66.9 & 65.4 \\
\hline Stayover arrivals (percentage change) & 1.2 & 10.4 & 9.5 & 2.6 & 0.0 & 5.0 \\
\hline Public sector external debt (end of period) & 50.9 & 53.3 & 53.8 & 48.0 & 32.8 & 33.7 \\
\hline External public debt service & & & & & & \\
\hline In percent of exports of goods and services & 7.1 & 9.8 & 10.7 & 11.8 & 12.1 & 13.3 \\
\hline Memorandum items: & & & & & & \\
\hline Gross public sector debt $3 / 4 /$ & 72.3 & 77.0 & 80.7 & 78.0 & 67.6 & 68.0 \\
\hline Nominal GDP at market prices (in millions of E.C. dollars) & 1,032 & 1,118 & 1,182 & 1,330 & 1,489 & 1,646 \\
\hline Nominal GDP at market prices (in millions of U.S. dollars) & 382 & 414 & 438 & 493 & 551 & 610 \\
\hline Share of ECCU stayover visitors & 9.0 & 8.3 & 8.3 & 9.1 & 9.0 & $\ldots$ \\
\hline
\end{tabular}

Sources: ECCB; Ministry of Finance and Planning; Banana Growers' Association; and Fund staff estimates and projections.

$1 /$ Annual changes relative to the stock of broad money at the beginning of the period.

$2 /$ Includes the difference between the overall balance as measured from above the line and from below the line (i.e., financing), which may include float and unidentified discrepancies.

3/ The consolidated public sector includes the central government, the NIS, Kingstown Board, and ten nonfinancial public enterprises.

4/ Net of intra-public sector debt (mainly central government debt to the National Insurance Scheme (NIS)). 
Table 2a. St. Vincent and the Grenadines: Summary of Central Government Operations, 2003-12

(In millions of Eastern Caribbean dollars)

\begin{tabular}{|c|c|c|c|c|c|c|c|c|c|c|}
\hline & \multirow[b]{2}{*}{2003} & \multirow[b]{2}{*}{2004} & \multirow[b]{2}{*}{2005} & \multirow[b]{2}{*}{2006} & \multicolumn{6}{|c|}{ Baseline Proj. } \\
\hline & & & & & 2007 & 2008 & 2009 & 2010 & 2011 & 2012 \\
\hline Total revenue and grants & 324 & 331 & 354 & 409 & 461 & 520 & 563 & 604 & 659 & 715 \\
\hline Current revenue & 318 & 322 & 336 & 399 & 436 & 496 & 536 & 575 & 628 & 681 \\
\hline Tax & 260 & 274 & 308 & 363 & 398 & 454 & 490 & 525 & 572 & 620 \\
\hline Nontrade tax & 127 & 136 & 166 & 200 & 236 & 276 & 297 & 311 & 340 & 368 \\
\hline VAT (formerly consumption tax) & & & & 7 & 40 & 62 & 68 & 75 & 81 & 88 \\
\hline Personal income tax & 35 & 37 & 41 & 49 & 52 & 54 & 56 & 62 & 68 & 73 \\
\hline Corporate income tax & 38 & 37 & 44 & 43 & 40 & 41 & 42 & 46 & 50 & 54 \\
\hline Stamp tax & 12 & 21 & 21 & 38 & 31 & 48 & 53 & 42 & 46 & 50 \\
\hline International trade & 133 & 138 & 142 & 163 & 161 & 177 & 193 & 214 & 233 & 252 \\
\hline VAT (formerly consumption tax) & & & & 94 & 80 & 89 & 100 & 110 & 120 & 130 \\
\hline Nontax & 58 & 48 & 28 & 36 & 38 & 42 & 46 & 51 & 56 & 60 \\
\hline Capital revenue (land sales only) & 1 & 1 & 1 & 1 & 1 & 1 & 1 & 1 & 1 & 1 \\
\hline Grants & 5 & 8 & 17 & 9 & 25 & 23 & 25 & 28 & 31 & 33 \\
\hline $\begin{array}{l}\text { Total expenditure and net lending } \\
\text { Current }\end{array}$ & $\begin{array}{l}358 \\
276\end{array}$ & $\begin{array}{l}370 \\
290\end{array}$ & $\begin{array}{l}419 \\
322\end{array}$ & $\begin{array}{l}474 \\
356\end{array}$ & $\begin{array}{l}523 \\
391\end{array}$ & $\begin{array}{l}576 \\
446\end{array}$ & $\begin{array}{l}634 \\
490\end{array}$ & $\begin{array}{l}698 \\
541\end{array}$ & $\begin{array}{l}766 \\
593\end{array}$ & $\begin{array}{l}831 \\
645\end{array}$ \\
\hline Wages and salaries $1 /$ & 139 & 147 & 159 & 171 & 190 & 205 & 226 & 248 & 272 & 294 \\
\hline $\begin{array}{l}\text { Interest } \\
\text { Of which }\end{array}$ & 28 & 28 & 35 & 43 & 52 & 68 & 74 & 83 & 93 & 103 \\
\hline Foreign interest & 11 & 14 & 20 & 23 & 27 & 35 & 35 & 38 & 40 & \\
\hline Goods and services & 61 & 67 & 68 & 77 & 73 & 99 & 109 & 120 & 131 & 142 \\
\hline Transfers $2 /$ & 48 & 49 & 61 & 65 & 75 & 74 & 82 & 90 & 98 & 106 \\
\hline Capital expenditure & 82 & 80 & 97 & 118 & 132 & 130 & 143 & 157 & 172 & 187 \\
\hline Net lending & 0 & 0 & 0 & 0 & 0 & 0 & 0 & 0 & 0 & \\
\hline Current balance (before grants) & 42 & 32 & 14 & 43 & 45 & 50 & 46 & 35 & 34 & 36 \\
\hline Overall balance & -34 & -39 & -65 & -65 & -62 & -57 & -71 & -94 & -106 & -117 \\
\hline Of which & & & & & & & & & & \\
\hline Primary balance & -7 & -12 & -30 & -22 & -10 & 11 & 3 & -11 & -13 & -14 \\
\hline Identified financing & 34 & 39 & 65 & 65 & 62 & 57 & 71 & 94 & 106 & 117 \\
\hline Net external financing & 46 & 71 & 37 & -9 & -39 & 21 & -4 & 38 & 55 & 26 \\
\hline Disbursements & 65 & 105 & 74 & 35 & 7 & 73 & 57 & 102 & 121 & 93 \\
\hline Amortization & 19 & 35 & 37 & 44 & 46 & 52 & 61 & 65 & 66 & 67 \\
\hline Change in government foreign assets & 2 & 2 & 0 & 0 & 0 & 0 & 0 & 0 & 0 & 0 \\
\hline $\begin{array}{l}\text { Net domestic financing } \\
\text { Of which }\end{array}$ & -15 & -33 & 28 & 74 & 101 & 35 & 75 & 56 & 52 & 91 \\
\hline $\begin{array}{l}\text { Of which } \\
\text { Banking system }\end{array}$ & -51 & 16 & 47 & -3 & 53 & 18 & 39 & 29 & 27 & 47 \\
\hline Exceptional financing & 1 & 0 & 0 & 0 & 0 & 0 & 0 & 0 & 0 & 0 \\
\hline & & & & & & & & & & \\
\hline Wage and salaries as a share of recurrent expenditures & 50.4 & 50.6 & 49.3 & 48.1 & 48.6 & 46.0 & 46.1 & 46.0 & 45.8 & $\begin{array}{l}45.6 \\
22.0\end{array}$ \\
\hline Goods and services as a share of recurrent expenditures & 22.3 & 23.0 & 21.1 & 21.5 & 18.7 & 22.1 & 22.2 & 22.1 & 22.0 & 22.0 \\
\hline Capital expenditure as a share of total expenditures & 22.9 & 21.6 & 23.1 & 24.9 & 25.3 & 22.6 & 22.6 & 22.6 & 22.5 & 22.4 \\
\hline
\end{tabular}

Sources: Ministry of Finance and Planning; and Fund staff estimates and projections.

$1 /$ Salaries and wages including social security contributions, commissions, rewards, allowances, and incentives.

2/ Mainly contributions to households and international organizations. 
Table 2b. St. Vincent and the Grenadines: Summary of Central Government Operations, 2003-12

(In millions of Eastern Caribbean dollars)

\begin{tabular}{|c|c|c|c|c|c|c|c|c|c|c|}
\hline & \multirow[b]{2}{*}{2003} & \multirow[b]{2}{*}{2004} & \multirow[b]{2}{*}{2005} & \multirow[b]{2}{*}{2006} & \multicolumn{6}{|c|}{ Active Proj. } \\
\hline & & & & & 2007 & 2008 & 2009 & 2010 & 2011 & 2012 \\
\hline Total revenue and grants & 324 & 331 & 354 & 409 & 461 & 536 & 601 & 647 & 708 & 772 \\
\hline Current revenue & 318 & 322 & 336 & 399 & 436 & 506 & 569 & 612 & 670 & 730 \\
\hline Nontrade tax & 127 & 136 & 166 & 200 & 236 & 286 & 325 & 344 & 377 & 410 \\
\hline VAT (formerly consumption tax) & & & & 7 & 40 & 62 & 69 & 76 & 83 & 91 \\
\hline Personal income tax & 35 & 37 & 41 & 49 & 52 & 58 & 64 & 71 & 78 & 85 \\
\hline Corporate income tax & 38 & 37 & 44 & 43 & 40 & 45 & 49 & 55 & 60 & 65 \\
\hline Stamp tax & 12 & 21 & 21 & 38 & 31 & 48 & 53 & 43 & 47 & 51 \\
\hline International trade & 133 & 138 & 142 & 163 & 161 & 178 & 197 & 216 & 236 & 258 \\
\hline Nontax & 58 & 48 & 28 & 36 & 38 & 42 & 47 & 52 & 57 & 62 \\
\hline Capital revenue (land sales only) & 1 & 1 & 1 & 1 & 1 & 1 & 1 & 1 & 1 & 1 \\
\hline Grants & 5 & 8 & 17 & 9 & 25 & 28 & 31 & 35 & 38 & 41 \\
\hline Total expenditure and net lending & 358 & 370 & 419 & 474 & 523 & 571 & 609 & 659 & 705 & 749 \\
\hline Current & 276 & 290 & 322 & 356 & 391 & 446 & 472 & 506 & 541 & 574 \\
\hline Wages and salaries 1/ & 139 & 147 & 159 & 171 & 190 & 205 & 213 & 226 & 240 & 254 \\
\hline $\begin{array}{l}\text { Interest } \\
\text { Of which }\end{array}$ & 28 & 28 & 35 & 43 & 52 & 67 & 69 & 71 & 72 & 71 \\
\hline Foreign interest & 11 & 14 & 20 & 23 & 27 & 35 & 35 & 36 & 36 & 36 \\
\hline Goods and services & 61 & 67 & 68 & 77 & 73 & 99 & 110 & 122 & 134 & 145 \\
\hline Transfers $2 /$ & 48 & 49 & 61 & 65 & 75 & 75 & 79 & 87 & 96 & 104 \\
\hline Current balance (before grants) & 42 & 32 & 14 & 43 & 45 & 60 & 97 & 105 & 129 & 156 \\
\hline $\begin{array}{l}\text { Overall balance } \\
\text { Of which }\end{array}$ & -34 & -39 & -65 & -65 & -62 & -35 & -8 & -11 & 3 & 23 \\
\hline Primary balance & -7 & -12 & -30 & -22 & -10 & 32 & 61 & 60 & 75 & 94 \\
\hline Identified financing & 34 & 39 & 65 & 65 & 62 & 35 & 8 & 11 & -3 & -23 \\
\hline Net external financing & 46 & 71 & 37 & -9 & -39 & 21 & -6 & -4 & 0 & 2 \\
\hline Disbursements & 65 & 105 & 74 & 35 & 7 & 73 & 55 & 61 & 66 & 70 \\
\hline Amortization & 19 & 35 & 37 & 44 & 46 & 52 & 61 & 65 & 66 & 67 \\
\hline Change in government foreign assets & 2 & 2 & 0 & 0 & 0 & 0 & 0 & 0 & 0 & 0 \\
\hline $\begin{array}{l}\text { Net domestic financing } \\
\text { Of which }\end{array}$ & -15 & -33 & 28 & 74 & 101 & 14 & 14 & 15 & -3 & -26 \\
\hline Banking system & -51 & 16 & 47 & -3 & 53 & 7 & 8 & 8 & -2 & -13 \\
\hline Exceptional financing & 1 & 0 & 0 & 0 & 0 & 0 & 0 & 0 & 0 & 0 \\
\hline Memorandum items: & & & & & & & & & & \\
\hline Wage and salaries as a share of recurrent expenditures & 50.4 & 50.6 & 49.3 & 48.1 & 48.6 & 46.0 & 45.2 & 44.6 & 44.3 & 44.2 \\
\hline Goods and services as a share of recurrent expenditures & 22.3 & 23.0 & 21.1 & 21.5 & 18.7 & 22.3 & 23.3 & 24.1 & 24.7 & 25.3 \\
\hline Capital expenditure as a share of total expenditures & 22.9 & 21.6 & 23.1 & 24.9 & 25.3 & 21.8 & 22.6 & 23.1 & 23.4 & 23.3 \\
\hline
\end{tabular}

Sources: Ministry of Finance and Planning; and Fund staff estimates and projections.

1/ Salaries and wages including social security contributions, commissions, rewards, allowances, and incentives.

2/ Mainly contributions to households and international organizations. 
Table 3a. St. Vincent and the Grenadines: Summary of Central Government Operations, 2003-12 (In percent of GDP, unless otherwise stated)

\begin{tabular}{|c|c|c|c|c|c|c|c|c|c|c|}
\hline & \multirow[b]{2}{*}{2003} & \multirow[b]{2}{*}{2004} & \multirow[b]{2}{*}{2005} & \multirow[b]{2}{*}{2006} & \multicolumn{6}{|c|}{ Baseline Proj. } \\
\hline & & & & & 2007 & 2008 & 2009 & 2010 & 2011 & 2012 \\
\hline Total revenue and grants & 31.3 & 29.6 & 30.0 & 30.8 & 31.0 & 31.6 & 31.0 & 30.3 & 30.3 & 30.3 \\
\hline Current revenue & 30.8 & 28.8 & 28.5 & 30.0 & 29.3 & 30.1 & 29.6 & 28.9 & 28.8 & 28.8 \\
\hline Tax & 25.2 & 24.5 & 26.1 & 27.3 & 26.7 & 27.5 & 27.0 & 26.3 & 26.3 & 26.3 \\
\hline Nontrade tax & 12.3 & 12.2 & 14.0 & 15.0 & 15.9 & 16.8 & 16.4 & 15.6 & 15.6 & 15.6 \\
\hline VAT (formerly consumption tax) & $\ldots$ & $\ldots$ & $\ldots$ & 0.5 & 2.7 & 3.7 & 3.7 & 3.7 & 3.7 & 3.7 \\
\hline Personal income tax & 3.4 & 3.3 & 3.5 & 3.7 & 3.5 & 3.3 & 3.1 & 3.1 & 3.1 & 3.1 \\
\hline Corporate income tax & 3.7 & 3.4 & 3.8 & 3.3 & 2.7 & 2.5 & 2.3 & 2.3 & 2.3 & 2.3 \\
\hline Stamp tax & 1.1 & 1.9 & 1.8 & 2.9 & 2.1 & 2.9 & 2.9 & 2.1 & 2.1 & 2.1 \\
\hline International trade & 12.9 & 12.4 & 12.0 & 12.3 & 10.8 & 10.8 & 10.6 & 10.7 & 10.7 & 10.7 \\
\hline VAT (formerly consumption tax) & & & & 7.1 & 5.4 & 5.4 & 5.5 & 5.5 & 5.5 & 5.5 \\
\hline Nontax & 5.7 & 4.3 & 2.4 & 2.7 & 2.6 & 2.6 & 2.6 & 2.6 & 2.6 & 2.6 \\
\hline Capital revenue (land sales only) & 0.1 & 0.1 & 0.1 & 0.1 & 0.1 & 0.1 & 0.1 & 0.1 & 0.0 & 0.0 \\
\hline Grants & 0.4 & 0.7 & 1.5 & 0.7 & 1.6 & 1.4 & 1.4 & 1.4 & 1.4 & 1.4 \\
\hline Total expenditure and net lending & 34.7 & 33.1 & 35.5 & 35.7 & 35.1 & 35.0 & 34.9 & 35.0 & 35.1 & 35.2 \\
\hline Current & 26.7 & 26.0 & 27.3 & 26.8 & 26.3 & 27.1 & 27.0 & 27.1 & 27.2 & 27.3 \\
\hline Wages and salaries $1 /$ & 13.5 & 13.1 & 13.5 & 12.9 & 12.8 & 12.5 & 12.5 & 12.5 & 12.5 & 12.5 \\
\hline Interest & 2.7 & 2.5 & 3.0 & 3.2 & 3.5 & 4.1 & 4.1 & 4.2 & 4.3 & 4.3 \\
\hline \multicolumn{11}{|l|}{ Of which } \\
\hline Foreign interest & 1.1 & 1.3 & 1.7 & 1.7 & 1.8 & 2.1 & 1.9 & 1.9 & 1.8 & 1.7 \\
\hline Goods and services & 6.0 & 6.0 & 5.7 & 5.8 & 4.9 & 6.0 & 6.0 & 6.0 & 6.0 & 6.0 \\
\hline Transfers 2/ & 4.6 & 4.4 & 5.1 & 4.9 & 5.1 & 4.5 & 4.5 & 4.5 & 4.5 & 4.5 \\
\hline Capital expenditure & 7.9 & 7.1 & 8.2 & 8.9 & 8.9 & 7.9 & 7.9 & 7.9 & 7.9 & 7.9 \\
\hline Net lending & 0.0 & 0.0 & 0.0 & 0.0 & 0.0 & 0.0 & 0.0 & 0.0 & 0.0 & 0.0 \\
\hline Current balance (before grants) & 4.1 & 2.9 & 1.2 & 3.2 & 3.0 & 3.0 & 2.5 & 1.8 & 1.6 & 1.5 \\
\hline Overall balance & -3.3 & -3.5 & -5.5 & -4.9 & -4.2 & -3.4 & -3.9 & -4.7 & -4.9 & -4.9 \\
\hline \multicolumn{11}{|l|}{ Of which } \\
\hline Primary balance & -0.6 & -1.1 & -2.5 & -1.7 & -0.7 & 0.7 & 0.2 & -0.5 & -0.6 & -0.6 \\
\hline Identified financing & 3.3 & 3.5 & 5.5 & 4.9 & 4.2 & 3.4 & 3.9 & 4.7 & 4.9 & 4.9 \\
\hline Net external financing & 4.5 & 6.3 & 3.1 & -0.7 & -2.7 & 1.3 & -0.2 & 1.9 & 2.5 & 1.1 \\
\hline Disbursements & 6.3 & 9.4 & 6.2 & 2.7 & 0.4 & 4.4 & 3.2 & 5.1 & 5.5 & 4.0 \\
\hline Amortization & 1.8 & 3.1 & 3.1 & 3.3 & 3.1 & 3.1 & 3.4 & 3.3 & 3.0 & 2.9 \\
\hline Change in government foreign assets & 0.2 & 0.2 & 0.0 & 0.0 & 0.0 & 0.0 & 0.0 & 0.0 & 0.0 & 0.0 \\
\hline Net domestic financing & -1.5 & -3.0 & 2.4 & 5.6 & 6.8 & 2.1 & 4.1 & 2.8 & 2.4 & 3.8 \\
\hline Of which & & & & & & & & & & \\
\hline Banking system & -4.9 & 1.5 & 4.0 & -0.2 & 3.5 & 1.1 & 2.1 & 1.5 & 1.2 & 2.0 \\
\hline Exceptional financing & 0.1 & 0.0 & 0.0 & 0.0 & 0.0 & 0.0 & 0.0 & 0.0 & 0.0 & 0.0 \\
\hline \multicolumn{11}{|l|}{ Memorandum items: } \\
\hline Gross central government debt (in percent of GDP) & 67.7 & 69.3 & 71.4 & 68.4 & 55.0 & 53.0 & 51.9 & 51.8 & 52.2 & 53.0 \\
\hline Public sector debt (in percent of GDP) $3 /$ & 72.3 & 77.0 & 80.7 & 78.0 & 67.6 & 68.0 & 67.3 & 69.4 & 70.8 & 71.7 \\
\hline Debt service as a proportion of current revenues 4 / & 14.7 & 19.3 & 21.3 & 22.0 & 22.6 & 24.1 & 25.2 & 25.7 & 25.3 & 25.0 \\
\hline GDP at market prices (EC $\$$ millions) & 1,032 & 1,118 & 1,182 & 1,330 & 1,489 & 1,646 & 1,814 & 1,994 & 2,179 & 2,362 \\
\hline
\end{tabular}

Sources: Ministry of Finance and Planning; and Fund staff estimates and projections.

$1 /$ Salaries and wages including social security contributions, commissions, rewards, allowances, and incentives. 2/ Mainly contributions to households and international organizations.

$3 /$ Net of intra-public sector debt (mainly central government debt to the NIS).

4/ Debt service excludes domestic debt amortization. 
Table 3b. St. Vincent and the Grenadines: Summary of Central Government Operations, 2003-12

(In percent of GDP, unless otherwise stated)

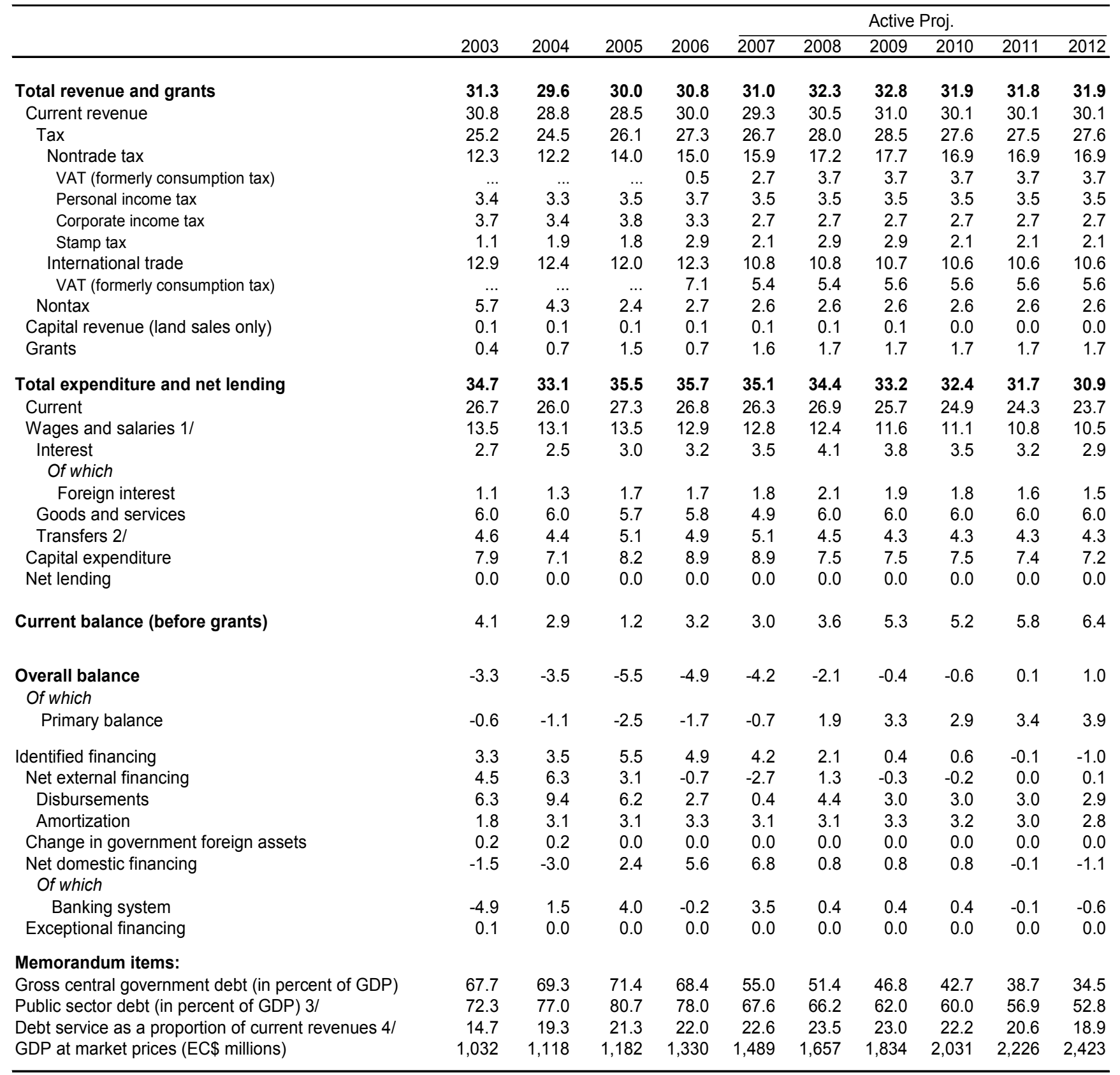

Sources: Ministry of Finance and Planning; and Fund staff estimates and projections.

$1 /$ Salaries and wages including social security contributions, commissions, rewards, allowances, and incentives.

2/ Mainly contributions to households and international organizations.

$3 /$ Net of intra-public sector debt (mainly central government debt to the NIS).

4/ Debt service excludes domestic debt amortization. 
Table 4. St. Vincent and the Grenadines: Balance of Payments Summary, 2003-12

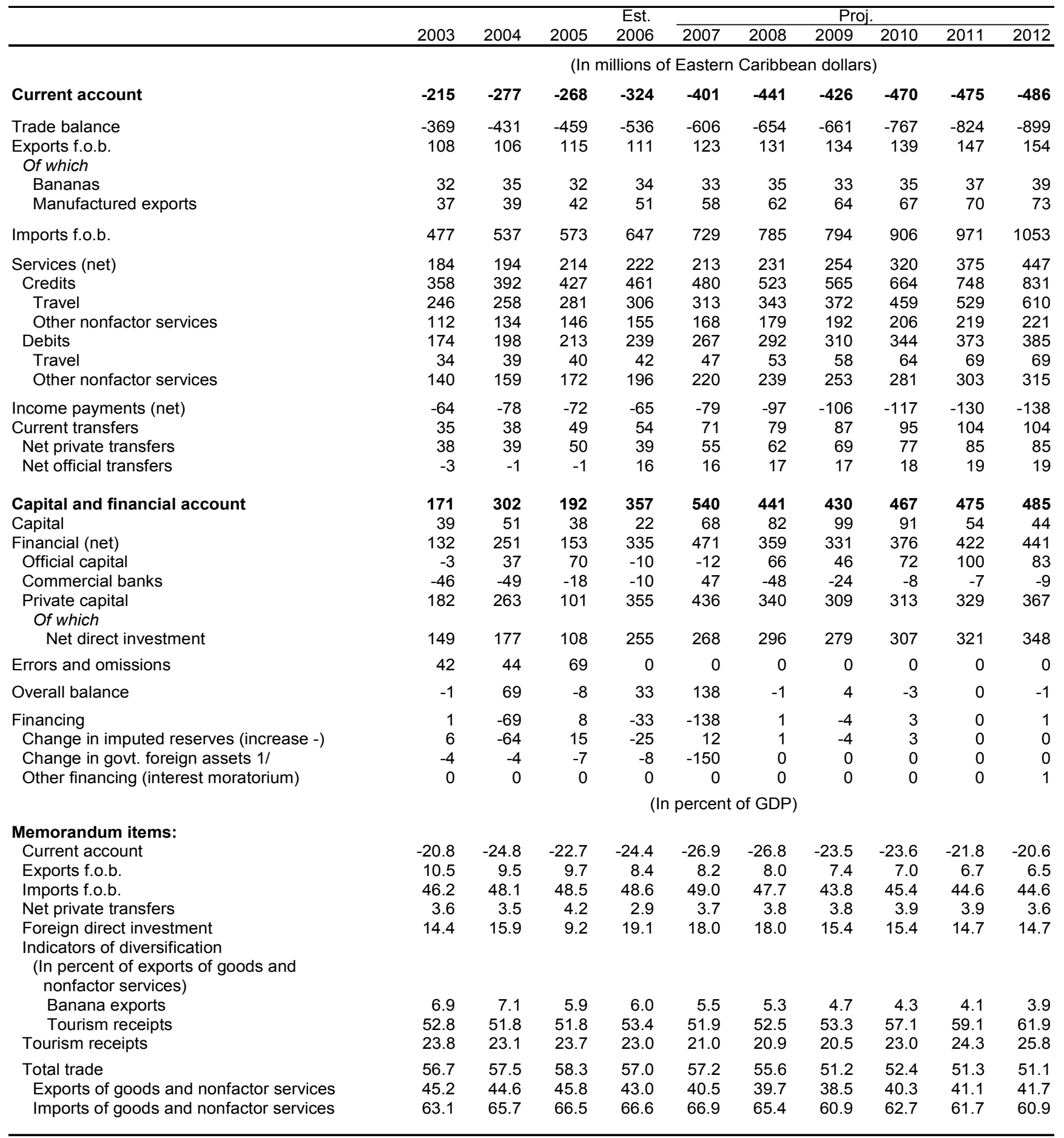

Sources: Ministry of Finance and Planning; ECCB; and Fund staff estimates and projections.

$1 /$ The large change in government foreign assets in 2007 is the result of the Ottley-Hall debt write-off. 
Table 5. St. Vincent and the Grenadines: Monetary Survey, 2003-08

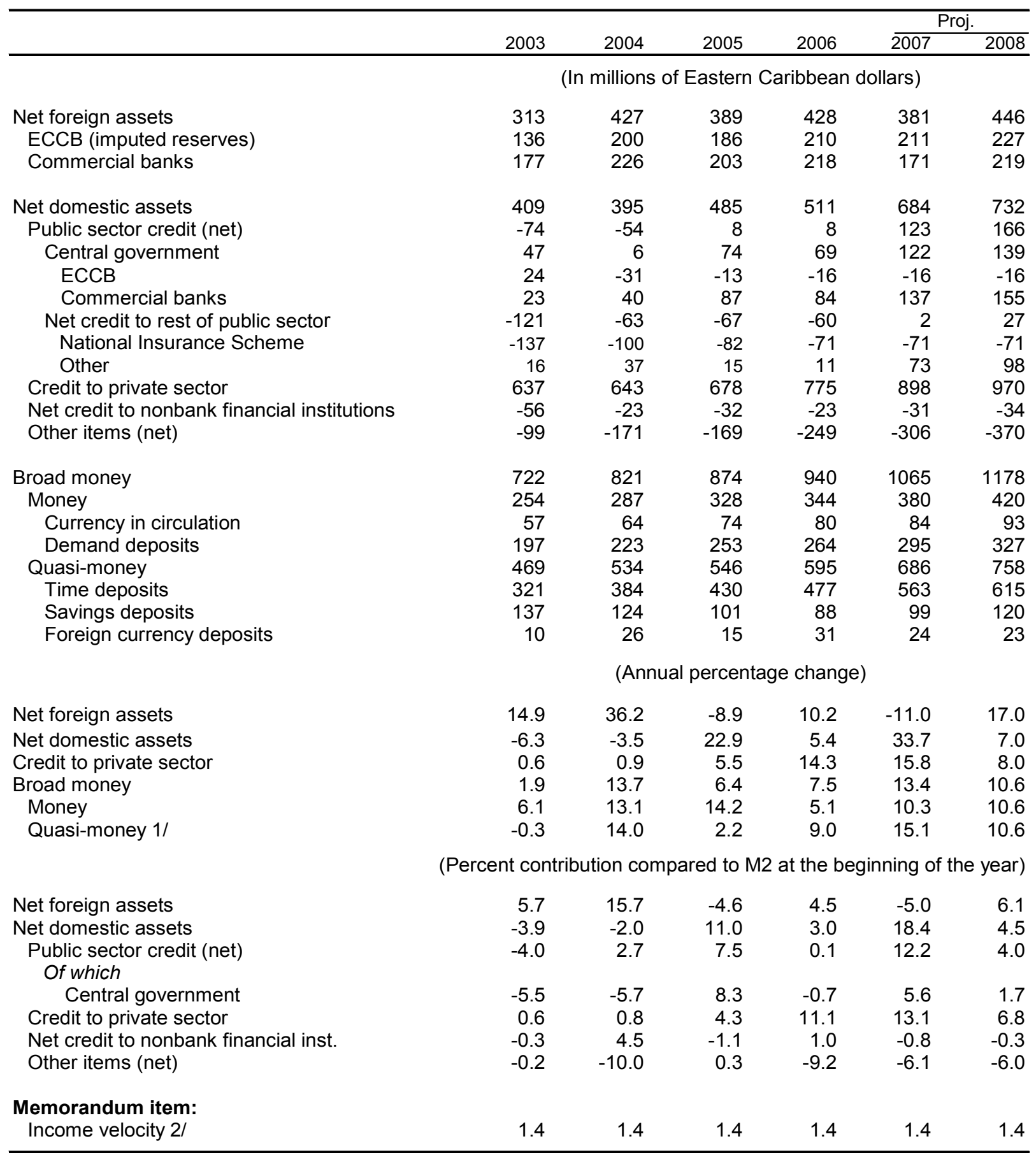

Sources: ECCB; Ministry of Finance and Planning; and Fund staff estimates.

$1 /$ Including resident foreign currency deposits.

2/ Nominal GDP at market prices divided by liabilities to the private sector. 
Table 6. St. Vincent and the Grenadines: Medium-Term Projections, 2003-12

(In percent of GDP, unless otherwise specified)

\begin{tabular}{|c|c|c|c|c|c|c|c|c|c|c|}
\hline & & & & Est. & & & Pro & & & \\
\hline & 2003 & 2004 & 2005 & 2006 & 2007 & 2008 & 2009 & 2010 & 2011 & 2012 \\
\hline & & & & & aseline & cenario & & & & \\
\hline Output and prices & & & & & & & & & & \\
\hline Real GDP growth at factor cost (in percent) & 2.8 & 6.8 & 2.6 & 6.9 & 6.7 & 5.0 & 4.8 & 5.2 & 4.7 & 4.3 \\
\hline Consumer prices, end-of-period (percent change) & 2.7 & 1.7 & 3.9 & 4.8 & 8.2 & 3.6 & 3.1 & 3.2 & 3.1 & 3.1 \\
\hline $\begin{array}{l}\text { Nonfinancial public sector } \\
\text { Central government }\end{array}$ & & & & & & & & & & \\
\hline Total revenue and grants & 31.3 & 29.6 & 30.0 & 30.8 & 31.0 & 31.6 & 31.0 & 30.3 & 30.3 & 30.3 \\
\hline Total expenditure and net lending & 34.7 & 33.1 & 35.5 & 35.7 & 35.1 & 35.0 & 34.9 & 35.0 & 35.1 & 35.2 \\
\hline Of which & & & & & & & & & & \\
\hline Wages and salaries & 13.5 & 13.1 & 13.5 & 12.9 & 12.8 & 12.5 & 12.5 & 12.5 & 12.5 & 12.5 \\
\hline Interest & 2.7 & 2.5 & 3.0 & 3.2 & 3.5 & 4.1 & 4.1 & 4.2 & 4.3 & 4.3 \\
\hline Capital expenditure & 7.9 & 7.1 & 8.2 & 8.9 & 8.9 & 7.9 & 7.9 & 7.9 & 7.9 & 7.9 \\
\hline Overall balance (cash basis) & -3.3 & -3.5 & -5.5 & -4.9 & -4.2 & -3.4 & -3.9 & -4.7 & -4.9 & -4.9 \\
\hline Of which & & & & & & & & & & \\
\hline Primary balance & -0.6 & -1.1 & -2.5 & -1.7 & -0.7 & 0.7 & 0.2 & -0.5 & -0.6 & -0.6 \\
\hline Gross public sector debt $1 / 2 /$ & 72.3 & 77.0 & 80.7 & 78.0 & 67.6 & 68.0 & 67.3 & 69.4 & 70.8 & 71.7 \\
\hline Public sector overall balance $1 /$ & -3.0 & -6.8 & -7.7 & -6.3 & -7.2 & -7.0 & -5.7 & -8.3 & -7.4 & -6.5 \\
\hline Public sector primary balance $1 /$ & -0.2 & -4.0 & -4.0 & -2.5 & -2.7 & -2.0 & -1.1 & -3.5 & -1.9 & -0.5 \\
\hline Current account balance & -20.8 & -24.8 & -22.7 & -24.4 & -26.9 & -26.8 & -23.5 & -23.6 & -21.8 & -20.6 \\
\hline & & & & II. Ac & e Polic & s Scen & & & & \\
\hline Output and prices & & & & & & & & & & \\
\hline Real GDP growth at factor cost (in percent) & 2.8 & 6.8 & 2.6 & 6.9 & 6.7 & 5.4 & 5.3 & 5.7 & 5.2 & 4.8 \\
\hline Consumer prices, end-of-period (percent change) & 2.7 & 1.7 & 3.9 & 4.8 & 8.2 & 3.6 & 3.1 & 3.2 & 3.1 & 3.1 \\
\hline Saving and investment & & & & & & & & & & \\
\hline Gross domestic investment & 33.3 & 32.2 & 32.2 & 35.4 & 39.4 & 38.9 & 35.7 & 34.7 & 35.3 & 35.1 \\
\hline Public 1/ & 10.0 & 12.9 & 12.6 & 14.3 & 17.2 & 17.7 & 15.6 & 16.4 & 13.2 & 11.1 \\
\hline Private & 23.3 & 19.3 & 19.6 & 21.1 & 22.2 & 21.2 & 20.1 & 18.3 & 22.2 & 24.0 \\
\hline Gross national saving & 12.5 & 7.4 & 9.5 & 11.0 & 12.5 & 11.9 & 12.0 & 12.0 & 14.0 & 13.9 \\
\hline Public & 6.5 & 5.3 & 3.4 & 5.2 & 5.4 & 6.1 & 7.6 & 7.5 & 8.1 & 8.8 \\
\hline Private & 6.0 & 2.2 & 6.1 & 5.8 & 7.1 & 5.8 & 4.3 & 4.5 & 5.9 & 5.1 \\
\hline Nonfinancial public sector & & & & & & & & & & \\
\hline Central government & & & & & & & & & & \\
\hline Total revenue and grants & 31.3 & 29.6 & 30.0 & 30.8 & 31.0 & 32.3 & 32.8 & 31.9 & 31.8 & 31.9 \\
\hline Total expenditure and net lending & 34.7 & 33.1 & 35.5 & 35.7 & 35.1 & 34.4 & 33.2 & 32.4 & 31.7 & 30.9 \\
\hline Of which & & & & & & & & & & \\
\hline Wages and salaries & 13.5 & 13.1 & 13.5 & 12.9 & 12.8 & 12.4 & 11.6 & 11.1 & 10.8 & 10.5 \\
\hline Interest & 2.7 & 2.5 & 3.0 & 3.2 & 3.5 & 4.1 & 3.8 & 3.5 & 3.2 & 2.9 \\
\hline Capital expenditure & 7.9 & 7.1 & 8.2 & 8.9 & 8.9 & 7.5 & 7.5 & 7.5 & 7.4 & 7.2 \\
\hline Overall balance (cash basis) & -3.3 & -3.5 & -5.5 & -4.9 & -4.2 & -2.1 & -0.4 & -0.6 & 0.1 & 1.0 \\
\hline Of which & & & & & & & & & & \\
\hline Primary balance & -0.6 & -1.1 & -2.5 & -1.7 & -0.7 & 1.9 & 3.3 & 2.9 & 3.4 & 3.9 \\
\hline Gross public sector debt $1 / 2 /$ & 72.3 & 77.0 & 80.7 & 78.0 & 67.6 & 66.2 & 62.0 & 60.0 & 56.9 & 52.8 \\
\hline Public sector overall balance 1 / & -3.0 & -6.8 & -7.7 & -6.3 & -7.2 & -5.6 & -2.3 & -4.1 & -2.3 & -0.5 \\
\hline Public sector primary balance $1 /$ & -0.2 & -4.0 & -4.0 & -2.5 & -2.7 & -0.8 & 2.4 & 0.2 & 2.1 & 4.0 \\
\hline External sector & & & & & & & & & & \\
\hline External current account & -20.8 & -24.8 & -22.7 & -24.4 & -26.9 & -26.9 & -23.6 & -22.6 & -21.2 & -21.1 \\
\hline Gross public sector external debt (end of period) & 50.9 & 53.3 & 53.8 & 48.0 & 32.8 & 33.5 & 32.7 & 31.0 & 30.0 & 29.4 \\
\hline $\begin{array}{l}\text { External public debt service } \\
\text { (In percent of exports of goods and services) }\end{array}$ & 71 & 98 & 107 & 118 & 121 & 132 & 137 & 132 & & 110 \\
\hline (In percent of exports of gooas and services) & 1.1 & 9.8 & 10.1 & 11.8 & 12.1 & 13.2 & 13.1 & 13.2 & 12.0 & 11.0 \\
\hline
\end{tabular}

Sources: ECCB; Ministry of Finance and Planning; and Fund staff estimates and projections.

1/ The consolidated public sector includes the central government, the NIS, Kingstown Board, and ten nonfinancial public enterprises. 2/ Net of intra-public sector debt (mainly central government debt to the NIS). 
Table 7. St. Vincent and the Grenadines: Indicators of External and Financial Vulnerability, 2003-07

(Annual percentage changes, unless otherwise specified)

\begin{tabular}{|c|c|c|c|c|c|}
\hline & 2003 & 2004 & 2005 & $\begin{array}{r}\text { Est. } \\
2006\end{array}$ & $\begin{array}{l}\text { Proj. } \\
2007\end{array}$ \\
\hline \multicolumn{6}{|l|}{ External indicators } \\
\hline Merchandise exports & -2.8 & -2.0 & 8.4 & -3.3 & 10.3 \\
\hline Merchandise imports & 12.1 & 12.5 & 6.7 & 12.8 & 12.7 \\
\hline Terms of trade deterioration (-) & -0.9 & -8.6 & -3.0 & -5.7 & -2.6 \\
\hline Tourism earnings & 0.2 & 4.8 & 8.7 & 9.0 & 2.3 \\
\hline Banana export earnings & -25.2 & 10.0 & -8.9 & 6.5 & -3.3 \\
\hline Current account balance (in percent of GDP) & -20.8 & -24.8 & -22.7 & -24.4 & -26.9 \\
\hline $\begin{array}{l}\text { Capital and financial account balance (in percent of GDP) 1/ } \\
\text { Of which }\end{array}$ & 20.7 & 30.9 & 22.0 & 26.8 & 36.2 \\
\hline Foreign direct investment (in percent of GDP) & 14.4 & 15.9 & 9.2 & 19.1 & 18.0 \\
\hline \multicolumn{6}{|l|}{ Gross international reserves of the ECCB } \\
\hline In millions of U.S. dollars & 539.9 & 632.4 & 600.8 & 696.0 & 749.5 \\
\hline In percent of broad money & 19.8 & 20.5 & 17.9 & 18.6 & 18.6 \\
\hline \multicolumn{6}{|l|}{ Gross imputed reserves } \\
\hline In millions of U.S. dollars & 50.4 & 74.2 & 68.8 & 77.9 & 78.0 \\
\hline In percent of short-term liablilities & 148.5 & 143.2 & 132.5 & 229.2 & 263.8 \\
\hline Commercial banks' net foreign assets (in millions of U.S. dollars) & 65.6 & 83.9 & 75.2 & 80.7 & 63.3 \\
\hline External public debt (in percent of GDP) & 50.9 & 53.3 & 53.8 & 48.0 & 32.8 \\
\hline \multicolumn{6}{|l|}{ External debt service (in percent of exports of goods and } \\
\hline $\begin{array}{l}\text { nonfactor services) } \\
\text { Of which }\end{array}$ & \multicolumn{2}{|c|}{ Of which } & 10.7 & 11.8 & 12.1 \\
\hline Interest & 3.1 & 3.9 & 4.9 & 5.5 & 6.2 \\
\hline \multicolumn{6}{|l|}{ Nominal exchange rate (E.C. dollars per U.S. dollar, } \\
\hline Real effective exchange rate depreciation (-), end period & -7.3 & -3.6 & 0.1 & -0.6 & $\ldots$ \\
\hline \multicolumn{6}{|l|}{ Financial indicators } \\
\hline Broad money & 1.9 & 13.7 & 6.4 & 7.5 & 13.4 \\
\hline Credit to the private sector & 0.6 & 0.9 & 5.5 & 14.3 & 15.8 \\
\hline \multicolumn{6}{|l|}{ Prudential indicators (in percent) $2 /$} \\
\hline Capital adequacy ratio (local banks) & 11.8 & 14.7 & 17.0 & 17.9 & 17.7 \\
\hline NPLs to total loans ratio & 11.1 & 9.6 & 5.3 & 4.3 & 2.9 \\
\hline \multicolumn{6}{|l|}{ Of which } \\
\hline Local banks & 18.0 & 14.3 & 5.9 & 3.9 & 2.3 \\
\hline Foreign banks & 2.0 & 3.9 & 4.7 & 4.8 & 2.3 \\
\hline Loan loss provision to NPLs ratio & 34.1 & 34.3 & 38.4 & 43.6 & 53.6 \\
\hline \multicolumn{6}{|l|}{ Of which } \\
\hline Local banks & 26.9 & 29.8 & 42.5 & 58.7 & 93.2 \\
\hline Foreign banks & 119.4 & 53.5 & 32.0 & 28.6 & 26.8 \\
\hline Gross government claims to total assets ratio & 16.1 & 20.3 & 19.8 & 17.7 & 15.8 \\
\hline Foreign currency deposits to total deposits ratio & 3.0 & 4.2 & 3.8 & 6.0 & 5.4 \\
\hline Net foreign currency exposure to capital (local banks) & 320.9 & 421.9 & 313.3 & 136.4 & 83.3 \\
\hline Contingent liabilities to capital (local banks) & 135.3 & 147.3 & 73.1 & 87.5 & 48.0 \\
\hline (Pre-tax) return on average assets $3 /$ & 1.0 & 1.2 & 2.4 & 2.0 & 0.5 \\
\hline Three-month treasury bill rate $4 /$ & 5.7 & 4.6 & 4.8 & 5.6 & 5.8 \\
\hline
\end{tabular}

Sources: ECCB; Ministry of Finance and Planning; and Fund staff estimates and projections.

$1 /$ Includes errors and omissions.

2/ As of end-September 2007.

3/ Quarterly return for end-September 2007.

4/ Average up to end-November 2007. 
Table 8. St. Vincent and the Grenadines: Public Sector Debt, 2003-06 1/

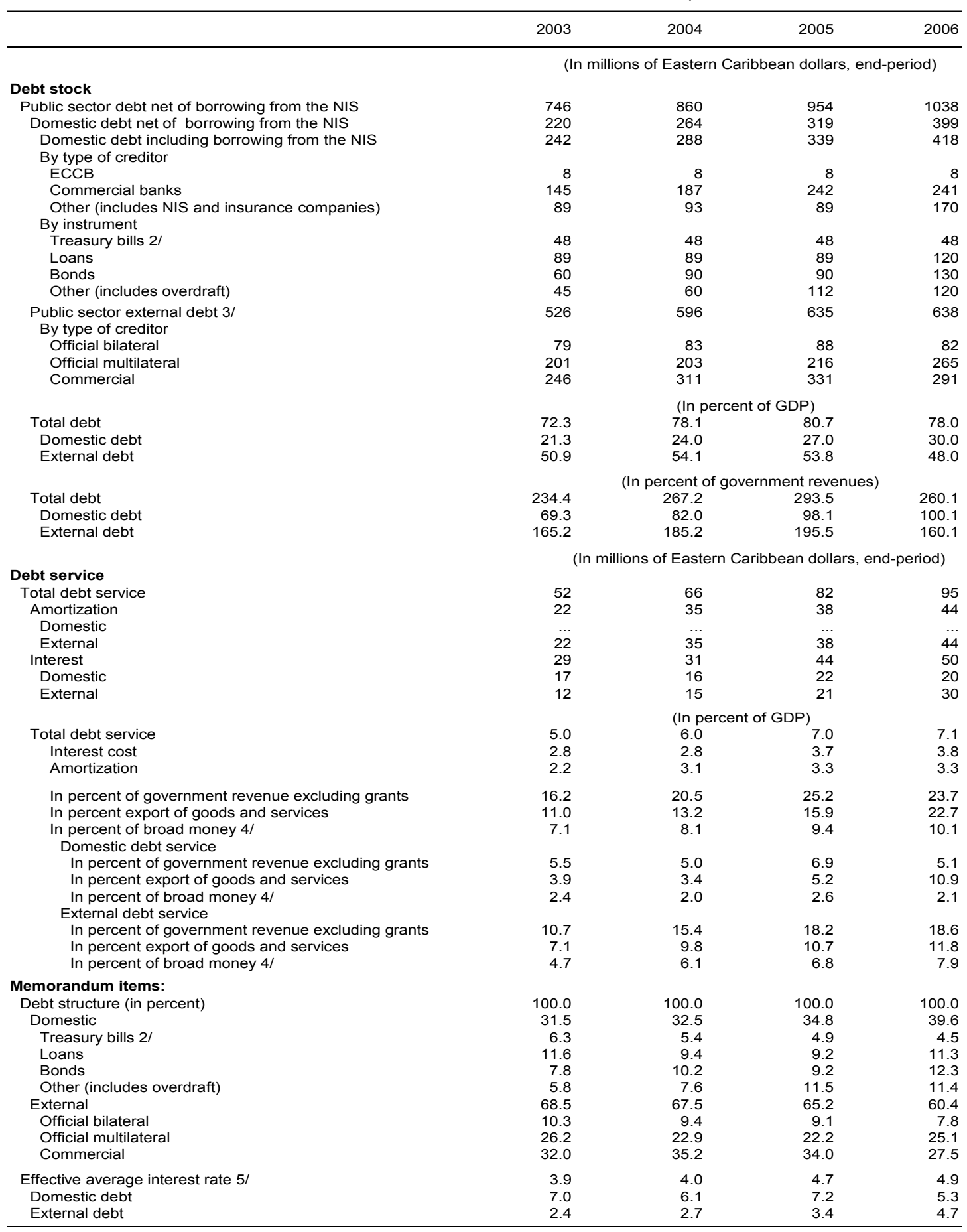

Sources: Ministry of Finance and Planning; and Fund staff estimates.

$1 /$ Net of intra-public sector debt (mainly central government debt to the NIS). The consolidated public sector includes the government, the NIS, Kingstown Board, and ten nonfinancial public enterprises.

2/ Treasury bills purchased by nonresidents on the RGSM since March 2003, are included.

3/ Includes the assumption of private debt for Ottley Hall shipyard in 1999.

$4 /$ Including foreign currency deposits.

$5 /$ Interest payment as percent of the average debt stock at beginning and end period. 
Table 9. St. Vincent and the Grenadines: Millennium Development Goals Country Profile

\begin{tabular}{|c|c|c|c|c|c|c|c|}
\hline & 1995 & 2000 & 2001 & 2002 & 2003 & 2004 & 2005 \\
\hline \multicolumn{8}{|l|}{ 1. Eradicate extreme poverty and hunger } \\
\hline Prevalence of undernourishment (percent of total population) & 27.0 & .. & .. & .. & $\ldots$ & $\ldots$ & 10.0 \\
\hline \multicolumn{8}{|l|}{ 2. Achieve universal primary education } \\
\hline Net primary enrollment ratio (percent of relevant age group) & .. & 91.1 & 93.0 & .. & .. & 94.0 & 90.0 \\
\hline Primary completion rate (percent of relevant age group) & & 72.0 & 73.5 & .. & .. & 92.9 & 92.0 \\
\hline Percentage of cohort reaching grade 5 (percent) & .. & .. & 88.0 & .. & .. & .. & .. \\
\hline \multicolumn{8}{|l|}{ 3. Promote gender equality } \\
\hline Ratio of girls to boys in primary and secondary education (percent) & .. & 107.0 & 104.3 & .. & 101.6 & 95.6 & 104.0 \\
\hline Proportion of seats held by women in national parliament (percent) & .. & 5.0 & .. & .. & 23.0 & 23.0 & $\ldots$ \\
\hline \multicolumn{8}{|l|}{ 4. Reduce child mortality } \\
\hline Under 5 mortality rate (per 1,000$)$ & 21.0 & 25.0 & 25.0 & 25.0 & 27.0 & 22.0 & 20.0 \\
\hline Infant mortality rate (per 1,000 live births) & 18.0 & 21.0 & 21.0 & 22.0 & 22.0 & 18.0 & 17.0 \\
\hline Immunization, measles (percent of children under 12 months) & 99.0 & 96.0 & 98.0 & 99.0 & 94.0 & 99.0 & 97.0 \\
\hline \multicolumn{8}{|l|}{ 5. Improve maternal health } \\
\hline Maternal mortality ratio (modeled estimate, per 100,000 live births) & .. & .. & .. & .. & .. & .. & .. \\
\hline Births attended by skilled health staff (percent of total) & .. & .. & 100.0 & .. & .. & .. & 100.0 \\
\hline \multicolumn{8}{|l|}{ 6. Combat HIVIAIDS, malaria and other diseases } \\
\hline Prevalence of HIV, female (percent ages 15-24) & .. & .. & .. & .. & .. & .. & .. \\
\hline Contraceptive prevalence rate (percent of women ages 15-49) & .. & .. & .. & .. & .. & .. & .. \\
\hline Number of children orphaned by HIV/AIDS & .. & .. & .. & .. & .. & .. & .. \\
\hline Incidence of tuberculosis (per 100,000 people) & .. & 30.6 & 28.0 & 28.9 & 29.2 & 28.5 & $\ldots$ \\
\hline Tuberculosis cases detected under DOTS (percent) & .. & 55.5 & 20.0 & .. & 38.2 & 33.0 & 39.0 \\
\hline \multicolumn{8}{|l|}{ 7. Ensure environmental sustainability } \\
\hline Forest area (percent of total land area) & .. & 15.4 & 15.4 & .. & .. & 28.0 & 28.0 \\
\hline Nationally protected areas (percent of total land area) &.. & & 21.0 & 21.3 & .. & .. & 11.3 \\
\hline CO2 emissions (metric tons per capita) & 1.2 & 1.4 & 1.4 & .. & .. & .. & .. \\
\hline Access to an improved water source (percent of population) & .. & .. & 93.0 & .. & .. & .. & .. \\
\hline Access to improved sanitation (percent of population) & .. & .. & $96.0 .$. & & .. & .. & .. \\
\hline \multicolumn{8}{|l|}{ 8. Develop a global partnership for development } \\
\hline Youth unemployment rate (percent of total labor force ages 15-24) & .. & .. & & .. & .. & .. & .. \\
\hline Fixed line and mobile telephones (per 1,000 people) & 166.6 & 240.4 & 291.9 & 318.8 & 318.8 & 641.5 & 782.0 \\
\hline Personal computers (per 1,000 people) & .. & .. & 113.0 & 119.7 & .. & 135.1 & 135.0 \\
\hline Internet users (per 1,000 people) & .. & 30.9 & .. & .. & .. & 67.6 & 84.0 \\
\hline \multicolumn{8}{|l|}{ General indicators } \\
\hline Population (thousands) & 106.3 & .. & 106.3 & 106.3 & .. & 106.3 & 106.3 \\
\hline Gross national income (in millions of U.S. dollars) & 247.5 & .. & 321.8 & 330.2 & .. & 361.4 & 375.2 \\
\hline GNI per capita (in U.S. dollars) & 2328.3 & 2800.0 & 3027.3 & 3106.3 & 3310.0 & 3400.0 & 3530.0 \\
\hline Total fertility rate (births per woman) & 2.3 & .. & 2.1 & 2.1 & 2.1 & 2.1 & .. \\
\hline Life expectancy at birth (years) & 72.2 & .. & 72.9 & 72.9 & 72.9 & 71.3 & 72.0 \\
\hline Aid (percent of GNI) & 18.7 & .. & 2.6 & 1.4 & .. & .. & .. \\
\hline
\end{tabular}

Sources: World Development Indicators database, September 2007; and Fund staff estimates. 


\section{Annex I. St. Vincent and the Grenadines: Medium-Term Outlook Under Alternative Fiscal Scenarios}

The risk of current fiscal policies leading to an unsustainable level of public debt remains, given the increasing pressure for capital and social spending. In the absence of prioritization of expenditures, notably in capital spending, and a determined increase in revenues, current debt dynamics are quite unfavorable.

Two fiscal scenarios are considered-baseline and active. Under the baseline, the debt stock and debt servicing costs continue to rise; under the active scenario discussed in the text, the stock of debt declines gradually over the medium term. Under both scenarios, the staff assumes that the airport would be completed by 2012 .

Baseline Scenario. The authorities continue current expansionary policies with overall deficits that are financed with commercial borrowing and some grants from nontraditional donors, such as Venezuela, Cuba, and Taiwan Province of China. Financing is assumed to continue to be available. The current financing gap for the international airport - estimated at around EC $\$ 150$ million net of expected land sales - is assumed to be borrowed by the central government. In the medium term, growth remains driven by the public sector mainly through large-scale construction, but is lower (by about $1 / 2$ of 1 percent) than under the active scenario. On the revenue side, the VAT yields additional revenues of around $1 \frac{1}{2}$ percent of GDP by 2008, the maximum corporate income tax rate is reduced to 30 percent by 2009 reducing corporate tax revenues as a share of GDP by 1 percentage point, and regular passthrough of international oil prices continues. On the expenditure side, after 2008 the wage bill as a share of GDP remains constant, while capital expenditures remain at around 8 percent of GDP. Under this scenario, the primary balance would remain in deficit (peaking at $3 \frac{1}{2}$ percent of GDP in 2010), and public debt would reach about 72 percent of GDP by 2012.

Active Scenario. The government would not incur any additional borrowing related to the international airport after 2008. Over the medium term, revenue measures would focus on: (i) the introduction of market valuation-based property taxes in 2009 with an expected additional yield of $1 / 2$ of 1 percent of GDP; (ii) efficiency gains in customs collections, and (iii) the gradual reduction by 2012 of the corporate income tax from 37.5 to 30 percent along with the gradual reduction of tax concessions (revenue neutral). Additional grants are expected from Taiwan Province of China and the European Union. On the expenditure side, in order to create room for planned additional social spending, growth in the real wage bill would be minimal (by holding real wages and the number of civil servants constant). Reforms to the public service pension system are adopted yielding estimated savings of 0.2 percent of GDP, while capital expenditure would be reduced by the elimination or postponement of low-priority projects, although it would still remain above its long-run average of 6.6 percent of GDP.

With the impetus from public sector capital projects and greater activity in the private sector, the underlying growth rate is expected to accelerate to about $43 / 4$ percent over the medium term. Under this scenario, public debt would decline to about 53 percent of GDP by 2012. 


\section{Annex II. Summary of Appendices}

\section{Fund Relations}

St. Vincent and the Grenadines does not have outstanding obligations to the Fund. St. Vincent and the Grenadines is a member of the Eastern Caribbean Central Bank (ECCB), which manages monetary policy and the exchange system for its eight members. The common currency, the Eastern Caribbean dollar, has been pegged to the U.S. dollar at the rate of EC $\$ 2.70$ per U.S. dollar since July 1976. St. Vincent and the Grenadines has accepted the obligations of Article VIII, Sections 2, 3, and 4, and maintains an exchange system free of restrictions on the making of payments and transfers for current international transactions. The last Article IV consultation was concluded by the Executive Board on January 17, 2007 (IMF Country Report No. 07/367). Several missions from the Caribbean Regional Technical Assistance Centre (CARTAC) and the Fiscal Affairs Department (FAD) have visited St. Vincent and the Grenadines since the beginning of 2006 to assist the authorities.

\section{Relations with the World Bank Group}

In September 2005, the Eastern Caribbean Sub-Region Country Assistance Strategy (CAS) for FY 2006-09 was presented to the Board of the World Bank. The strategy supports the sub-region's development agenda through two main pillars: (1) stimulating growth and improving competitiveness; and (2) reducing vulnerability by promoting greater social inclusion and strengthening disaster risk management. There are four active World Bank projects in St. Vincent and the Grenadines with a net commitment of approximately US\$14.44 million.

\section{Relations with the Caribbean Development Bank}

St. Vincent and the Grenadines has continued to receive financing from the Caribbean Development Bank (CDB) mostly for infrastructure and human resource development. As of November 30, 2007, CDB has approved loans totalling US\$157.6 million, of which US\$30.4 million are undisbursed.

\section{Statistical Issues}

St. Vincent and the Grenadines participates in the Fund's General Data Dissemination System (GDDS). While in areas central to surveillance - notably central government accounts, indicators of the financial sector and external sector accounts - the data are adequate for surveillance purposes, information on the rest of the public sector and nonbank financial intermediaries is limited. Major improvements are needed to facilitate effective surveillance, particularly in the coverage of national accounts (especially the tourism sector and related services), and on data used to monitor labor markets. 


\section{Annex III. St. Vincent and the Grenadines: Analytical Work}

Analytical work on St. Vincent and the Grenadines is shaped by the analytical contributions for the Eastern Caribbean Currency Union (ECCU) Policies Discussions, and is published as ECCU Selected Issues papers, and later as IMF Working Papers.

Outreach activities traditionally include the presentation of staff's preliminary analytical work to the authorities, civil society, academics and the general public in St. Vincent and the Grenadines.

Ongoing Analytical Work (to be published as 2007 ECCU Selected Issues chapters and IMF Working Papers in 2008):

- Assessing Exchange Rate Competitiveness in the Eastern Caribbean Currency Union

- Price Dynamics in the Eastern Caribbean Currency Union

- The ECCB: Challenges to an Effective Lender of Last Resort

- How Vulnerable is the Eastern Caribbean Currency Union to a Banking Crisis?

- Tourism Demand in Small-Island Economies

- Corporate Income Tax Competition in the Caribbean

- Can the ECCU Afford to Grow Old?

- Financing Universal Health Care: Lessons for the Eastern Caribbean and Beyond.

\section{Background Notes on St. Vincent and the Grenadines}

Health Issues in St. Vincent and the Grenadines

Pricing Policy for Petroleum Products

Exchange Rate Issues and Tourism Competitiveness in St. Vincent and the Grenadines

Erosion of Banana Preferences

Past Analytical Work (2006 ECCU Selected Issues papers, unless otherwise denoted)

- The Caribbean: From Vulnerability to Sustained Growth (2006 IMF book)

- Income Dispersion and Co-Movements in the Eastern Caribbean Currency Union

- The Macroeconomic Impact of Trade Preference Erosion on the Windward Islands

- The Size of the Informal Economy in the Caribbean

- Social Security in the Eastern Caribbean Currency Union

- Domestic Investment and the Cost of Capital 


\section{ST. VINCENT AND THE GRENADINES}

\section{Staff Report for the 2007 Article IV Consultation-Informational Annex}

Prepared by the Western Hemisphere Department

January 7, 2007

Contents

Appendices

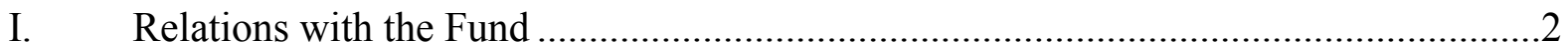

II. Relations with the World Bank Group............................................................4

III. Relations with the Caribbean Development Bank ................................................

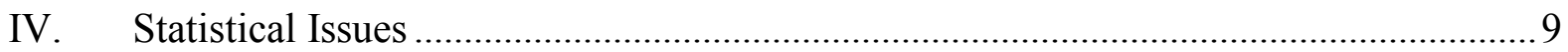


Appendix I. St. Vincent and the Grenadines: Relations with the Fund

(As of November 31, 2007).

I. Membership Status: Joined: December 28, 1979; Article VIII

\section{General Resources Account:}

Quota

Fund holdings of currency

Reserve Position

Holdings Exchange Rate

III. SDR Department:

Net cumulative allocation

Holdings

\section{Outstanding Purchases and Loans: None}

\section{Latest Financial Arrangements: None}

\section{Projected Payments to Fund: None}

VII. Exchange Rate Arrangement: St. Vincent and the Grenadines is a member of the Eastern Caribbean Currency Union, which has a common central bank (the Eastern Caribbean Central Bank) and currency (the Eastern Caribbean dollar). Since July 1976, the Eastern Caribbean dollar has been pegged to the U.S. dollar at the rate of EC\$2.70 per U.S. dollar. St. Vincent and the Grenadines has accepted the obligations of Article VIII, Sections 2, 3, and 4. St. Vincent and the Grenadines maintains an exchange system free of restrictions on the making of payments and transfer for current international transactions.

VIII. Safeguards Assessment: Under the Fund's safeguards assessment policy, the Eastern Caribbean Central Bank (ECCB), of which St. Vincent and the Grenadines is a participating government, is subject to a full safeguards assessment under a four-year cycle. The most recent assessment was completed in July 2007, and concluded that the ECCB continues to have appropriate control mechanisms in place, which have strengthened since the first safeguards assessment completed in 2003. ECCB management places emphasis on good governance and sound controls, and has enhanced the bank's transparency and accountability since the last assessment, including the publications of financial statements that comply with International Financial Reporting Standards. The assessment made some recommendations to sustain the ECCB's safeguards framework going forward.

IX. Last Article IV Consultation: St. Vincent and the Grenadines is currently on the 12-month cycle. The last Article IV consultation was concluded by the Executive Board on January 17, 2006; the relevant documents are IMF Country Report No. 07/367 and IMF Country Report No. 07/368. 
X. Technical Assistance (January 2006- ): Several missions from the Caribbean Regional Technical Assistance Centre (CARTAC) have visited St. Vincent and the Grenadines since the beginning of 2006 to assist the authorities.

In the area of public finance, CARTAC assisted with the introduction of the VAT and excise taxes at all different stages. CARTAC has also provided technical assistance in statistics to develop export-import prices, national accounts, and balance of payments statistics. On the financial front CARTAC provided technical assistance to review and upgrade the International Insurance Act, and to develop regulations for Credit Unions. 


\section{Appendix II. St. Vincent and the Grenadines: Relations with the World Bank Group}

(November 30, 2007)

The World Bank's Management presented to its Board the Eastern Caribbean Sub-Region Country Assistance Strategy (CAS), on September 13, 2005. The World Bank Group's strategy for the four years covered by this CAS (FY 2006-09) supports the sub-region's development agenda through two main pillars: (1) stimulating growth and improving competitiveness; and (2) reducing vulnerability, by promoting greater social inclusion and strengthening disaster risk management. Recognizing the Organization of Eastern Caribbean States (OECS) countries' weakened creditworthiness due to high debt ratios, Bank activities will focus on leveraging available donor grant financing. Following the recommendations of the recently completed growth and competitiveness study for the OECS, IBRD and IDA support would focus on providing technical and financial assistance for interventions to support the two main pillars. An indicative Base Case lending scenario consists of about US\$51.3 million in IDA resources for the four OECS blend countries (Dominica, Grenada, St. Lucia and St. Vincent and the Grenadines). This amount includes the estimated IDA country allocations for each of the four countries during FY 2006-09, and an IDA Regional allocation of US\$15.2 million for two regional projects: US\$12 million for Catastrophe Risk Insurance and US\$3.2 million for Infrastructure and Utilities Reform.

\section{Projects}

There are four active World Bank projects in St. Vincent and the Grenadines for a net commitment of approximately US\$14.44 million.

The OECS Catastrophe Insurance Project was approved in March, 2007 for US\$0.7 million. The objective of the project is to reduce the participating OECS governments' financial vulnerability to natural disasters through insurance coverage against earthquakes and hurricanes. This will be achieved through the establishment of the Caribbean Catastrophe Risk Insurance Facility (CCRIF) and the financing of catastrophe insurance coverage from the Facility. The project will include the following two components:

(a) payment of entrance fee; and (b) payment of annual insurance premium for the first three years. The objective of the first component is to assist the participating OECS countries to join the CCRIF through the financing of the entrance fee. This fee is equal to the first year's insurance premium. The aim of the second component is to assist the participating OECS countries to purchase the catastrophe insurance coverage offered by the CCRIF during the first three years. 
The Telecommunications \& ICT Development Project, approved in September 2005, aims at improving the access, quality, and use of telecommunications and ICT services to achieve socioeconomic development in the OECS. The project has the following four components: Component (1) will strengthen the national and regional regulatory frameworks and promote additional competition in the telecommunications sector. Emphasis will be given to capacity building of Eastern Caribbean Telecommunications Authority (ECTEL) and the National Telecommunications Regulatory Commissions (NTRCs) by providing them with assistances to revise the regional and national sector legislation, and develop a modem interconnection regime. Component (2) will review current universal access policy, create related guidelines, and provide financial support to establish a Universal Service Fund (USF). Component (3) will improve growth and competitiveness in ICT-enabled services through utilization of broadband infrastructure. Component (4) will finance management and administration of the overall project. The project will finance related technical assistance by providing complementary resources.

The St. Vincent and the Grenadines Education Reform Project was approved in June 2004 for US\$6.2 million. The overall objective of this project is to build human capital which, in turn, will contribute to the diversification of the economy and more sustainable growth. This objective will be achieved by: (i) increasing equitable access to secondary education; (ii) improving the quality of the teaching and learning process, with more direct interventions at the school level and a focus on student-centered learning, and (iii) strengthening management of the sector and governance of schools.

The HIV/AIDS Prevention and Control Program, which was approved in July 2002, is funded under the Multi-Country Adaptable Program Loan for the Caribbean Region, with the following objectives: (i) curbing the spread of HIV/AIDS epidemic; (ii) reducing the morbidity and mortality attributed to HIV/AIDS; (iii) improving the quality of life for persons living with HIV/AIDS (PLWAs); and (iv) developing a sustainable organizational and institutional framework for managing the HIV/AIDS epidemic over the longer term. The Bank's support to St. Vincent and the Grenadines under this project is for US\$7.0 million.

\section{ECONOMIC AND SECTOR WORK}

The Bank has completed a series of analytical work relating to: public sector capacity in the OECS including the Institutional and Organizational Capacity Review, the OECS Procurement Assessment Review, the OECS Financial Accountability Assessment, and an Infrastructure Services Studies. In conjunction with the IMF, a Financial Sector Assessment Program (FSAP) was completed in early 2004. The Bank also recently completed an OECS study on Growth and Competitiveness, a Caribbean Air Transport Rationalization report, and a Caribbean Crime and Violence study. Work is ongoing on an OECS Private Sector Financing Study. For St. Vincent and the Grenadines specifically, the Bank recently completed an Analysis of Fiscal Issues, which examines the management and allocation of public expenditure. 
VI. Financial Relations

(In millions of U.S. dollars)

\begin{tabular}{lccc}
\hline Operation & Original Principal & Disbursed $^{*}$ & Undisbursed $^{*}$ \\
\hline CATASTROPHE INSURANCE & 0.70 & 0.42 & 0.32 \\
TELECOM AND ICT DEVELOPMENT & 0.54 & 0.17 & 0.42 \\
EDUCATION REFORM PROJECT & 6.20 & 1.28 & 5.31 \\
HIV/AIDS PREVENTION AND CONTROL & 7.00 & 2.06 & 5.30 \\
\hline Total & 14.44 & 3.93 & 11.35 \\
\hline
\end{tabular}

* Amounts may not add up to Original Principal due to changes in the SDR/US exchange rate since signing.

Disbursements and Debt Service (Fiscal Year Ending June 30)

\begin{tabular}{lccccccccc}
\hline & 2000 & 2001 & 2002 & 2003 & 2004 & 2005 & 2006 & 2007 & $2008^{* *}$ \\
\hline Total disbursements & 0.02 & 0.36 & 1.46 & 1.73 & 1.20 & 2.48 & 4.55 & 3.06 & 0.57 \\
Repayments & 0.13 & 0.12 & 0.12 & 0.29 & 0.14 & 0.27 & 0.30 & 0.31 & 0.26 \\
Net Disbursements & 0.10 & 0.24 & 1.34 & 1.44 & 1.06 & 2.21 & 4.25 & 2.75 & 0.30 \\
Interest and fees & 0.00 & 0.03 & 0.07 & 0.12 & 0.13 & 0.19 & 0.21 & 0.30 & 0.15 \\
\hline
\end{tabular}

**Data as of Nov. 30, 2007. 


\section{Appendix III. St. Vincent and the Grenadines: Relations with the Caribbean Development Bank}

(As of November 30, 2007)

CDB has approved loans totalling US\$157.6 million, of which US\$30.4 million are undisbursed.

\section{Major Projects:}

1. Third Power Project-is geared towards improving the operational capability and reliability of St. Vincent Electricity Services Limited (VINLEC) in order to meet the projected demand for electricity to the end of 2008.

2. Basic Education Project (Second Loan) - is to assist the Government of St. Vincent and the Grenadines in enhancing the learning environment through improvements in delivery of pre-primary and basic education within St. Vincent and the Grenadines. Components include the construction of four schools; the upgrading of knowledge, skills and competencies of education managers, planners and supervisors; and professional development of teachers, trainers, principals and other key school personnel.

3. $3^{\text {rd }}$ Road Project-Windward Highway - to reconstruct approximately 23 kilometres of the Windward Highway; the realignment of the road at six locations; widening and lining of the Byera tunnel to provide pedestrian access; and rehabilitation of 13 bridges.

4. $\quad 3^{\text {rd }}$ Road Project-Windward Highway (Add. Loan)— to construct approximately 3 kilometres of highway to bypass the site of the new international airport at Argyle.

5. Support For The Transformation Process-LIAT (1974) Limited-involving the financing of activities associated with the financial and institutional restructuring of LIAT.

6. Student Loan Scheme (Sixth Loan) — to provide loans to students for upgrading skills at the professional, technical and vocation levels. 


\section{CURRENT PORTFOLIO}

(In millions of U.S. dollars)

\begin{tabular}{lcc}
\hline & Approved & Undisbursed \\
\hline Third Power Project & 18.3 & 6.9 \\
Basic Education (second loan) & 17.6 & 12.0 \\
$3^{\text {rd }}$ Road Project—Windward Highway & 10.6 & 0.2 \\
$3^{\text {rd }}$ Road Project—Windward Highway(Add. Loan) & 5.2 & 5.2 \\
Support For The Transformation Process - & 5.5 & 3.6 \\
LIAT (1974) Limited & 3.5 & 1.4 \\
Student Loan Scheme (sixth loan) & 2.4 & 0.4 \\
Line of Credit (third loan) & & \\
\hline
\end{tabular}

II. LOAN DISBURSEMENT

(in millions of U.S. dollars)

\begin{tabular}{|c|c|c|c|c|c|}
\hline & $\mathbf{2 0 0 3}$ & $\mathbf{2 0 0 4}$ & $\mathbf{2 0 0 5}$ & $\mathbf{2 0 0 6}$ & $\mathbf{2 0 0 7}^{\mathbf{1}}$ \\
\hline Net Disbursement & 0.96 & 1.52 & 4.01 & 8.31 & 10.15 \\
\hline Disbursement & 3.88 & 4.61 & 7.35 & 11.35 & 12.72 \\
\hline Amortization & 2.92 & 3.09 & 3.34 & 3.04 & 2.57 \\
\hline Interest and charges & 1.92 & 1.99 & 2.11 & 2.60 & 3.05 \\
\hline Net resource flow & -0.96 & -0.47 & 1.90 & 5.71 & 7.10 \\
\hline
\end{tabular}

1/ As of November 30. 


\section{Appendix IV. St. Vincent and the Grenadines-Statistical Issues}

(As of November 30, 2007)

St. Vincent and the Grenadines participates in the General Data Dissemination System (GDDS) since September 2000, and its metadata are posted on the Dissemination Standards Bulletin Board. Statistical databases remains weak in terms of coverage, consistency, periodicity, and timeliness. While in areas central to surveillance-notably central government accounts, indicators of the financial sector and external sector accounts - the data are adequate for surveillance purposes, information on the rest of the public sector and nonbank financial intermediaries is limited. Major improvements are needed to facilitate effective surveillance, particularly in the coverage of national accounts (especially the tourism sector and related services), and on data used to monitor labor markets. Efforts to address the weaknesses in the statistical base have been hampered by low response rates to surveys (less than 50 percent), and high turnover of staff.

\section{National accounts}

GDP by industry is provided with a one-year lag, with inadequate coverage of economic activity in the informal sector. There is a need to upgrade national accounting methodology from the 1968 System of National Accounts to the 1993 System of National Accounts. In addition, data on GDP broken down by type of expenditure are not available at constant prices, while data at current prices are not reliable due to weaknesses in estimating gross capital formation. Private final consumption expenditure is estimated as a residual. CARTAC is now finalizing a project for improving the national accounts though the development of Supply and Use tables. Data generated will be used to revise and rebase the GDP series. In October 2007 CARTAC also launched a project for strengthening tourism statistics in the OECS, including St. Vincent and the Grenadines. The project covers the core tourism datasets relating to visitor arrivals, visitor expenditure, tourist accommodation and statistics for other key tourism-related enterprises. The project will also seek to standardize and harmonize tourism concepts, definitions and classification schemes across these countries.

\section{Prices}

Data on the consumer price index (CPI) are reported regularly with a one-month lag. CARTAC, as part of the Fund-assisted program on Constructing Weights for the Harmonized Consumer Price Index in the Eastern Caribbean Currency Union (ECCU), has assisted in linking the 1981-based to the 2001-based CPI series. The Statistical Office (SO) is currently undertaking a combined Country Poverty Assessment and Household Budgetary Survey.

\section{Labor}

The SO has not published official data on unit labor costs and employment. Results of the 2001 population census have been analyzed and published. 


\section{Public finance}

Due to delays in reporting capital expenditures by some ministries, quarterly revenue and expenditure data for the central government are provided to the Fund with some lag. Discrepancies exist between the fiscal and monetary accounts, between above and below the line for budget data, and between financing and debt data. Although domestic debt figures are now available following implementation of the Commonwealth Secretariat - Debt Recording and Management System, the domestic debt amortization figures are incomplete. The financial reports of public enterprises are not timely, with about a two-year lag.

The IMF publishes annual data for the consolidated general government in the GFS Yearbook, with the 2007 edition showing annual data to 2004. No new data have been received for more recent years. Only cash data are shown, with a detailed classification of revenue and a functional, but not economic, classification of expenditure. No financing information is provided. The 2007 GFS Yearbook shows no balance sheet data but the 2004 edition published domestic and foreign liabilities for 2001.

\section{Monetary statistics}

Monetary data are compiled by the Eastern Caribbean Central Bank (ECCB) on a monthly basis. The data are reported regularly to the Fund, although the timeliness of data could be improved. There is also a need to improve the institutional coverage that currently only comprises the ECCB and commercial banks. Full implementation of recommendations made by the monetary and financial statistics missions conducted in August 2003 and December 2005 should ensure consistency with international best practice.

While noting some recent improvements, the April 2007 data ROSC mission identified some shortcomings in the ECCB's monetary statistics, which have a potential for detracting from the accurate and timely analysis of monetary and financial developments and formulation of appropriate policies. In particular, (i) the methodological soundness of monetary statistics can be improved by adopting internationally accepted concepts and definitions, expanding their institutional coverage, and revising the classifications of financial instruments and the basis for recording; (ii) the transparency of monetary statistics can be improved, for example, by releasing monetary data to all users at the same time and strengthening the validation of the disseminated data; (iii) the timeliness of the dissemination of the data on broad money and credit aggregates can be improved to meet best international practices; and (iv) the access to officially disseminated monetary data and metadata can be improved.

\section{Balance of payments}

Estimates are currently provided on an annual basis by the ECCB, using a format that is not fully consistent with BPM5. There is a need to improve the compilation of capital and financial account transactions in the balance of payments. In addition, the recording of the stock of private and public debt should be improved. 
St. Vincent and the Grenadines: Table of Common Indicators Required for Surveillance

(As of December 12, 2007)

\begin{tabular}{|c|c|c|c|c|c|}
\hline & $\begin{array}{c}\text { Date of Latest } \\
\text { Observation }\end{array}$ & Date Received & $\begin{array}{l}\text { Frequency of } \\
\text { Data }^{6}\end{array}$ & $\begin{array}{l}\text { Frequency of } \\
\text { Reporting }\end{array}$ & $\begin{array}{l}\text { Frequency of } \\
\text { Publication }^{6}\end{array}$ \\
\hline Exchange Rates & Fixed Rate & n.a. & n.a. & n.a. & n.a. \\
\hline $\begin{array}{l}\text { International Reserve Assets and Reserve Liabilities of the Monetary } \\
\text { Authorities } 1\end{array}$ & 09/2007 & $11 / 2007$ & M & Q & Q \\
\hline Reserve/Base Money & $9 / 07$ & $12 / 3 / 07$ & M & Q & Q \\
\hline Broad Money & $9 / 07$ & $12 / 3 / 07$ & M & Q & Q \\
\hline Central Bank Balance Sheet & $9 / 07$ & $12 / 3 / 07$ & M & Q & Q \\
\hline Consolidated Balance Sheet of the Banking System & $9 / 07$ & $12 / 3 / 07$ & M & Q & Q \\
\hline Interest Rates $^{2}$ & $9 / 07$ & $12 / 3 / 07$ & M & $\mathrm{Q}$ & $\mathrm{Q}$ \\
\hline Consumer Price Index & $9 / 07$ & $12 / 11 / 07$ & M & M & M \\
\hline $\begin{array}{l}\text { Revenue, Expenditure, Balance and Composition of Financing }{ }^{3}-\text { General } \\
\text { Government }{ }^{4}\end{array}$ & 09/2007 & $10 / 2007$ & Q & Q & A \\
\hline $\begin{array}{l}\text { Revenue, Expenditure, Balance and Composition of Financing }{ }^{3}-\text { Central } \\
\text { Government }\end{array}$ & $09 / 2007$ & $10 / 2007$ & Q & Q & A \\
\hline Stocks of Central Government and Central Government-Guaranteed Debt ${ }^{5}$ & $09 / 2007$ & $10 / 2007$ & A & A & A \\
\hline External Current Account Balance & 2006 & $11 / 2007$ & A & A & A \\
\hline Exports and Imports of Goods and Services & $12 / 06$ & $10 / 2007$ & M & M & Q \\
\hline GDP/GNP & 2006 & $10 / 2007$ & A & A & A \\
\hline Gross External Debt & 09/2007 & $10 / 2007$ & A & A & A \\
\hline
\end{tabular}

${ }^{1}$ Includes reserve assets pledged or otherwise encumbered as well as net derivative positions.

${ }^{2}$ Both market-based and officially determined, including discount rates, money market rates, rates on treasury bills, notes and bonds.

${ }^{3}$ Foreign, domestic bank, and domestic nonbank financing.

${ }^{4}$ The general government consists of the central government (budgetary funds, extra budgetary funds, and social security funds) and state and local governments.

${ }^{5}$ Including currency and maturity composition.

${ }^{6}$ Daily (D), Weekly (W), Monthly (M), Quarterly (Q), Annually (A); Irregular (I); Not Available (NA) 


\title{
INTERNATIONAL MONTETARY FUND
}

\section{ST. VINCENT AND THE GRENADINES}

\section{External and Public Debt Sustainability Analysis}

\author{
Prepared by the Staff of the International Monetary Fund
}

January 7, 2008

\begin{abstract}
St. Vincent and the Grenadines' debt sustainability analysis (DSA) suggests that a key challenge will be achieving sound public finances to ensure debt sustainability, particularly given the uncertainties relating to the new international airport financing. Staff estimates show that if sizable government borrowing is needed to finance the construction of the new international airport, public debt would be on a rising and potentially unsustainable path. St. Vincent and the Grenadines' external debt distress rating is moderate.
\end{abstract}

\section{BACKGROUND}

23. Macroeconomic outcomes have strengthened significantly in recent years. Real GDP growth averaged 51/2 percent during 2004-06, and reached close to 7 percent in 2006. Activity was sustained by construction, tourism and government services; partly related to preparations for the Cricket World Cup (CWC). Fiscal imbalances also improved in 2006, but remain high. Total tax revenues were strong, buoyed by higher stamp taxes and more frequent pass-through of oil prices. Current spending was lower, reflecting some reduction on wages and salaries. As a result, the overall deficit fell to 4.9 percent of GDP in 2006, but the NPV of the public sector debt remained high at around 69 percent ( 78 percent in nominal terms).

\section{UNDERLYING DSA ASSUMPTIONS}

24. The baseline scenario assumes continued current expansionary policies with overall deficits that are financed commercially and with some grants from nontraditional donors, such as Venezuela, Cuba, and Taiwan Province of China. Medium-term growth is projected at around $4 \frac{1}{4}$ percent, driven mostly by large-scale public sector construction and tourism, given the ongoing construction of the new international airport. Under this scenario, the central government primary balance improves only modestly, with a deficit of around $5 / 8$ percent of GDP by 2012. While the growth projections are similar to those in the 2006 Article IV consultation DSA, the fiscal projections are more conservative, partly reflecting the uncertainties surrounding the financing of the international airport. 


\section{Box 1. Baseline Macroeconomic Assumptions (2007-27)}

- Real GDP growth is projected to average about $4 \frac{1}{4}$ percent, which is close to the historical average (1996-2006, at around 3\%/4 percent). Inflation is projected to remain low, consistent with historical averages and the currency board arrangement.

- The primary balance of the central government is projected to improve moderately, but less than envisaged in the 2006 Article IV consultation. On the revenue side, the VAT yields additional revenues of around 1 1/2 percent of GDP by 2008 , and frequent pass-through of international oil prices continues. On the expenditure side, the wage bill as a share of GDP remains at its current level, while capital expenditures remain at around 8 percent of GDP. Under this scenario, the public sector primary deficit would remain sizable (peaking at $3 \frac{1}{2}$ percent of GDP by 2010), and the NPV of public debt would reach about 69 percent of GDP ( 72 percent in nominal terms) by 2012.

- Annual disbursements of external capital grants are expected to be around $1 \frac{1}{2}$ percent of GDP, consistent with the historical average.

- Given the ongoing repricing of risk and tightening global liquidity conditions, it is assumed that average nominal interest rates on foreign debt increase to around 7 percent.

- The current account deficit is assumed to remain high during the period when the airport is constructed and then return to a more sustainable level, due to a pickup in tourist receipts. The expansion of tourist arrivals is underpinned by an expansion of the hotel capacity of 40 percent over the medium term and the construction of the new international airport.

- $\quad$ FDI is assumed to return to its historical average of around 14 percent of GDP.

\section{Evaluation of Public Sector Debt Sustainability}

25. At end-2006 the NPV of public debt was high at about 69 percent of GDP (78 percent in nominal terms), albeit still among the lowest in the ECCU. Expansionary budgets in 2002-05 sharply raised the fiscal deficit and debt-to-GDP ratio. Fiscal imbalances remained high in 2006-07, owing to increased CWC-related capital expenditures. 
26. The NPV of external debt stood at 39 percent of GDP, and domestic debt at 30 percent of GDP. The largest share of the external debt stock is owed to multilateral and bilateral creditors (around 55 percent of total external debt), followed by commercial creditors (around 45 percent of total external debt). In the future, most new external requirements are expected to be financed through the ECCU Regional Government Securities Market (RGSM). On the domestic front, commercial banks are the most important lenders to the government.

27. An agreement with Italy to write-off the Ottley Hall debt obligation reduced St. Vincent and the Grenadines' NPV of public debt by about 31/4 percent of GDP (10 percent in nominal terms). This loan had been serviced by the Italian export agency, due to perceived malfeasance by the private builder-operator. The debt write-off, formalized in October 2007, will lower the NPV of debt to-GDP ratio to around 66 percent by end-2007 (68 percent in nominal terms).

\section{Baseline Scenario}

28. Under the baseline scenario St. Vincent and the Grenadines' NPV of public debt to GDP ratio would rise to about 69 percent by 2012 (72 percent in nominal terms), and increase further in the long term to around 82 percent of GDP by 2027 (821/2 percent in nominal terms). Similarly, the NPV of debt-to revenue ratio increases from 181 percent in 2007 to around 211 percent by 2012.

\section{Alternative Scenarios}

\section{Active scenario}

29. Under this scenario a fiscal adjustment would raise the primary surplus of the central government to 4 percent of GDP over the medium term. The adjustment would be supported by revenue measures, including: (i) the introduction of market valuation-based property taxes in 2009 with an expected additional yield of $1 / 2$ of 1 percent of GDP; (ii) efficiency gains in customs collections, and (iii) the gradual reduction by 2012 of the corporate income tax from 37.5 to 30 percent along with the gradual reduction of tax concessions (revenue neutral). It is assumed that donors would support the reform strategy, and additional grants would be provided by the European Union and Taiwan Province of China. On the expenditure side, in order to create room for planned additional social spending, growth in the real wage bill would be minimal (by holding real wages and the number of civil servants constant). This scenario also assumes that the government sells enough land to meet any additional financial needs related to the international airport after 2008. Reforms to the public service pension system are adopted yielding estimated savings of 0.2 percent of GDP, while capital expenditure would be reduced by the elimination or postponement of low-priority projects, although it would still remain above its long-run average of 6.6 percent of GDP. 
30. Under this adjustment scenario St. Vincent and the Grenadines' NPV of public debt to GDP would decline to about 55 percent by 2012 (53 percent in nominal terms)-below the 60 percent benchmark of the ECCB (Table 2, Active Scenario). The NPV of debt to GDP ratio would decline throughout the period reaching around 41 percent of GDP by 2027. All other indicators of debt sustainability would register continual improvements; particularly debt service as a share of current revenue, which would fall to around 14 percent by 2027 .

\section{Lower growth and natural disasters}

31. The sensitivity analysis shows that lower economic growth and natural disasters are the two key vulnerabilities for St. Vincent and the Grenadines' debt dynamics. Assuming that growth remains at one standard deviation below the level in the baseline scenario, the NPV of debt-to-GDP ratio reaches 115 percent of GDP by 2027 (Table 2, Scenario A3). Similarly, the impact of a natural disaster on St. Vincent and the Grenadines' debt dynamics is very significant (Table 2, Scenario A4). Under this scenario the government incurs a fiscal cost of 9 percent of GDP in 2008-10, reverting to the baseline levels thereafter. ${ }^{10}$ This shock accelerates the deterioration of the NPV of debt-to-GDP ratio which reaches 85 percent of GDP by 2012.

\section{Borrowing for the Airport}

32. Sensitivity analysis also shows the importance of containing borrowing for the construction of the new international airport. If the in-kind grants do not materialize, land sales are lower than expected, and the government needs to borrow around 50 percent of the airport cost, then by 2012 the NPV of debt-to-GDP ratio rises to 88 percent (Table 2, Scenario A5).

\section{Evaluation of External Debt Sustainability}

33. St. Vincent and the Grenadines' external debt sustainability analysis covers only public sector debt, since data on private sector external borrowing is not available. As a result, debt dynamics in the external DSA follow a similar pattern to those of the public sector DSA.

34. Under the baseline scenario the NPV of external debt gradually increases, reaching $41 \frac{1}{2}$ percent of GDP by 2027 ( 42 percent in nominal terms), but remains within the

\footnotetext{
${ }^{10}$ The actual impact of this shock could be lower given the recent participation of St. Vincent and the Grenadines in the Caribbean Catastrophe Risk Insurance Facility - a regional insurance pool organized by the World Bank.
} 
prudential threshold of 50 percent. ${ }^{11}$ The NPV of debt-to-exports ratio remains below 100 percent throughout the period, comfortably below the indicative threshold of 200 percent.

35. Sensitivity analysis shows that the level of external debt is most sensitive to a negative shock to output growth and a decline on FDI. If FDI were to fall to one standard deviation below its historical average in 2008-09, the NPV of external debt-to-GDP ratio would increase to 71 percent by 2012 (Table 4, Scenario B4) or 75 percent in nominal terms. Similarly, with output growth at one standard deviation below its historical average for 2008-09, the NPV of external debt-to-GDP ratio increases to 58 percent by 2012 (Table 4, Scenario B1) or 62 in nominal terms.

\section{Conclusion}

36. Public sector imbalances would remain high without continuous fiscal adjustment, and by 2017 the NPV of public debt-to-GDP would return to a similar level as before the Ottley Hall write-off. Staff analysis shows that with a fiscal adjustment that achieves a central government primary surplus (including grants) of around 4 percent of GDP by 2012, St. Vincent and the Grenadines would reach a nominal public debt-to-GDP ratio below 60 percent - the ECCB benchmark—by 2011.

37. St. Vincent and the Grenadines faces a moderate risk of external debt distress. The debt trajectory under the baseline scenario does not breach the NPV of debt-to-GDP indicative threshold; however, various stress tests underline the country's vulnerabilities to natural disasters, lower FDI, and lower output growth. These alternative scenarios show a substantial rise in the debt-service ratio over the projection period, and a breach of some of the debt stock thresholds.

\footnotetext{
${ }^{11}$ The DSA uses policy-dependent external debt-burden thresholds. Policy performance is measured by the Country Policy and Institutional Assessment (CPIA) index, compiled annually by the World Bank. The CPIA divides countries into three performance categories (strong, medium, and poor) based on the overall quality of macroeconomic policies, with strong performers having higher prudential thresholds than poor performers. St. Vincent and the Grenadines is classified by the CPIA as a strong performer, implying prudential thresholds on NPV of debt-to-GDP and debt-to-exports ratios of 50 and 200 percent, respectively.
} 
Table 1.St. Vincent and the Grenadines: Public Sector Debt Sustainability Framework, Baseline Scenario, 2004-27 (In percent of GDP, unless otherwise indicated)

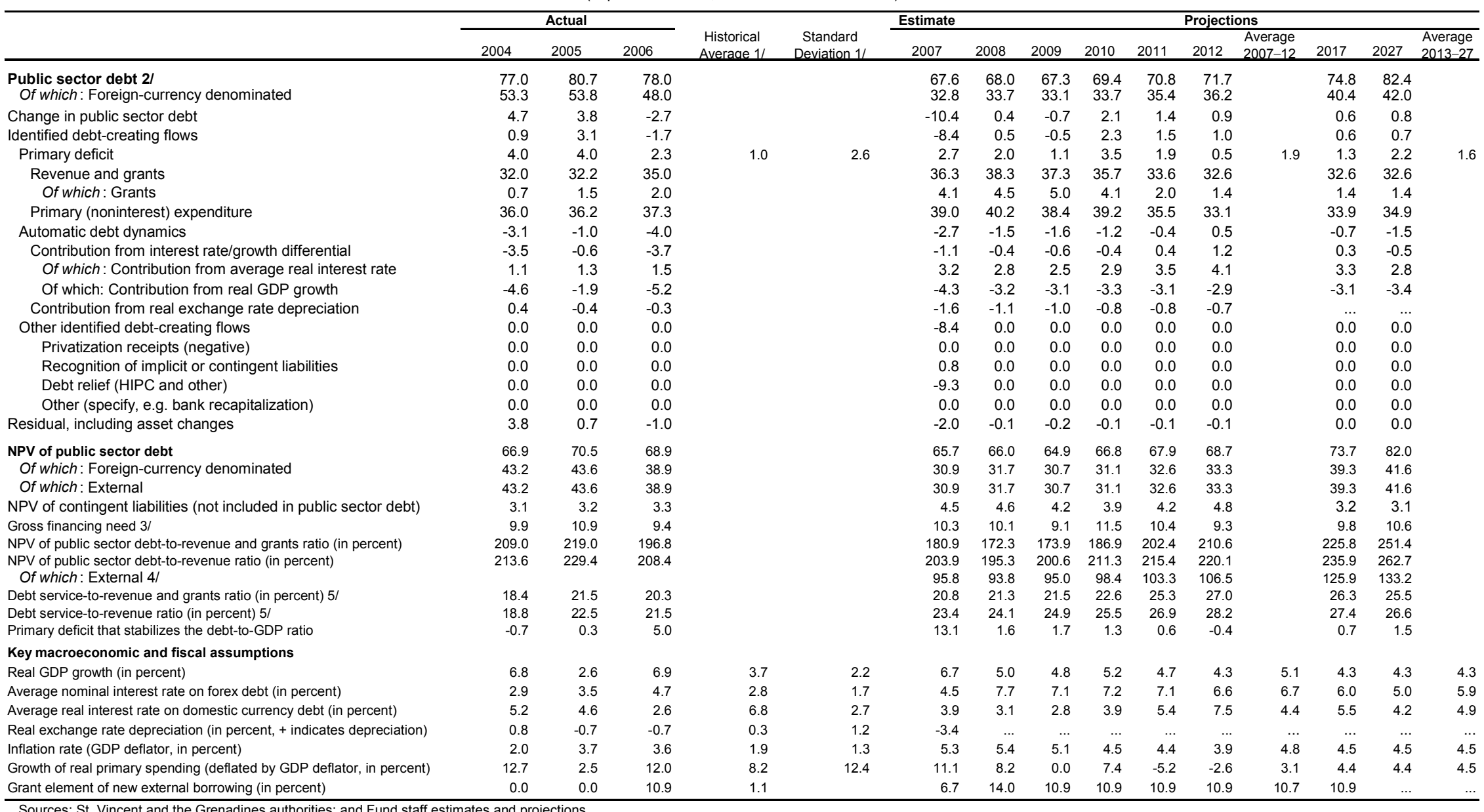

tions.

/ Historical averages and standard deviations are generally derived over the past 10 years, subject to data availability.

$2 /$ The consolidated public sector debt includes the central government, the NIS, and ten nonfinancial public sector enterprises.

3/ Gross financing need is defined as the primary deficit plus debt service plus the stock of short-term debt at the end of the last period.

$5 /$ Debt service is defined as the sum of interest and amortization of medium and long-term debt. 
Table 2.St. Vincent and the Grenadines: Sensitivity Analysis for Key Indicators of Public Debt 2007-2027

NPV of Debt-to-GDP Ratio
Baseline
Active Scenario
A. Alternative scenarios
A1. Real GDP growth and primary balance are at historical averages
A2. Primary balance is unchanged from 2007
A3. Permanently lower GDP growth $1 /$
A4. Natural Disaster $2 /$
A5. Airport Financing $3 /$
B. Bound tests
B1. Real GDP growth is at historical average minus one standard deviations in 2008-2009
B2. Primary balance is at historical average minus one standard deviations in 2008-2009
B3. Combination of B1-B2 using one half standard deviation shocks
B4. One-time 30 percent real depreciation in 2008
B5. 10 percent of GDP increase in other debt-creating flows in 2008

Projections

$\begin{array}{llllllll}2007 & 2008 & 2009 & 2010 & 2011 & 2012 & 2017 & 2027\end{array}$

A. Alternative scenarios

A1. Real GDP growth and primary balance are at historical averages

A4. Natural Disaster 2

\section{NPV of Debt-to-Revenue Ratio 4/}

Baseline

Active Scenario

\section{A. Alternative scenarios}

A1. Real GDP growth and primary balance are at historical averages

A2. Primary balance is unchanged from 2007

A3. Permanently lower GDP growth $1 /$

\section{B. Bound tests}

B1. Real GDP growth is at historical average minus one standard deviations in 2008-2009

B2. Primary balance is at historical average minus one standard deviations in 2008-2009

B3. Combination of B1-B2 using one half standard deviation shocks

B4. One-time 30 percent real depreciation in 2008

B5. 10 percent of GDP increase in other debt-creating flows in 2008

Debt Service-to-Revenue Ratio 2/

Baseline

Active Scenario

\section{A. Alternative scenarios}

A1. Real GDP growth and primary balance are at historical averages

A2. Primary balance is unchanged from 2007

A3. Permanently lower GDP growth $1 /$

\section{B. Bound tests}

B1. Real GDP growth is at historical average minus one standard deviations in 2008-2009

B2. Primary balance is at historical average minus one standard deviations in 2008-2009

B3. Combination of B1-B2 using one half standard deviation shocks

B4. One-time 30 percent real depreciation in 2008

B5. 10 percent of GDP increase in other debt-creating flows in 2008

$\begin{array}{llllllll}66 & 66 & 65 & 67 & 68 & 69 & 74 & 82 \\ 66 & 68 & 63 & 61 & 58 & 55 & 50 & 41\end{array}$

$\begin{array}{llllllll}66 & 64 & 64 & 64 & 66 & 68 & 75 & 83\end{array}$

$\begin{array}{llllllll}66 & 64 & 64 & 64 & 65 & 68 & 76 & 82\end{array}$

$\begin{array}{llllllll}66 & 66 & 66 & 69 & 72 & 74 & 87 & 115\end{array}$

$\begin{array}{llllllll}66 & 70 & 75 & 83 & 84 & 85 & 90 & 96\end{array}$

$\begin{array}{llllllll}66 & 71 & 76 & 84 & 87 & 88 & 93 & 99\end{array}$

$\begin{array}{llllllll}66 & 68 & 71 & 75 & 78 & 81 & 93 & 108\end{array}$

$\begin{array}{llllllll}66 & 67 & 68 & 70 & 72 & 73 & 79 & 84\end{array}$

$\begin{array}{llllllll}66 & 67 & 68 & 71 & 72 & 73 & 79 & 85\end{array}$

$\begin{array}{llllllll}66 & 79 & 78 & 80 & 81 & 83 & 90 & 97\end{array}$

$\begin{array}{llllllll}66 & 74 & 73 & 74 & 75 & 76 & 80 & 86\end{array}$

Sources: St. Vincent and the Grenadines authorities; and Fund staff estimates and projections.

$1 /$ Assumes that real GDP growth is at baseline minus one standard deviation divided by the square root of 20 (i.e., the length of the projection period).

2/ Assumes a fiscal cost for the government of 9 percent of GDP between 2008 and 2010.

$3 /$ Assumes in-kind grants do not materialize and the government needs to borrow 50 percent of the airport cost.

4/ Revenues are defined inclusive of grants. 
Table 3. St. Vincent and the Grenadines: External Debt Sustainability Framework, Baseline Scenario, 2004-27 1/ (In percent of GDP, unless otherwise indicated)

\begin{tabular}{|c|c|c|c|c|c|c|c|c|c|c|c|c|c|c|c|c|}
\hline & \multicolumn{4}{|c|}{ Actual } & \multirow[b]{2}{*}{$\begin{array}{l}\text { Historical } \\
\text { Average 1/ }\end{array}$} & \multirow[b]{2}{*}{$\begin{array}{l}\text { Standard } \\
\text { Deviation } 1 /\end{array}$} & \multicolumn{9}{|c|}{ Projections } & \multirow[b]{2}{*}{$\begin{array}{l}\text { Average } \\
2013-27\end{array}$} \\
\hline & 2002 & 2004 & 2005 & 2006 & & & 2007 & 2008 & 2009 & 2010 & 2011 & 2012 & $\begin{array}{l}\text { Average } \\
2007-12\end{array}$ & 2017 & 2027 & \\
\hline External debt (nominal) $2 /$ & 46.5 & 53.3 & 53.8 & 48.0 & & & 32.8 & 33.7 & 33.1 & 33.7 & 35.4 & 36.2 & & 40.4 & 42.0 & \\
\hline Of which: Public and publicly guaranteed (PPG) & 46.5 & 53.3 & 53.8 & 48.0 & & & 32.8 & 33.7 & 33.1 & 33.7 & 35.4 & 36.2 & & 40.4 & 42.0 & \\
\hline Change in external debt & -2.6 & 2.4 & 0.4 & -5.8 & & & -15.2 & 0.9 & -0.6 & 0.6 & 1.7 & 0.8 & & 0.4 & 0.3 & \\
\hline Identified net debt-creating flows & -0.5 & 5.0 & 10.7 & -0.8 & & & 6.1 & 7.4 & 6.6 & 6.6 & 5.6 & 4.4 & & 4.3 & 4.2 & \\
\hline Noninterest current account deficit & 10.2 & 23.4 & 20.9 & 22.1 & 17.4 & 8.2 & 25.0 & 24.5 & 21.3 & 21.4 & 19.6 & 18.4 & & 18.4 & 18.7 & 18.4 \\
\hline Deficit in balance of goods and services & 10.0 & 21.2 & 20.7 & 23.6 & & & 26.4 & 25.7 & 22.4 & 22.5 & 20.6 & 19.2 & & 19.2 & 19.2 & \\
\hline Exports & 48.8 & 44.6 & 45.8 & 43.0 & & & 40.5 & 39.7 & 38.5 & 40.3 & 41.1 & 41.7 & & 41.7 & 41.7 & \\
\hline Imports & 58.8 & 65.7 & 66.5 & 66.6 & & & 66.9 & 65.4 & 60.9 & 62.7 & 61.7 & 60.9 & & 60.9 & 60.9 & \\
\hline Net current transfers (negative = inflow) & -3.3 & -3.4 & -4.1 & -4.1 & -4.0 & 0.5 & -4.8 & -4.8 & -4.8 & -4.8 & -4.8 & -4.4 & & -4.4 & -4.4 & -4.4 \\
\hline Of which: Official & 0.2 & 0.1 & 0.1 & -1.2 & & & -1.1 & -1.0 & -1.0 & -0.9 & -0.9 & -0.8 & & -0.8 & -0.8 & \\
\hline Other current account flows (negative = net inflow) & 3.6 & 5.6 & 4.3 & 2.7 & & & 3.4 & 3.6 & 3.7 & 3.7 & 3.8 & 3.7 & & 3.6 & 3.9 & \\
\hline Net FDI (negative = inflow) & -9.3 & -15.9 & -9.2 & -19.1 & -16.3 & 8.7 & -18.0 & -18.0 & -15.4 & -15.4 & -14.7 & -14.7 & & -14.7 & -14.7 & -14.7 \\
\hline Endogenous debt dynamics $3 /$ & -1.4 & -2.5 & -1.1 & -3.8 & & & -0.9 & 0.8 & 0.7 & 0.6 & 0.7 & 0.8 & & 0.6 & 0.3 & \\
\hline Contribution from nominal interest rate & 1.2 & 1.4 & 1.8 & 2.3 & & & 1.9 & 2.3 & 2.2 & 2.2 & 2.2 & 2.2 & & 2.2 & 1.9 & \\
\hline Contribution from real GDP growth & -1.5 & -3.2 & -1.3 & -3.3 & & & -2.9 & -1.5 & -1.5 & -1.6 & -1.4 & -1.4 & & -1.6 & -1.6 & \\
\hline Contribution from price and exchange rate changes & -1.2 & -0.7 & -1.6 & -2.7 & & & & & & & & & & & & \\
\hline Residual (3-4) 4l & -2.1 & -2.6 & -10.2 & -5.0 & & & -14.7 & 0.2 & 0.3 & 0.3 & 0.4 & -0.2 & & -0.1 & -0.1 & \\
\hline Of which: Exceptional financing & 0.0 & 0.0 & 0.0 & 0.0 & & & 0.0 & 0.0 & 0.0 & 0.0 & 0.0 & 0.0 & & 0.0 & 0.0 & \\
\hline NPV of external debt $5 /$ & $\ldots$ & $\ldots$ & $\ldots$ & 38.9 & & & 30.9 & 31.7 & 30.7 & 31.1 & 32.6 & 33.3 & & 39.3 & 41.6 & \\
\hline In percent of exports & $\ldots$ & $\ldots$ & $\ldots$ & 90.4 & & & 76.2 & 79.8 & 79.8 & 77.3 & 79.3 & 79.7 & & 94.2 & 99.6 & \\
\hline NPV of PPG external debt & ... & ... & $\ldots$ & 38.9 & & & 30.9 & 31.7 & 30.7 & 31.1 & 32.6 & 33.3 & & 39.3 & 41.6 & \\
\hline In percent of exports & ... & ... & ... & 90.4 & & & 76.2 & 79.8 & 79.8 & 77.3 & 79.3 & 79.7 & & 94.2 & 99.6 & \\
\hline In percent of government revenues & & ... & $\ldots$ & 117.7 & & & 95.8 & 93.8 & 95.0 & 98.4 & 103.3 & 106.5 & & 125.9 & 133.2 & \\
\hline Debt service-to-exports ratio (in percent) & 6.5 & 10.0 & 11.0 & 13.0 & & & 12.4 & 13.7 & 14.4 & 13.5 & 12.7 & 12.0 & & 12.9 & 12.1 & \\
\hline PPG debt service-to-exports ratio (in percent) & 6.5 & 10.0 & 11.0 & 13.0 & & & 12.4 & 13.7 & 14.4 & 13.5 & 12.7 & 12.0 & & 12.9 & 12.1 & \\
\hline PPG debt service-to-revenue ratio (in percent) & 9.4 & 14.2 & 16.4 & 16.9 & & & 15.6 & 16.1 & 17.2 & 17.1 & 16.5 & 16.0 & & 17.2 & 16.2 & \\
\hline Total gross financing need (millions of U.S. dollars) & 15.0 & 49.7 & 73.4 & 42.3 & & & 66.5 & 73.1 & 76.8 & 84.4 & 81.3 & 75.9 & & 120.0 & 276.5 & \\
\hline Noninterest current account deficit that stabilizes debt ratio & 12.8 & 21.0 & 20.5 & 27.9 & & & 40.2 & 23.6 & 21.9 & 20.8 & 17.9 & 17.6 & & 18.0 & 18.4 & \\
\hline \multicolumn{17}{|l|}{ Key macroeconomic assumptions } \\
\hline Real GDP growth (in percent) & 3.2 & 6.8 & 2.6 & 6.9 & 3.8 & 2.3 & 6.7 & 5.0 & 4.8 & 5.2 & 4.7 & 4.3 & 5.1 & 4.3 & 4.3 & 4.3 \\
\hline GDP deflator in U.S. dollar terms (change in percent) & 2.5 & 1.4 & 3.0 & 5.3 & 2.1 & 1.7 & 4.9 & 5.4 & 5.2 & 4.5 & 4.4 & 3.9 & 4.7 & 4.3 & 4.3 & 4.3 \\
\hline Effective interest rate (percent) $6 /$ & 2.7 & 2.9 & 3.5 & 4.7 & 2.8 & 1.9 & 4.5 & 7.7 & 7.1 & 7.2 & 7.1 & 6.6 & 6.7 & 6.0 & 5.0 & 5.9 \\
\hline Growth of exports of goods and services (U.S. dollar terms, in & 1.4 & 6.7 & 8.7 & 5.7 & 4.4 & 4.7 & 5.3 & 8.5 & 6.8 & 14.9 & 11.5 & 10.1 & 9.5 & 8.7 & 8.7 & 8.7 \\
\hline Growth of imports of goods and services (U.S. dollar terms, in percent) & 3.3 & 12.8 & 7.0 & 12.7 & 5.7 & 11.2 & 12.5 & 8.1 & 2.6 & 13.2 & 7.5 & 7.0 & 8.5 & 8.7 & 8.7 & 8.7 \\
\hline Grant element of new public sector borrowing (in percent) & & & & & ... & $\ldots$ & 10.9 & 6.7 & 14.0 & 10.9 & 10.9 & 10.9 & 10.7 & 10.9 & 10.9 & 10.9 \\
\hline Aid flows (in billions of U.S. dollars) 71 & 10.5 & 7.7 & 17.2 & 26.1 & & & 116.5 & 74.3 & 90.4 & 82.1 & 44.1 & 33.1 & & 50.3 & 116.3 & \\
\hline Of which: Grants & 3.9 & 2.8 & 6.4 & 9.7 & & & 22.56 & 27.5 & 33.5 & 30.4 & 16.3 & 12.2 & & 18.6 & 43.1 & \\
\hline Of which: Concessional loans & 0.0 & 0.0 & 0.0 & 0.0 & & & 0.0 & 0.0 & 0.0 & 0.0 & 0.0 & 0.0 & & 0.0 & 0.0 & \\
\hline Grant-equivalent financing (in percent of GDP) 8/ & 1.1 & 0.7 & 1.5 & 2.0 & & & 4.3 & 5.0 & 5.8 & 4.9 & 2.8 & 2.1 & & 2.1 & 2.1 & 2.1 \\
\hline Grant-equivalent financing (in percent of external financing) $8 /$ & $\ldots$ & & $\ldots$ & $\ldots$ & & & 68.2 & 42.7 & 53.3 & 44.3 & 29.6 & 27.0 & & 26.2 & 26.2 & 26.2 \\
\hline \multicolumn{17}{|l|}{ Memorandum ite } \\
\hline Nominal GDP (millions of U.S. dollars) & 365.2 & 414.0 & 437.6 & 492.7 & & & 551.4 & 609.8 & 671.8 & 738.3 & 807.1 & 874.8 & & $1,330.5$ & $3,077.9$ & \\
\hline (NPVt-NPVt-1)/GDPt-1 (in percent) & & & & & & & -4.4 & 4.2 & 2.2 & 3.5 & 4.5 & 3.5 & 2.2 & 4.8 & 3.6 & 4.0 \\
\hline
\end{tabular}

and the Grenadines authorities; and Fund staff simulations.

1/ Historical averages and standard deviations are generally derived over the past 10 years, subject to data availability.

3/ Derived as $[\mathrm{r}-\mathrm{g}-\mathrm{r}(1+\mathrm{g})] /(1+\mathrm{g}+\mathrm{r}+\mathrm{gr})$ times previous period debt ratio, with $\mathrm{r}=$ nominal interest rate; $\mathrm{g}=$ real GDP growth rate, and $\mathrm{r}=\mathrm{growth}$ rate of GDP deflator in U.S. dollar terms.

$4 /$ Includes the Ottley Hall debt write-off for 2007; changes in gross foreign assets; and valuation adjustments. For projections also includes contribution from price changes.

5/Assumes that NPV of private sector debt is equivalent to its face value.

6/ Current-year interest payments divided by previous peitod

8/ Grant-equivalent financing includes grants provided directly to the government and through new borrowing (difference between the face value and the NPV of new debt). 
Table 4. St. Vincent and the Grenadines: Sensitivity Analyses for Key Indicators of Public and Publicly Guaranteed External Debt, 2007-27 (In percent)

Projections

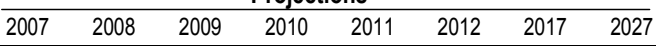

\section{NPV of debt-to-GDP ratio}

Baseline

A. Alternative Scenarios

A1. Key variables at their historical averages in 2008-27 1/

A2. New public sector loans on less favorable terms in 2008-27 2/

\section{B. Bound Tests}

B1. Real GDP growth at historical average minus one standard deviation in 2008-09

B2. Export value growth at historical average minus one standard deviation in 2008-09 3/

B3. U.S. dollar GDP deflator at historical average minus one standard deviation in 2008-09

B4. Net nondebt creating flows at historical average minus one standard deviation in 2008-09 4/

B5. Combination of B1-B4 using one-half standard deviation shocks

B6. One-time 30 percent nominal depreciation relative to the baseline in 20085

$\begin{array}{llllllll}31 & 32 & 31 & 31 & 33 & 33 & 39 & 42 \\ & & & & & & & \\ 31 & 33 & 34 & 36 & 37 & 39 & 49 & 66 \\ 31 & 32 & 31 & 32 & 34 & 35 & 41 & 46 \\ & & & & & & & \\ 35 & 42 & 48 & 53 & 56 & 58 & 57 & 58 \\ 35 & 44 & 54 & 58 & 61 & 62 & 54 & 55 \\ 35 & 43 & 49 & 54 & 58 & 59 & 59 & 60 \\ 35 & 52 & 64 & 68 & 70 & 71 & 55 & 55 \\ 35 & 47 & 61 & 66 & 70 & 71 & 62 & 62 \\ 35 & 57 & 63 & 69 & 74 & 76 & 75 & 76\end{array}$

\section{NPV of debt-to-exports ratio}

\section{Baseline}

\section{A. Alternative Scenarios}

A1. Key variables at their historical averages in 2007-26 1/

A2. New public sector loans on less favorable terms in 2007-26 2

$\begin{array}{rrrrrrrr}76 & 80 & 80 & 77 & 79 & 80 & 94 & 100 \\ & & & & & & & \\ 76 & 82 & 89 & 89 & 91 & 92 & 117 & 158 \\ 76 & 81 & 82 & 80 & 83 & 84 & 97 & 110 \\ & & & & & & & \\ 87 & 102 & 117 & 123 & 129 & 129 & 128 & 131 \\ 87 & 122 & 168 & 172 & 178 & 178 & 155 & 156 \\ 87 & 102 & 117 & 123 & 129 & 129 & 128 & 131 \\ 87 & 130 & 166 & 168 & 171 & 170 & 133 & 131 \\ 87 & 120 & 160 & 164 & 170 & 170 & 148 & 148 \\ 87 & 102 & 117 & 123 & 129 & 129 & 128 & 131\end{array}$

\section{Debt service-to-exports ratio}

Baseline

$\begin{array}{rrrrrrrr}12 & 14 & 14 & 13 & 13 & 12 & 13 & 12 \\ & & & & & & & \\ 12 & 14 & 16 & 15 & 15 & 14 & 16 & 19 \\ 12 & 14 & 12 & 11 & 11 & 10 & 9 & 12\end{array}$

A2. New public sector loans on less favorable terms in 2008-27 2/

\section{B. Bound Tests}

B1. Real GDP growth at historical average minus one standard deviation in 2008-09

B2. Export value growth at historical average minus one standard deviation in 2008-09 3/

B3. U.S. dollar GDP deflator at historical average minus one standard deviation in 2008-09

B4. Net nondebt creating flows at historical average minus one standard deviation in 2008-09 4/

B5. Combination of B1-B4 using one-half standard deviation shocks

B6. One-time 30 percent nominal depreciation relative to the baseline in $20085 /$

$\begin{array}{llllllll}12 & 14 & 15 & 15 & 15 & 16 & 20 & 17 \\ 12 & 16 & 19 & 19 & 18 & 20 & 25 & 21 \\ 12 & 14 & 15 & 15 & 15 & 16 & 20 & 17 \\ 12 & 14 & 17 & 17 & 16 & 18 & 21 & 17 \\ 12 & 15 & 18 & 18 & 18 & 19 & 24 & 20 \\ 12 & 14 & 15 & 15 & 15 & 16 & 20 & 17\end{array}$

Source: St. Vincent and the Grenadines authorities; and Fund staff projections and simulations.

1/ Variables include real GDP growth, growth of GDP deflator (in U.S. dollar terms), noninterest current account in percent of GDP, and nondebt creating flows

2/ Assumes that the interest rate on new borrowing is by 2 percentage points higher than in the baseline, while grace and maturity periods are the same as in the baseline.

3 / Exports values are assumed to remain permanently at the lower level, but the current account as a share of GDP is assumed to return

to its baseline level after the shock (implicitly assuming an offsetting adjustment in import levels).

$4 /$ Includes official and private transfers and FDI.

5/ Depreciation is defined as percentage decline in dollar/local currency rate, such that it never exceeds 100 percent. 
Figure 1. St. Vincent and the Grenadines: Indicators of Public Debt Under Alternative Scenarios, 2007-27 1/
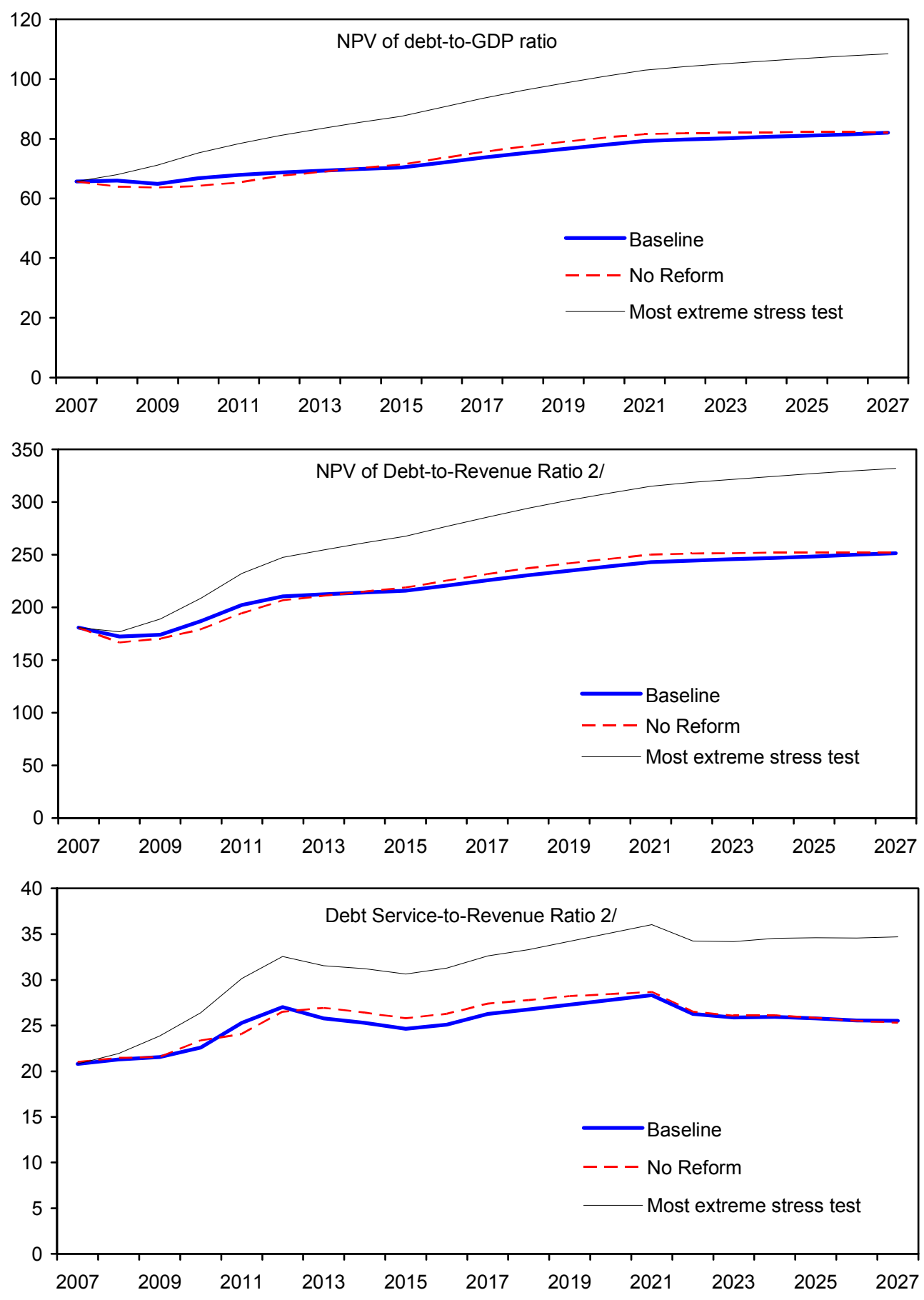

Source: Fund staff projections and simulations.

$1 /$ Most extreme stress test is test that yields highest ratio in 2017.

2/ Revenue including grants. 
Figure 2. St. Vincent and the Grenadines: Indicators of Public External Debt Under Alternative Scenarios, 2007-27
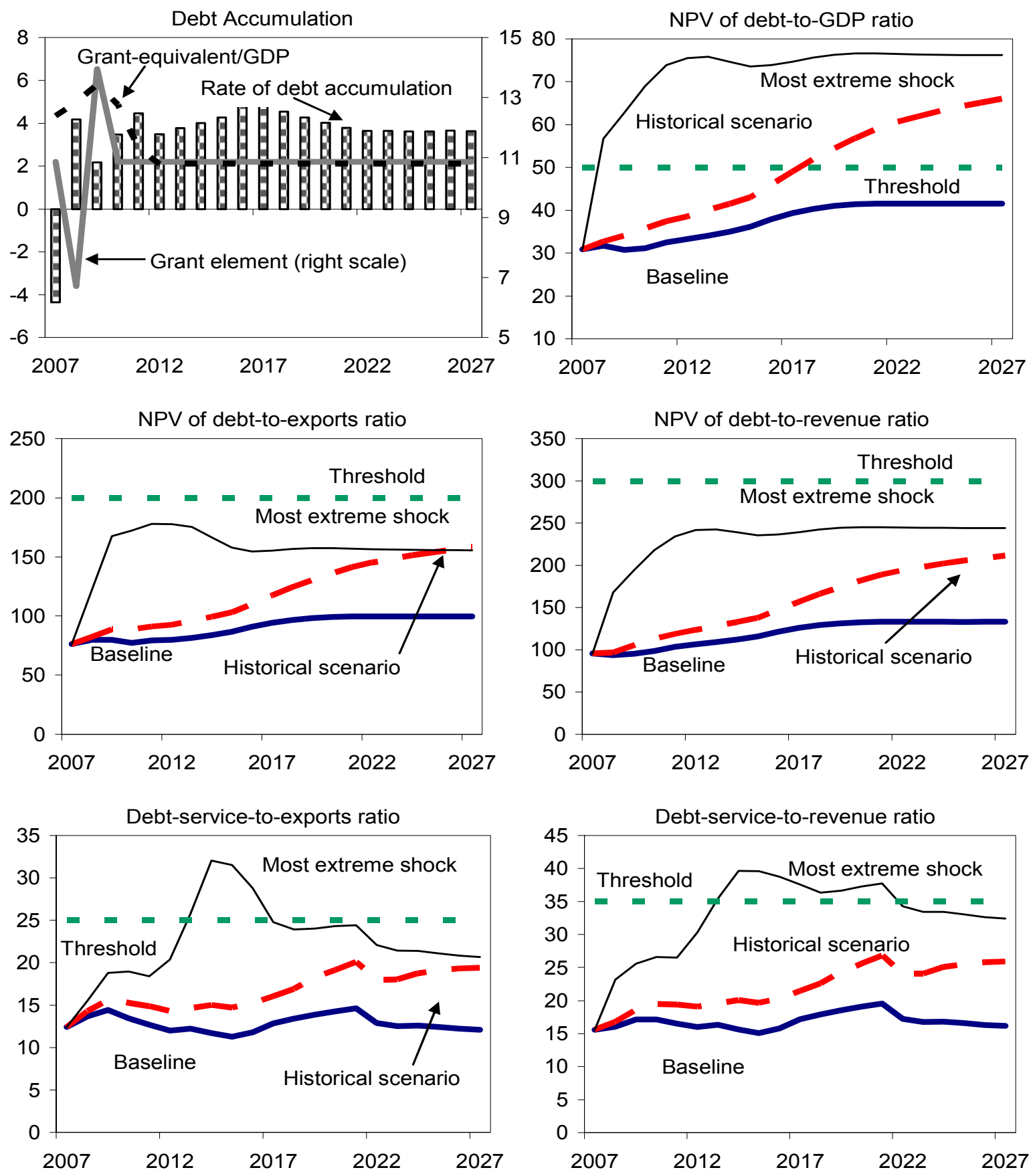

Source: Fund staff projections and simulations. 


\section{Statement by the IMF Staff Representative February 4, 2008}

1. The following information has become available since the staff report was issued. The thrust of the staff appraisal remains unchanged.

\section{The 2008 Budget announced some changes to the VAT rate and exemption} structure. The VAT rate for some tourism-related services was reduced from 15 to 10 percent, yachting was exempted, and a number of additional food and personal items were zero-rated. The authorities estimate that these changes will cost around 0.4 percent of GDP annually; an upcoming FAD technical assistance mission will refine the estimates.

\section{The 2008 Budget is likely to yield some fiscal consolidation, assuming capital} spending implementation and grant receipts are at historical rates. Total revenue (including grants) is expected to increase by $1 \frac{1}{2}$ percent of GDP relative to the 2007 projected outturn, driven by a sharp rise in external grants. Current revenues remain constant (as a share of GDP) as an increase in fuel prices largely offsets a reduction in the corporate income tax rate from $37 \frac{1}{2}$ to 35 percent. Expenditure comes down marginally, as a reduction in capital spending more than offsets an increase in current spending. Staff estimates that the central government overall deficit for 2008 will narrow to around $2 \frac{1}{2}$ percent of GDP; close to the staff's active scenario, albeit driven more by the increase in grants than by expenditure reduction and current revenue increases. A sustained deficit reduction would require continued expenditure restraint as grants are likely to revert to their long-run average.

\section{Increases in the contribution rates for the National Insurance Services (NIS)} were announced in the budget. The government signaled its commitment to further social security reforms, including gradual increases in the retirement age; options for reforming the public service pension system are also under consideration. These steps are in line with recent FAD technical assistance recommendations. 
St. Vincent and the Grenadines: Summary of Central Government Operations, 2005-08

(In percent of GDP, unless otherwise stated)

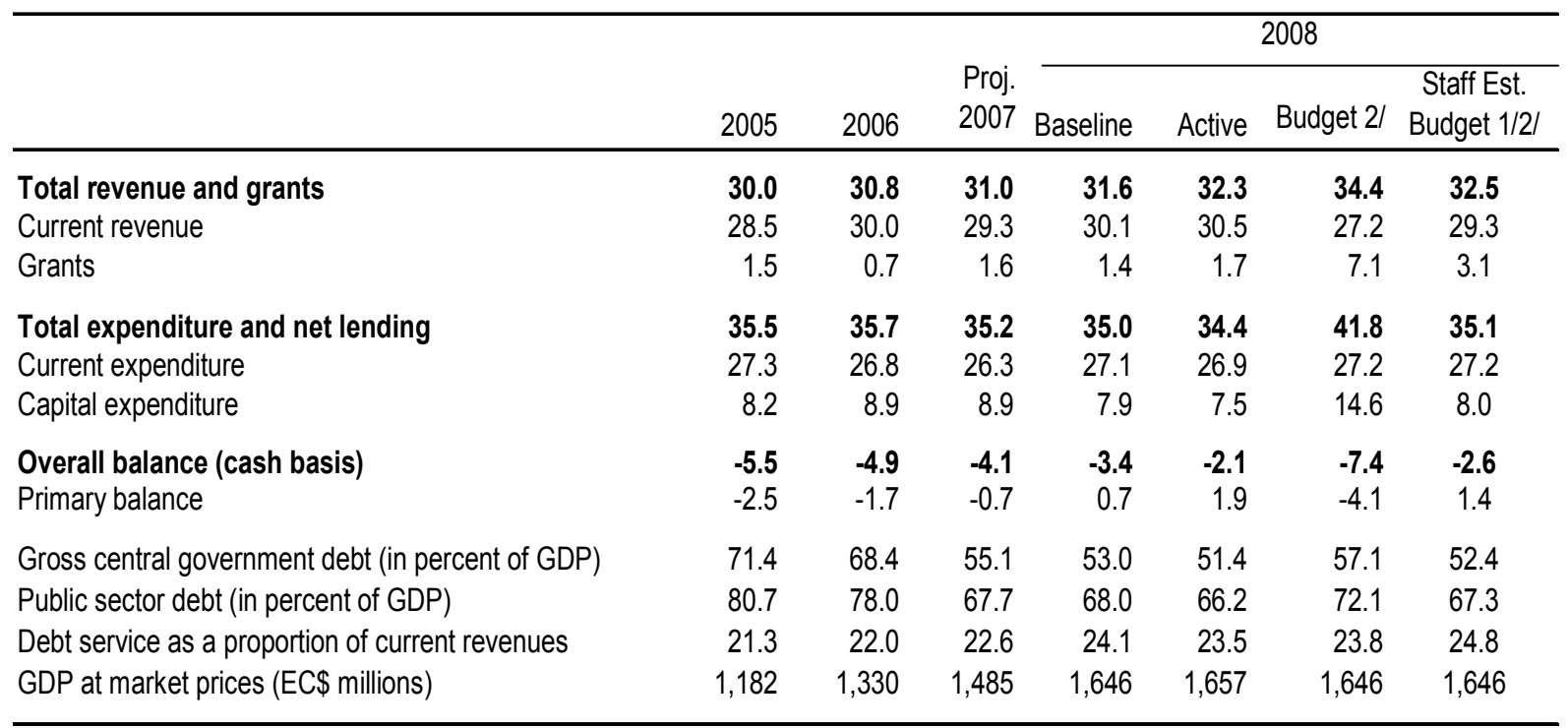

Sources: St. Vincent and the Grenadines authorities; and Fund staff estimates and projections.

$1 /$ As in the approved budget, except for capital expenditure and grants, for which an execution and materialization rate of 55 and 44 percent, respectively, is assumed, in line with historical implementation and materialization rates.

2/Current revenues for 2008, in both the budget and staff estimate columns, follow the budget assumption of 12 percent growth from the end-2007 current revenues. The end-2007 base used in the budget is an underestimate, while the staff estimate column uses the latest government projection for end-2007 current revenues. 


\section{INTERNATIONAL MONETARY FUND}

EXTERNAL

Public Information Notice

RELATIONS

DEPARTMENT

Public Information Notice (PIN) No. 08/33

FOR IMMEDIATE RELEASE

International Monetary Fund

March 13, 2008

$70019^{\text {th }}$ Street, NW

Washington, D. C. 20431 USA

\section{IMF Executive Board Concludes 2007 Article IV Consultation with St. Vincent and the Grenadines}

On February 4, 2008, the Executive Board of the International Monetary Fund (IMF) concluded the Article IV consultation with St. Vincent and the Grenadines. ${ }^{1}$

\section{Background}

The economy is enjoying its second year of vigorous economic growth. Output grew at close to 7 percent in 2006, the highest in the last decade and well above potential (estimated at $41 / 4$ percent). Economic activity was sustained by construction and government services. In 2007 growth remained strong, despite disappointing tourism arrivals, due largely to tourismrelated investments and government capital expenditure. Inflation has risen, mostly reflecting the higher international oil and food prices, and is expected to reach 8.2 percent by end-2007.

The current account deficit is expected to remain high in 2007-08 on account of higher imports for various tourism-related projects, and capital spending by the government. Credit to the private sector expanded by 141/4 percent in 2006, attributable to the Cricket World Cup (CWC) and tourism-related activities.

Financial sector indicators have strengthened, but balance sheet vulnerabilities remain. Asset quality and capital adequacy have improved, with unsatisfactory assets (non-performing loans) down to 3 percent of total loans, well below the Eastern Caribbean Central Bank's target of 5

\footnotetext{
${ }^{1}$ Under Article IV of the IMF's Articles of Agreement, the IMF holds bilateral discussions with members, usually every year. A staff team visits the country, collects economic and financial information, and discusses with officials the country's economic developments and policies. On return to headquarters, the staff prepares a report, which forms the basis for discussion by the Executive Board. At the conclusion of the discussion, the Managing Director, as Chairman of the Board, summarizes the views of Executive Directors, and this summary is transmitted to the country's authorities.
} 
percent. Increasing competition from nonbank financial institutions and recent rapid credit growth could result in weaknesses in loan classification and problem loans down the road, especially in the event of a large adverse shock. An update of a 2004 Anti-Money Laundering/Combating the Financing of Terrorism (AML/CFT) assessment will take place in early 2009 , at the request of the authorities.

The fiscal position has strengthened. The primary deficit has narrowed by around 2 percent of GDP during 2005-07 reflecting both higher revenues and current spending restraint. Revenues benefited from the growth dividend (higher stamp taxes related to land sales), more frequent pass-through of oil prices, as well as the introduction of a VAT in May 2007. Wage restraint helped contain spending despite an increase in capital expenditure.

An agreement with Italy to write-off a debt obligation has reduced St. Vincent and the Grenadines' public debt stock by about 10 percent of GDP. The loan had been serviced by the Italian export agency, due to perceived malfeasance by the private builder-operator. The writeoff, formalized in October 2007, will lower the debt to-GDP ratio to around 68 percent by end2007.

\section{Executive Board Assessment}

Directors welcomed St. Vincent and the Grenadines' recent strong macroeconomic performance, marked by robust economic growth, fiscal consolidation, and declining debt levels. Directors noted that the potential upside risks to inflation, the high current account deficit, and the still-high public debt require continued efforts to maintain macroeconomic stability. They welcomed the authorities' commitment to diversifying the economy, further developing the tourist industry, lowering the cost of doing business, and reducing the vulnerability to economic shocks to address these medium-term challenges.

Directors stressed that continued fiscal consolidation is needed to lower the public debt-to-GDP ratio, and create room to raise social spending. They welcomed the recent introduction of a value-added tax (VAT) and encouraged the authorities to resist pressures to change the VAT rates and the exemption structure. They supported the early introduction of market valuationbased property taxes, the reduction of tax concessions, and the timely pass-through of international oil price changes. Spending restraint will also be important, particularly through control of the wage bill and prioritization of capital expenditure.

Directors noted the authorities' plan to accelerate investment in tourism-related infrastructure, in particular the ongoing construction of a new international airport. While the higher investment is expected to raise the economy's growth potential and planned land sales could help to fill the financing gap, Directors encouraged the authorities to undertake an updated study of the financing structure, and to seek additional grant and concessional financing to contain the potential impact on the country's debt position.

While the real effective exchange rate is broadly in line with fundamentals, Directors considered that maintaining St. Vincent and the Grenadines' external competitiveness will require continued 
fiscal consolidation along with growth-enhancing reforms. They expected the current account deficit, which is mainly financed by grants and foreign direct investment, to decline over the medium term in line with the fall in infrastructure and tourism investment.

Directors welcomed the authorities' ongoing efforts to reform the National Insurance Services, including through increases in the contribution rate, and encouraged the authorities to integrate the civil service pension system with the National Insurance Services. Directors also welcomed the amendments to the Banking Act and encouraged the establishment of a single regulatory unit to supervise non-bank financial institutions.

Directors welcomed the authorities' efforts to improve the quality of statistics, and encouraged the authorities' further efforts to improve the coverage and timeliness of data.

Public Information Notices (PINs) form part of the IMF's efforts to promote transparency of the IMF's views and analysis of economic developments and policies. With the consent of the country (or countries) concerned, PINs are issued after Executive Board discussions of Article IV consultations with member countries, of its surveillance of developments at the regional level, of post-program monitoring, and of ex post assessments of member countries with longer-term program engagements. PINs are also issued after Executive Board discussions of general policy matters, unless otherwise decided by the Executive Board in a particular case. 
St. Vincent and the Grenadines: Selected Economic Indicators, 2003-08

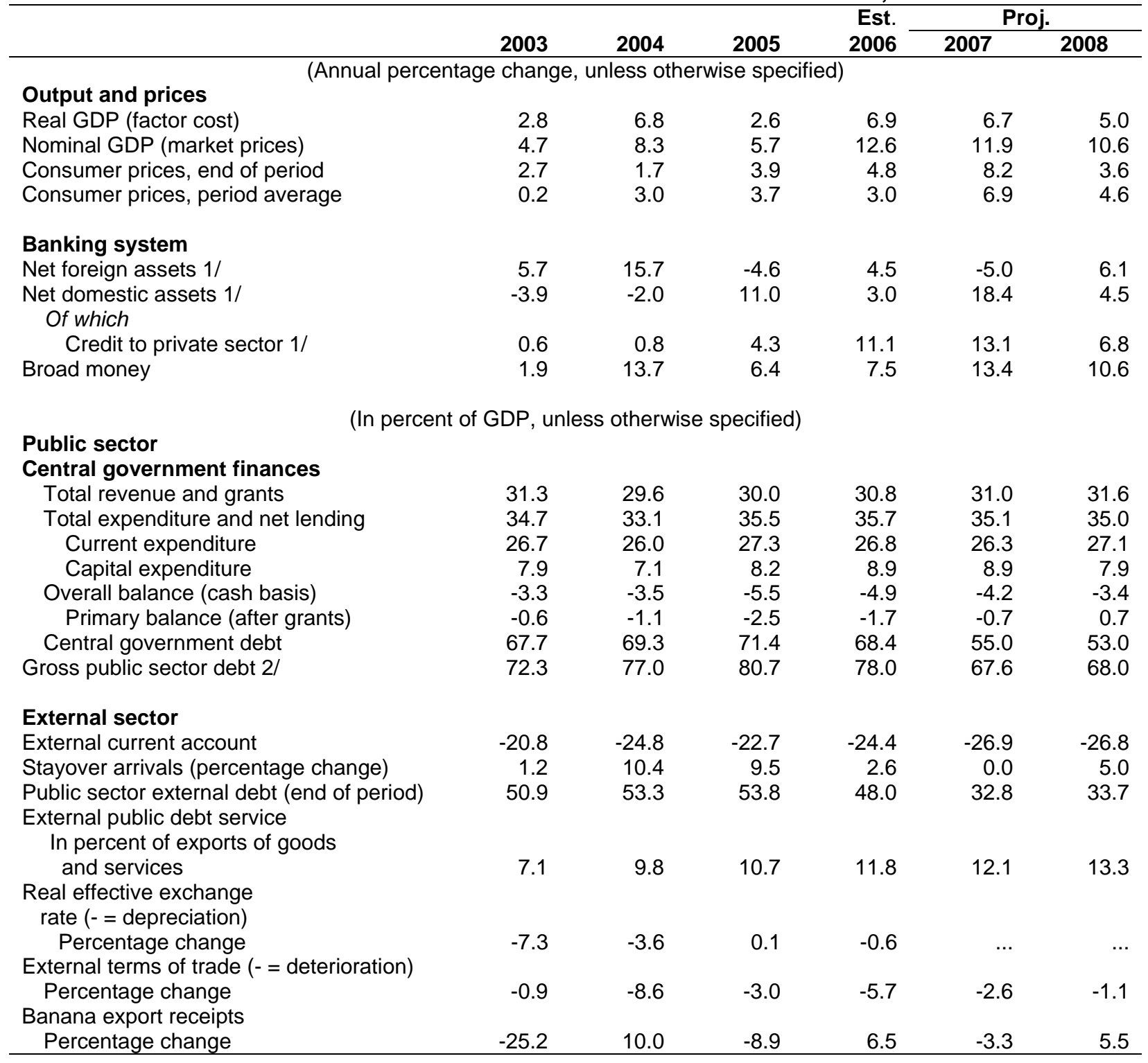

Sources: St. Vincent and the Grenadines authorities; ECCB; and IMF staff estimates and projections.

$1 /$ Annual changes relative to the stock of broad money at the beginning of the period.

2/ Net of liabilities to the NIS. 


\section{Statement by Jonathan Fried, Executive Director for St. Vincent and the Grenadines and Peter Charleton, Alernate Executive Director February 4, 2008}

The authorities of St. Vincent and the Grenadines (SVG) express their thanks to the staff for a very productive dialogue and a fair and well-balanced report. They also wish to acknowledge the valuable technical assistance provided in the context of introducing VAT.

This discussion is being held in the context of the overall ECCU regional surveillance discussion and the issues raised in the ECCU Buff are pertinent to SVG. Within the ECCU, St. Vincent is one of the lower income, less developed economies. It has a large poor rural population, suffers from difficult and expensive access and has been disproportionately impacted by the decline of the banana industry. Although the Grenadines enjoy a high-end tourism niche, the fragile environment effectively precludes large-scale tourism. St. Vincent, with the vast bulk of the population, has been an agriculturally-based economy and is only now moving towards a tourism and services-based economy. As is the case with the other East Caribbean islands, SVG is particularly vulnerable to the global economic developments and unpredictable weather-related shocks. It is against this background that the authorities are seeking to re-orient the economy.

\section{Economic Performance}

Economic performance over the past few years has been quite good, with growth of around 7 percent in both 2006 and 2007 and prospects for the future are encouraging. The decline of the banana industry has been offset by strong growth in construction, both in relation to the 2007 Cricket World Cup and to some major hotel projects. Major challenges remain, however, in tackling of rural poverty and enhancing the skills of the younger generation.

The spike of inflation is of particular concern to the authorities and they have few instruments to combat it. The strong peg to the US dollar has always provided monetary stability, but the combination of the pass-through of high oil prices, the introduction of VAT, rising global food prices (which have a large weight in the CPI), and the weak US dollar combined to push inflation to above 8 percent at the end of 2007. The authorities have refrained from taking exceptional measures that would have entailed fiscal costs and have remained firm on public sector pay. Inflation is expected to ease in 2008 but living standards are being impacted.

While the current external deficit, at 27 percent of GDP, appears extremely large, it reflects imports for large tourism developments and are financed by FDI. The deficit does not reflect exchange rate misalignment or overvaluation of the currency and it does not represent a threat to the currency peg.

\section{Fiscal Policy}

SVG's fiscal record has been relatively good over time. The cost of providing infrastructure and public services across a multi-island country with a small population remains a major 
challenge. The progressive loss of traditional donor support and weather-related disasters has added to fiscal pressures. At 68 percent of GDP, the debt ratio is not inordinately high and the ECCB benchmark of 60 percent is clearly achievable. But the more immediate goal of the authorities is to reduce debt-service costs which tend to crowd-out much needed social expenditure.

Over the past few years, the authorities have tightened fiscal policy with action on both the revenue and expenditure sides. The introduction of VAT in May 2007 was effected very smoothly and the revenue results have been positive. While the 2008 budget contained some adjustments to the VAT regime, its integrity has been maintained and the authorities are determined and confident that they will not be forced into unwarranted concessions. While the authorities have not adopted a fully automatic pricing mechanism for fuel products, oil price increases are passed through on a regular basis and the fiscal burden has been eliminated. Going forward, the authorities are working on a market valuation-based property tax, which should further enhance revenue. On the expenditure side the authorities have successfully reined-in public sector pay and will continue to exercise restraint. They are also bringing forward parametric changes to the pension regime. National Insurance Service (NIS) contribution rates were increased in the 2008 budget and the pension age is being gradually increased. Overall, the 2008 budget entails significant fiscal consolidation broadly consistent with the staff's active scenario.

\section{The Airport}

The dominant issue in the discussion with the staff affecting fiscal and growth prospects is the construction of an international airport. The simple reality is that the two least developed ECCU countries - SVG and Dominica - are those with airports not capable of taking jet aircraft or night landings. Access to SVG is thus more difficult and expensive than the neighboring islands and is a huge impediment to development of the tourist industry. On the other hand, the cost of construction of even a modest airport is as high as 40 percent of GDP, given the very difficult topography of the island and the small size of the population. The authorities are executing the development of the new airport with help from non-traditional donors in a manner which should not lead to an increase in the public debt. Initially, the authorities have to incur debt to buy the land for the airport, but they own significant other lands which, after infrastructural investment to enhance its value, will be sold to repay debt. Debt financing will thus be of a bridging nature and will not add to the debt ratio over time. The authorities do acknowledge however that the project is not without risks; understand the staff's emphasis on the need to maintain tight fiscal discipline, and appreciate the various scenarios postulated in the debt sustainability paper. The baseline scenario is for little change in the debt ratio and the debt would remain sustainable. The staff also postulates an active scenario of a 4 percent of GDP primary surplus. While such a target is probably overly ambitious, the authorities acknowledge that it provides useful policy guidance.

\section{Financial Sector Issues}

The financial sector in SVG remains sound and prudential indicators have generally strengthened. Asset quality and capital ratios have improved and NPLs declined. The 
authorities note the staff's caution on a potential deterioration of credit quality in the recent period of rapid credit growth but, a priori, there is no reason to expect significant problems. Supervision has progressively improved. The regulatory powers of the ECCB were strengthened in 2006 and the authorities are working toward establishment of a Single Regulatory Unit (SRU) for non-banks. Interestingly, the financial sector turbulence that has affected much larger and more sophisticated jurisdictions has had no discernable impact on the Caribbean financial sector to date. 